\title{
Importance of the traditional land-use and land-tenure systems of Waraka, Seram Island, Maluku
}





\section{Importance of the traditional land-use and land-tenure systems of Waraka, Seram Island, Maluku}


Working Paper 144

(c) 2014 Center for International Forestry Research

(c) (i) Content in this publication is licensed under a Creative Commons Attribution-NonCommercialNoDerivs 3.0 Unported License http://creativecommons.org/licenses/by-nc-nd/3.0/

Ducos L. 2014. Importance of the traditional land-use and land-tenure systems of Waraka, Seram Island, Maluku. Working Paper 144. Bogor, Indonesia: CIFOR.

Cover photo by Laure Ducos.

Waraka, Seram Island, Maluku, Indonesia

\section{CIFOR}

Jl. CIFOR, Situ Gede

Bogor Barat 16115

Indonesia

$\mathrm{T}+62(251) 8622-622$

$\mathrm{F}+62(251) 8622-100$

E cifor@cgiar.org

\section{cifor.org}

We would like to thank all donors who supported this research through their contributions to the CGIAR Fund. For a list of Fund donors please see: https://www.cgiarfund.org/FundDonors

Any views expressed in this publication are those of the authors. They do not necessarily represent the views of CIFOR, the editors, the authors' institutions, the financial sponsors or the reviewers. 


\section{Contents}

Lists of figures and tables $\quad$ iv

Summary $\quad$ v

Acknowledgments $\quad$ vi

List of abbreviations vii

1 Introduction 1

2 Materials and methods $\quad 3$

2.1 Field site 3

2.2 Theoretical framework 3

2.3 Literature review $\quad 5$

2.4 Field data collection $\quad 5$

$\begin{array}{ll}2.5 & \text { Data analysis }\end{array}$

3 Results $\quad 8$

3.1 Land tenure system and rights in Indonesia $\quad 8$

3.2 Land-use planning in Indonesia 9

3.3 Land-use planning and tenure in Waraka: Two territories with two structures of governance 11

3.4 Governmental spatial planning in Waraka’s adat territory 14

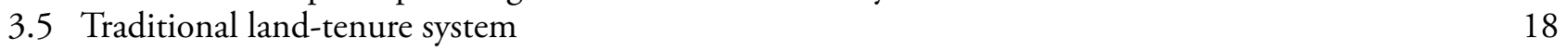

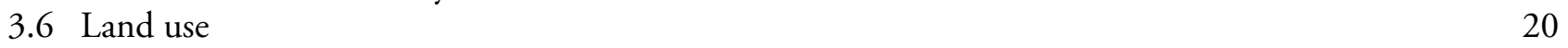

$\begin{array}{ll}3.7 & \text { Actors' network and factors of changes } \\ \end{array}$

4 Discussion $\quad 33$

4.1 Land-tenure security 33

4.2 How to reconcile socioeconomic development and environmental preservation 37

4.3 Practical difficulties and limitations of the study 40

5 Conclusion $\quad 41$

6 References $\quad 42$

Appendices

1 Questionnaire for FGD 45

2 Full list of the semi-structured interviews used for the study 48

3 Fact sheet: Waraka's home-gardens 49

4 Fact sheet: Waraka’s food crop fields $\quad 50$

5 Non-exhaustive list of vegetables that can be found in Waraka farmers' food crop fields 51

6 Coconut and cocoa production of Waraka's community 52

7 The remaining production of rubber in Waraka 53

8 Mixed tree gardens of Waraka: Dusun in the lowlands 54

9 Non-exhaustive list of species found in the traditional mixed forest gardens of Waraka's community 55

10 Sketch profile of the first $7 \mathrm{~km}$ of Waraka territory 56

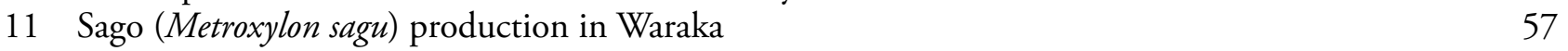

12 Albisia priangan Lestari (APL): Private logging company 58

13 The PTP Nusantara XIV: A state-owned cocoa, coconut and rubber company 60 


\section{Lists of figures and tables}

\section{Figures}

1 Indonesia and CoLUPSIA sites in Kalimantan and Maluku. 2

2 Seram Island, Moluccas. 3

3 From left to right: Houses of Waraka, the raja with the saniri negeri and a view of the coast. 4

4 Institutional analysis and development framework applied to land-tenure security. 4

5 Participatory mapping during a focus-group discussion with men under 35 years old (left) and with Yan (CoLUPSIA partner), members of the saniri negeri and the raja at Waraka, June 2013.

6 Spatial planning system in Indonesia. $\quad 10$

7 Map of adat and administrative territories. $\quad 13$

8 Adat structure of Waraka. $\quad 14$

9 Adminsitrative structure of Waraka.

10 RTRW-K (provincial spatial plan) of Center Moluccas 2005-2028. 15

11 Forest land category allocation map for Central Seram (SK 415/Kpts-II/1999). 15

12 Simplified map of land use planning in Waraka’s adat territory. $\quad 17$

13 Prospecting material for local mining in Waraka. 18

14 Land-use map: part of Waraka territory.

15 Slash and burn cultivation in Waraka, from forests to dusun. 24

16 Left: Old aong, at the top of a hill; Right: Aong that will be planted with more fruit trees soon. 24

17 Land-use map - part of Waraka's adat territory. 28

18 Map of the commercial plantations of PTPN XIV on part of Waraka's administrative territory. $\quad 29$

19 Negotiations between the community of Waraka and PTPN XIV. Left: The raja sits between the head of adat and the company's director. Right: Overview of the meeting, with members of the community in traditional clothes and members of the company in front. 36

20 (a) Logging concession (HPH) overlayed on the Digital Elevation Model based on CoLUPSIA data; (b) Zonation for land allocation using 1:50,000 scale topographic maps by the CoLUPSIA project. 39

\section{Tables}

1 Main institutions involved in land-use planning policies in Maluku. $\quad 11$

2 Mean incomes for staple and non-staple food from the Waraka food crop fields. 20

3 Mean income per household for each main crop in Waraka. $\quad 22$

4 Mean income by income group across villages (IDR/year). 22

5 Mean household income from forest in pilot 4 (IDR/year). 26

6 Mean households income. 26 


\section{Summary}

In Indonesia, natural resources are under pressure from both urban development and commercial exploitation. In Seram Island, Maluku, oil palm plantations are expanding in the north. In the south of the island, a State-owned cocoa company and a private logging enterprise are exploiting the vast territory of Waraka, an ancestral village established on the coast. The set of customary laws and principles of this village, locally called adat, is still powerful and is the basis of the traditional land tenure and land-use systems. In order to promote the socioeconomical development of his community, the king or raja of Waraka interacts with both companies within a dual and uncertain legal framework. The methodology in this study is based on the institutional framework analysis developed by Ostrom (1994) and a preliminary literature review. It also encompasses qualitative interviews. The evolution of the land tenure and land-use systems of Waraka is related to the strength of adat's recognition and the ability of the raja to conduct deals with both companies. The study finally discusses the possibilities for all stakeholders to manage the land in a more sustainable way through the implementation of a tree-nursery program funded by credit carbons or the use of reduced impact logging practices. 


\section{Acknowledgments}

First of all, I am very grateful to Yves Laumonier for organizing this extremely interesting and educational internship for me, and for his supervision in Indonesia. I would like also to thank Maya Leroy, my supervisor at Agroparistech.

I would also like to thank Tom Silaya (Pattimura University) and Professor Purwanto (LIPI), for sharing their experience with me and for helping me to get a better understanding of the situation before and during the fieldwork. I also want to thank Yan Persulessy (TOMA) for his help in conducting participatory mapping. Particular thanks goes to Merlyn Warere, who accompanied me during the first two weeks of fieldwork and who helped me to introduce myself to the community.

I want to give a warm thank you to Nining Liswanti and Emily Fripp who carried out the socioeconomic survey in Seram, for their patience and their kindness in discussing the methodology and the results of the study. Thanks also to Popi Astriani and Uceu Unangsih who helped me in all my administrative tasks, and to Danan Hadi for his significant support in cartography.

I am very grateful to Juliette Mouche from the French Forestry School, for her support, her useful proofreading and her valuable advice.

Last but not least, I am very grateful to the whole community of Waraka and in particular to: RYB Lailossa (Bapak Raja) and his wife Ibu Rining (Ibu Raja), for their warm welcome; Bapak Oceng's family, who hosted me for two months; Bu Yoksan, for helping me with my fieldwork; Ibu Nona's family for their friendship; and everyone from Waititai, and the surrounding neighborhood for sharing their knowledge. I had an amazing work and social experience thanks to all of these people. 


\section{List of abbreviations}

APL

BAL or UUPA

BAPPEDA

BAPPENAS

BFL

$\mathrm{BKPH}$

BKPRD

BKPRN

BUMN

CIFOR

CIRAD

CoLUPSIA

DPRD

FAO

HGU

HPH/IUPHHK-HA

IUPK

KAPET

HL

HP

HPT

HTI

IRD

KAPET

KBR

KKWT

LIPI

LC

LU

LUP

$\mathrm{MoF}$

$\mathrm{MoU}$

MPR

NGO

NTFPs

PES

PPN

PTPN XIV

REDD+

RePPProT

RDTR

RIL

RPJPD

RTRW
Areal Penggunaan Lain - other land-use

Undang Undang Pokok Agraria - Basic Agrarian Law (1960)

Badan Perencana Pembangunan Daerah - Provincial Development Planning Agencies

Badan Perencana Pembangunan Nasional - National Development Planning Agency

Basic Forestry Law

Badan Kemantapan Kawasan Hutan - Forest Mapping Agency

Badan Koordinasi Penataan Ruang Daerah - Coordinating Board for Regional Spatial Planning

Badan Koordinasi Penataan Ruang Nasional - Coordinating Board for National Spatial Use Management

Badan Usaha Milik Negara - State-owned company

Center for International Forestry Research

French Agricultural Research Centre for International Development

Collaborative land use planning and sustainable institutional arrangements for strengthening land tenure, forest and community rights in Indonesia

Dewan Perwakilan Rakyat Daerah - Provincial House of Representatives

Food and Agriculture Organization of the United Nations

Hak Guna Usaha - right of exploitation (concession)

Hak Pengusahaan Hutan / Izin Usaha Pemanfaatan Hasil Hutan Kayu - right of forest use (concession)

Ijin Usaha Penebangan Kayu - permit for wood exploitation

Strategic investment plan of Seram Island

Hutan Lindung - protected forest

Hutan Produksi - production forest

Hutan Produksi Terbatas - limited production forest

Hutan Tanaman Industri - industrial forest plantation

Research and Development Institute

Kawasan Pengembangan Ekonomi Terpadu - Integrated Economic Development Zone Kebun Bibit Rakyat - Community nursery program

Karyawan Kontrak antara Waktu - Temporary contract employee

Lembaga Ilmu Pengetahuan Indonesia - The Indonesian Institute of Sciences

land cover

land use

land-use planning

Ministry of Forestry

Memorandum of Understanding

Majelis Permusyawaratan Rakyat - People’s Consultative Assembly

nongovernmental organization

non-timber forest products

payment for ecosystem services

Perusahan Perkebunan Negara - public company of plantation

Perseoran Terbatas Perkebunan Nusantara XIV Persero (cocoa company's name)

Reduced Emissions from Deforestation and forest Degradation

Regional Physical Planning Project for Transmigration

Rencana Detail Tata Ruang - detailed spatial plan

reduced-impact logging

Rencana Pembangunan Jangka Panjang Daerah - Regional Long Term

Development Plan

Rencana Tata Ruang Wilayah - spatial plan 
RTRW-B/P

RTRW-K

RTRW-P/K

RTRW-P

STPDN

TBT

TGHK

THT

TN

TPTI
Regency spatial plans/provincial spatial plans

Rencana Tata Ruang Wilayah Kabupaten - District Spatial Planning

RencanaTata Ruang Wilayah Provinsi/Kabupaten - Provincial/District Spatial Planning RencanaTata Ruang Wilayah Provinsi - Provincial Spatial Plan

Sekolah Tinggi Ilmu Pemerintahaan Dalam Negeri

Tenaga Bulanan Tetap - monthly contract employee

Tata Guna Hutan Kespakatan - consensus-based forest land-use planning

Tenaga Harian Tetap - daily contract employee

Taman Nasional - National park

Tebang Pilih Tanam Indonesia - selective cutting and planting system 


\section{Introduction}

Environmental degradation and forest loss are increasing worldwide, with the most immediate impact occurring at the local level in tropical countries. The loss of ecological services provided by tropical forests, together with the reduced availability of renewable resource, is particularly important to populations who rely on natural resources for their livelihoods.

In Indonesia, even if the deforestation rates have decreased recently, the loss of forest is still high, with more than 500,000 hectares (ha) lost per year during the period 2000-2010 (FAO 2011). This high rate of deforestation is due to the need for development and the conversion of forest into agricultural land, logging, fire and mining (Sodhi et al. 2004). Indonesia is said to be one of the biggest emitters of carbon from land uses and land-use changes, and one of the top five greenhouse gas emitting countries in the world (Akiefnawati et al. 2010). In addition to environmental issues, tenure and natural resource exploitation policies have caused social and human rights problems (Colchester 2006; Yuliani 2010). Although many communities still rely on forest resources for their livelihoods, customary land rights are mostly ignored by the government (Safitri et al. 2011) while permits for large-scale concessions are regularly given to companies, leading to numerous conflicts between these companies and the local people (Winoto 2009).

Reconciling socioecological issues and the pressure of economic forces into appropriate policy and management strategies in such areas requires the facilitation of a participatory development approach for the empowerment of local stakeholders in landuse and resource management planning, a deeper analysis of socioecological systems at the landscape level, and a strong commitment to tackling landtenure issues.

Policy interventions in land tenure can generate both positive and negative results, but a policy based on accurate and open information, participation of all stakeholders and an appreciation of changing, dynamic contexts, is more likely to lead to the intended results. Without a proper understanding of land-tenure issues, any attempt to promote propoor financing mechanisms (payment for ecosystem services, PES; Reduced Emissions from Deforestation and forest Degradation, REDD; microcredits) may be jeopardized or may even fail.

In this context, the Collaborative Land Use Planning and Sustainable Institutional Arrangement project (CoLUPSIA) was designed to: establish more collaborative and equitable land-use planning (LUP) at regency level in Indonesia; and research and test new institutional arrangements, environmental policies and pro-poor financing instruments based on more secure land-tenure and community rights.

Building on existing materials and participatory techniques, collaborative surveys have been undertaken with several communities, focusing on the demographic, socioeconomic and cultural aspects of resource management by communities living in the area. Critical issues for the survey are to understand traditional resource management systems and their interaction with the government system, community perceptions of trends and priority issues in resource management.

Mapping of land use (LU) and land cover (LC) is essential data for land tenure and preparation of potential REDD/PES implementation. The resulting maps including land attributes and maps based on community perceptions guide the decision process on future desirable land uses, taking into account local people's requests. Environmental maps and classification of land cover/vegetation, a socioecological database, and a refinement of land allocation zoning are the primary deliverables for use in a subsequent negotiation process. Carbon pool (mainly biomass and soil) measurements and water-forest relationships have been studied to asses the potential of using payments or rewards for ecoystem service initiatives, in parallel with the more traditional support of developing high-value crops (cloves, nutmeg) and new commodities that will generate greater economic development from the limited land and resources available (Liswanti et al. 2013).

Following CoLUPSIA's livelihood survey analysis, the regency was stratified into 'pilot areas' representing groups of villages with common socioecological characteristics. The socioeconomic conditions and future challenges of these pilot areas have been described by Liswanti et al. (2013), who concluded 


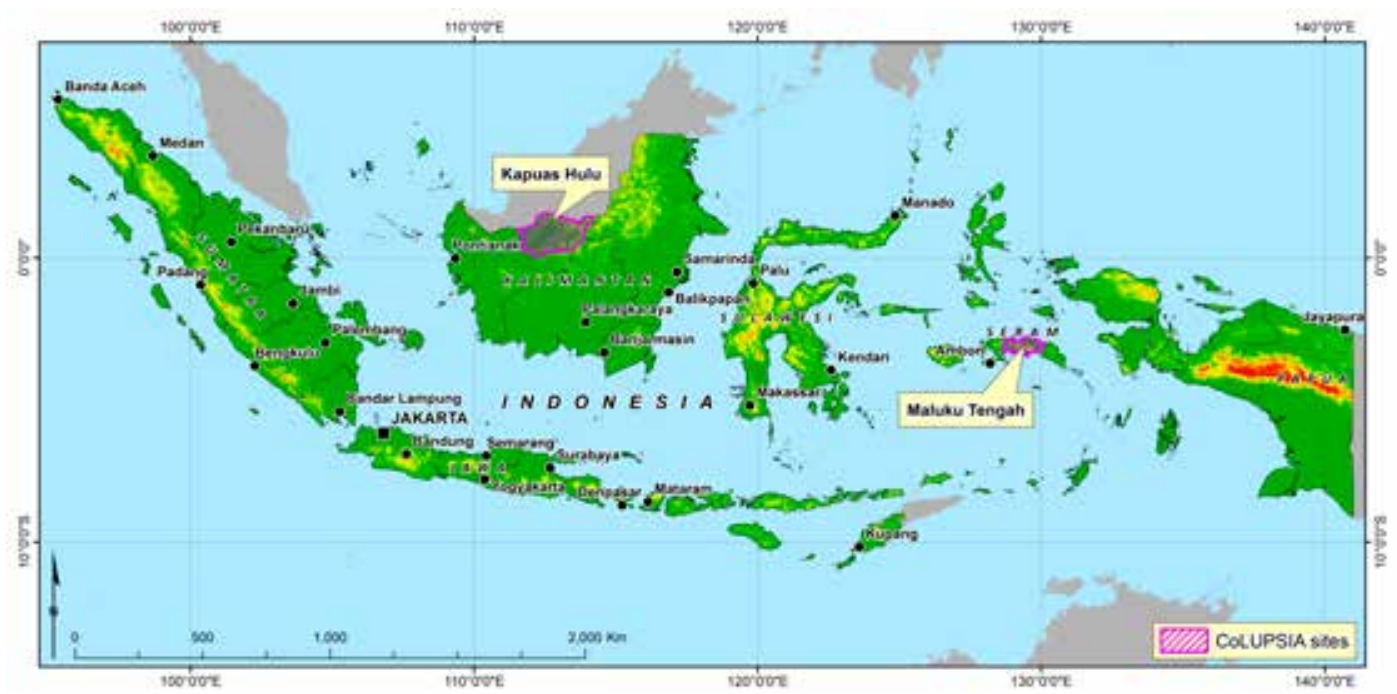

Figure 1. Indonesia and CoLUPSIA sites in Kalimantan and Maluku.

Source: CoLUPSIA project

that for all of them, the issues of: land use, access to land and forest resources, ownership and boundaries, the need for economic development and population growth, are collectively putting pressure on the limited resources of Seram, resulting in conflict between users in many cases.

'Pilot site 4' represents "villages that are more integrated or have access to urban areas due to their closer proximity to the regency capital" (Liswanti et al. 2013). My study focused on Waraka, one of the villages of this area. The primary reason for this choice is that this village has a strong system of customary laws or adat, for management of the land, and influence and recognition by other villages. Another reason is that the village is currently at a critical juncture regarding the development of companies on its territory. One company started logging operations a few months ago and the second wants to obtain the renewal of its 30-year concession that ended last year. Both companies are negotiating with the communities to find compromises. The previous socioeconomic survey identified the existence of these two companies but did not give any information about the relationships that they had with the community of Waraka nor about their impact on the environment and local society.

Urban development, population growth and the expansion of commercial activities may increase pressure on environmental resources and on traditional ways of managing these resources. Is this pressure on land-use change creating negative impacts, such as water quality deterioration, reduction in agriculture yields and limitations in community activities, or is it beneficial for communities, depending on the area converted, the compensation received and the potential for employment? What are the features and conditions of contracts signed by Waraka inhabitants with the cocoa and logging companies? And which socioeconomic or environmental impacts these contracts may have?

In order to identify the possible impacts of these pressures on natural resources, we need to understand the evolution of land use. We need to examine whether traditional agroforestry systems are still widely used in Waraka, by whom, and if they can be considered as a viable option in keeping a better balance between the preservation of environmental services (biodiversity, water, soil conservation) and the socioeconomic development of Waraka.

After an explanation of the methodology used, the results of the spatial planning and governance, land-tenure and land-use systems analysis will be presented. The last section will briefly focus on the stakeholder network of the situation, before introducing a discussion on the results presented.

This research study has three objectives:

- to identify and localize the different customary land uses and land tenure system

- to analyze the impact of enterprises expansion on local society and on the environment

- to assess the robustness of traditional land-use and land-tenure systems of Waraka community in a rapidly changing environment. 


\section{Materials and methods}

\subsection{Field site}

The study area is located on the land of the Waraka Village, on Seram Island in the Moluccas (Maluku). The island covers an area of $17,429 \mathrm{~km}^{2}$ (Monk et al. 1997), with 189,000 ha covered by Manusela National Park. The island is mountainous, not volcanic, with the Binaya peak just over $3000 \mathrm{~m}$, and is mainly composed of sedimentary and metamorphic rocks (Edwards et al. 1993). Seram Island is part of the Wallacea region; its flora and fauna is a mix of Asian, Australian and New Guinean elements, and its climate is tropical everwet, with precipitation which varies from $2000 \mathrm{~mm}$ to over $3000 \mathrm{~mm}$ annually. The total population of Central Maluku - composed of the central part of Seram Island, the Banda and the Lease Islands - has 434,490 people, with approximately 175,500 people in Seram and 11,434 people in the subdistrict of Teluk Elpaputih, where Waraka is located (Badan Pusat Statistik 2010). The surface of the subdistrict is about $120 \mathrm{~km}^{2}$ (Badan Pusat Statistik 2010), with a density of 95 inhabitants $/ \mathrm{km}^{2}$. The population is relatively young and expected to grow in forthcoming years. The majority (93\%) of the population is of productive or working age (Liswanti et al. 2013). Issues on land use such as access to land and forest resources, ownership and boundaries, the need for economic development (and access to markets), and population growth are collectively putting pressure on the limited resources of Seram, and in some cases resulting in conflict between users (Liswanti et al. 2013).

Waraka is a traditional village with six main clans and four new clans, with clear boundaries and ownership recognised within the adat (traditional law). It was established in 1889 and has a population of 1721 inhabitants, who are Christian and Muslim. As a traditional village there is an administration system with a king or raja and a saniri negeri, the village assembly where all clans are represented. Waraka is relatively urban when compared with other areas as the community is close to Masohi, the capital of the regency.

\subsection{Theoretical framework}

A conceptual framework approach can be used to facilitate the study of the factors that influence land-tenure security and land-use rights transfer to companies. The institutional analysis and development framework developed by Ostrom et al. (1994) was applied to the issue of land-tenure and land-use rights in this study. This conceptual framework has a basic structure constituted by "an

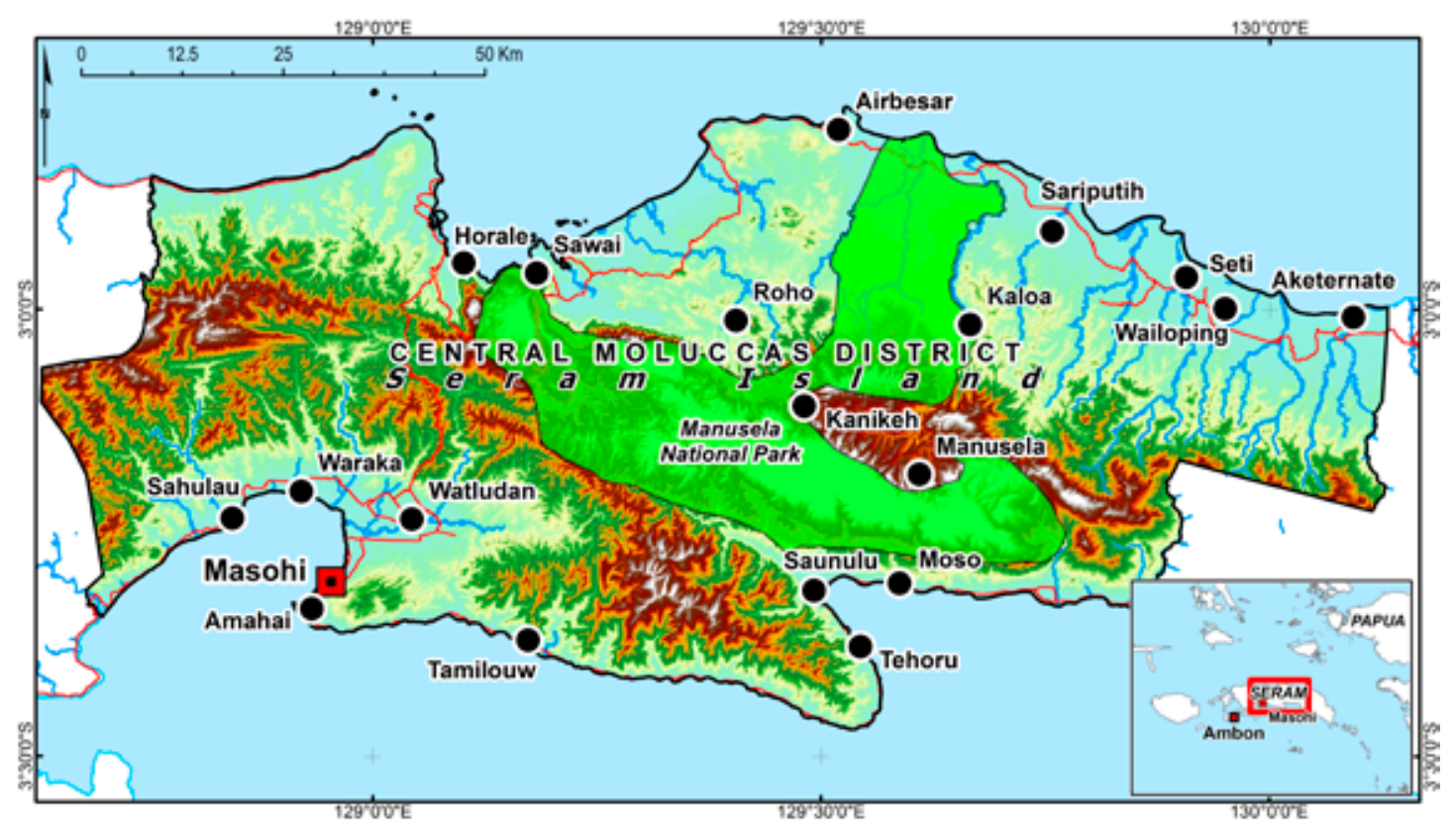

Figure 2. Seram Island, Moluccas.

Source: CoLUPSIA project 

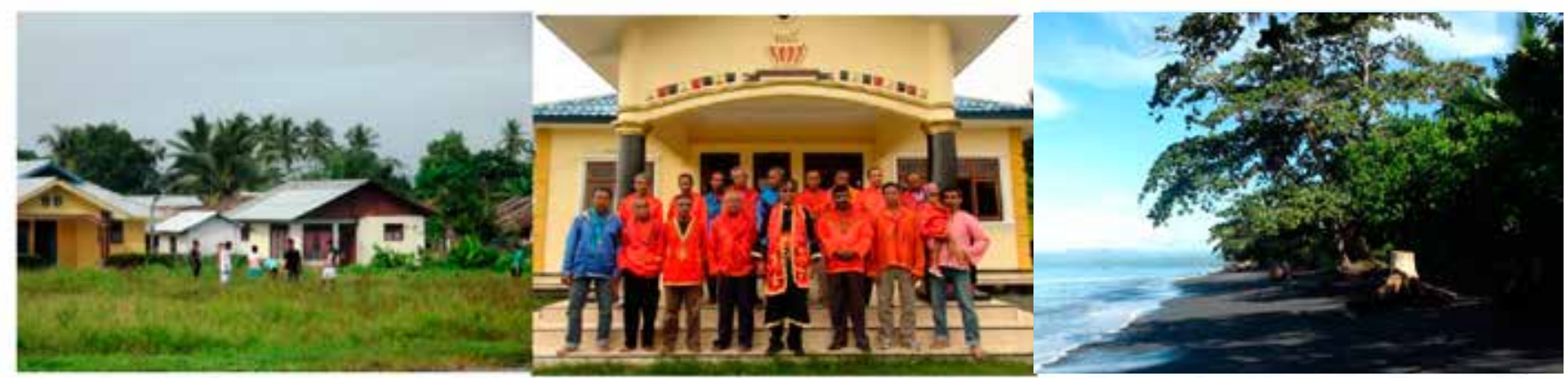

Figure 3. From left to right: Houses of Waraka, the raja with the saniri negeri and a view of the coast.

\section{ENVIRONMENT}

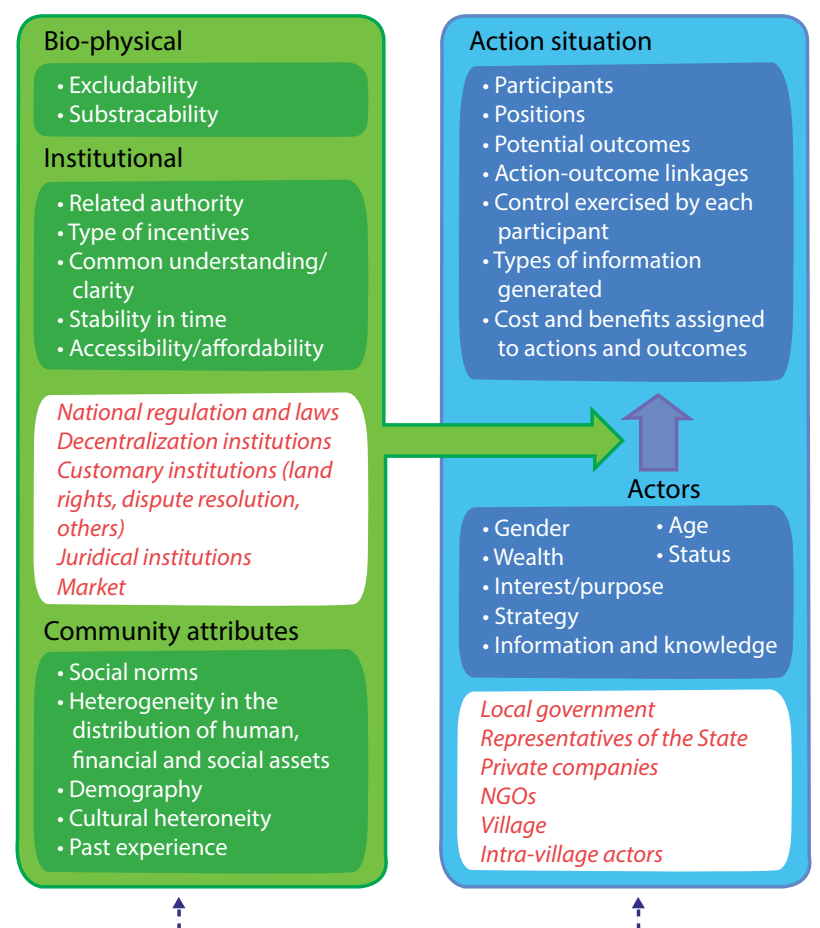

\section{PATTERNS OF INTERACTIONS}
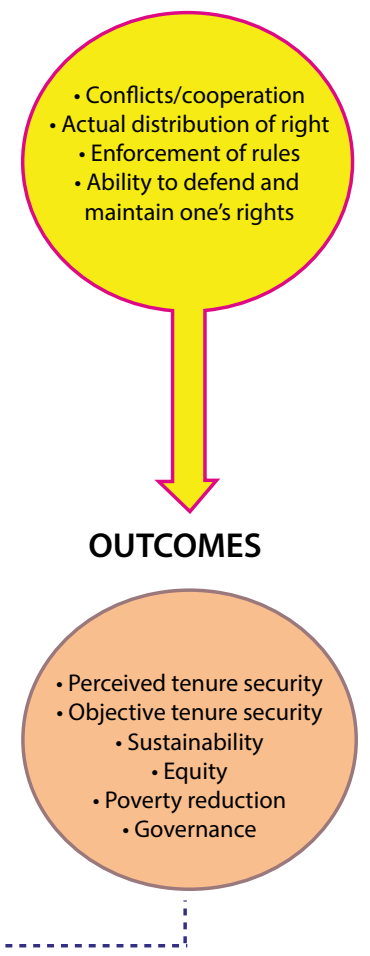

Figure 4. Institutional analysis and development framework applied to land-tenure security.

Source: Clerc (2012)

exogenous set of variables that influence situations of actors and the behavior of actors in those situations, leading to outcomes, which then feed back to modify both the exogenous variables and the actors and their situations" (Dorward and Omamo 2009). These exogenous variables constitute the 'environment' which influence the action situation and the behavior of the actors, positioned in the 'action arena' or 'action domain' (core research unit corresponding to "social spaces in which actors interact in social and economic exchange", in this case).

The framework focuses on the research unit - a land-tenure system at the village level, which corresponds to the action arena (see Figure 4).
Members of the community interact with one another to manage their natural resources. They are influenced by their environment (land use, infrastructure, geography) and by the political and institutional context. Many actors play a role in land-tenure issues: national and regional governments, private and public companies, nongovernmental organizations (NGOs) and village-level groups. They are characterized by their action resources that include:

- Information: How actors acquire information, the kind of information they want and how they use it. Information increases the control that an actor can exercise 
and their bargaining power when negotiating with other actors.

- Social status: It influences the control that can be exercised in the action arena and the accessibility of authority and decisionmaking entities.

- Interests and the strategy adopted to reach them.

All actors have direct and indirect interests in the land around the village. These actors are ruled by institutions which decide on the attribution of use and management rights of the forest land and that can represent a constraint or an opportunity in terms of the goal of each actor. They also have a certain position in the action arena, according to their power and their ability to control rules or claim and defend their rights. They have a dynamic relationship with the institutions. Institutions can be defined as the formal and informal rules that govern people's behaviour by providing a framework of incentives (Clerc 2012).

This conceptual framework and institutional analysis developed by Ostrom takes into account the dynamic aspect of land tenure security (Clerc 2012). It will be used to facilitate the study of the factors that affect land-tenure security in the fastchanging context of companies' establishment in Waraka's territory.

\subsection{Literature review}

Two months were spent reviewing the literature (journal articles, books, websites, internal reports, among other documents). The aims of this review were:

- to get a better understanding of the national and regional systems of land use and land tenure in Indonesia and Maluku

- to generate elements for comparison between the situation in Waraka and other territories (formal structure, customary laws, etc.)

- to provide a basis for a discussion about the possible implementation of development projects or payment for ecosystemic services program.

The literature on Waraka is poor, but there a socioeconomic survey performed by the CoLUPSIA team interviewing 30 households (Liswanti et al. 2013). It gives a background understanding of the situation in Waraka (level of education, mean annual incomes, main production of cash crops, etc.).

\subsection{Field data collection}

As there is almost no literature about Waraka, it was important to go to Waraka to get a better understanding of the situation. I spent 2 months with the community, a period long enough to establish relations of trust with villagers and members of the companies. I organized focus-group discussions with participatory mappings and semi-structured interviews to identify the traditional land-use and land-tenure systems of the village. Visits to the field enabled me to triangulate the information, meet people that I would not have met in the village and localize the different land-use areas with a GPS.

I could speak Bahasa Indonesia before I went to the field site, so I did not need a translator. I received a useful induction program from Merelyn Marere, a young woman from Ambon (the capital city of Maluku) who had recently graduated in environmental management. from Pattimura University. She had previous experience of working in other villages of Seram, where she interviewed farmers with Nining Liswanti (CoLUPSIA). She helped me to adapt and settle in, especially with the family I was staying with, and to understand the local language that has a few vocabulary differences from the national language.

\subsubsection{Focus group discussions}

At the simplest level, a focus group is an informal discussion among a group of selected individuals about a particular topic (Wilkinson 2004). Here, our objective is to describe and understand interpretations of a selected group of people. It enables us to gain a better understanding of a specific issue from the perspective of the participants in the group.

In total, six sessions were organized during the first two weeks. They concerned, separately, women older or younger than 35 years old (two sessions), men older or younger than 35 years old (two sessions), and a mixed gender and age group (two sessions). The first four meetings were conducted as 'multipleinformants interviews', with a guideline from a previously prepared questionnaire (Appendix 1). It gave an idea of the situation, with some quantitative data on areas of mixed forest gardens and qualitative data about the evolution of farmers' production or their past and actual experiences with the companies 
operating in the region. Later, I organized two collective discussions with largely open questions, no guidelines and no questionnaires. The idea was to let the participants talk about any topic related to forest and land use. People from both religions (Christian and Muslim) attended the first meeting of the presentation, but when the meeting took place in the Muslim part of the village, all who attended were Muslim and when it took place in the Christian part, all attendees were Protestant. Even if they have houses in distinct areas, today Muslim and Christian people seem to live in harmony in Waraka. According to villagers, the physical distinction in the two neighborhoods became stronger after the religious conflict that occured between 1999 and 2002 in Ambon and some parts of Seram that lead to the reallocation of thousands of people. The term 'Christian' refers to both Protestant and Catholic people. In Waraka, $78 \%$ of people are Protestants, $18 \%$ are Muslims and $4 \%$ are Catholics (data recorded by the assembly of the village for a population of 1317 inhabitants). There might be other reasons (historical or cultural, for instance) for such a categorization of the population. I chose not to look further into the study of this categorization due to time constraints. This abstraction may introduce a bias in the understanding of traditional land-use and land-tenure systems. Future research could explore this particular point.

\subsubsection{Participatory mapping}

These focus-group discussions were used to ask participants to draw a sketch of land use around Waraka. The idea was to conduct a preliminary participatory mapping exercise. However, it soon became obvious that the zone of farming around Waraka was a mosaic of multiple cropping and that it was very difficult for the participants to visualize and draw the land use in the region. Later Yan Persulessy from an environmental Ambon-based NGO,

TOMA, working with the CoLUPSIA project, carried out a mapping exercise with the help of three villagers chosen for their knowledge of adat territory's delimitation (two members of the village assembly and the customary forest guard). The objective was to draw a map of the traditional territory of Waraka (adat territory, Figure 11). It was reviewed and approved by the raja.

\subsubsection{Semi-structured interviews}

The objective of the semi-structured interviews was to examine the informants' viewpoint about their situation and their systems of analysis, classification and definitions. We were careful not to give a preestablished typology or abstract categories of the different land uses. All interviews were conducted in Bahasa Indonesia. Before starting any formal interview, I always introduced myself as a French student of forestry, working at CIFOR, based in Bogor and I presented the aim of my study through the CoLUPSIA project.

About 20 key informants were chosen according to their specific knowledge: a scientist from Pattimura University, Waraka inhabitants (adat's representatives, members of the village assembly, foresters or forest guards), directors and employees of the public and private companies, member of Rainforest Alliance (certification of nutmeg). Foresters, representatives of the commercial companies and the raja of Waraka have been interviewed many times. During the fieldwork period the situation evolved quickly and data needed to be updated regularly. I met about 10 different farmers to get quantitative data and
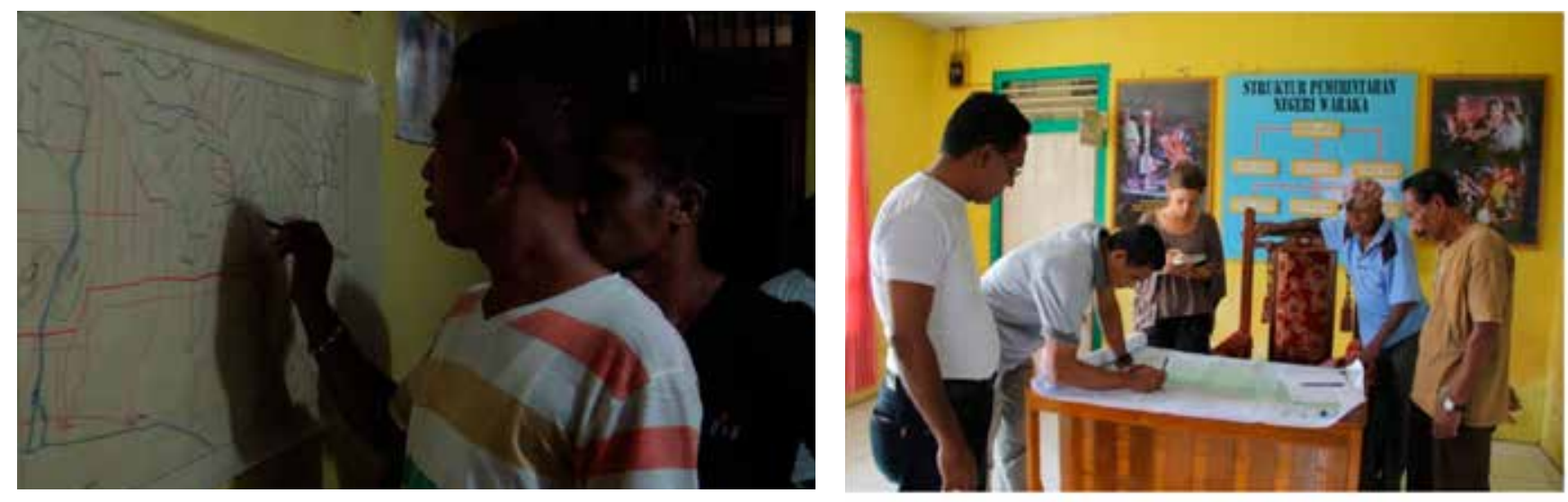

Figure 5. Participatory mapping during a focus-group discussion with men under 35 years old (left) and with Yan (CoLUPSIA partner), members of the saniri negeri and the raja at Waraka, June 2013 (right, photo by Y. Purwanto). 
ask more details about the evolution of their past and actual production. They had been selected randomly based on the map of the different households of the village (See Appendix 2 for a full list of the people interviewed). More than half of the interviews happened during the first 2 weeks of the fieldwork, and the others were conducted during the period of my stay in Waraka. I lived in the village for two and a half months and I also got a wealth of information through daily informal discussions during that time.

\subsubsection{Fieldwork}

In order to improve the land-use cover map previously established by CoLUPSIA ${ }^{1}$, to explore further the importance of traditional land uses and to meet people that I would have not have met in the village because of their remoteness, I went into the field 24 times. I made three pre-arranged visits to the offices and commercial plantations of the public company that produces cocoa, coconut and rubber. I made two visits to the logging sites located in the mountains $15 \mathrm{~km}$ from Waraka and I made 19 visits to food crop fields and mixed tree gardens of the local community. I checked the borders (presence of bollards, for instance) between the company and local farmers' lands and I examined the condition of the crops (pest and disease, age, etc.). For the official visits to the companies, the raja of Waraka phoned the directors before I went so that there was always somebody to receive me and answer my questions. After I was introduced to the cocoa company staff, I also went to visit their rubber plantations without warning them in advance - the staff there were always available and glad to talk to me. For the trips to local famers' plantations, I scheduled the visit with the owners in Waraka, or I went on my own with one of the customary forest guards (Yoksan Matitamole) and met the villagers directly in the field. I chose my destinations according to what the local people had told me during the focus-group discussions and the subsequent mapping exercise ("we have clove plantations there", "food crop fields are located in this other part", etc.), or according to the CoLUPSIA land-cover map (to check if a specific plantation was as shown on the map), or simply if an opportunity arose (e.g. some farmers invited me

1 A land-cover map had been previously established by CoLUPSIA based on the analysis of 2013 LANDSAT satellite imagery. to visit their garden when they wanted to produce sopi, an alcohol made from a sugar palm).

\subsection{Data analysis}

The data analysis started during the field period in order to adjust the methodology. Basically, it consisted of highlighting key data and structuring some information to get a better understanding of the situation.

Based on notes and interviews transcripts, part of the analysis was dedicated to understanding the actors' network in the struggle for power. Discussions with other members of the CoLUPSIA program helped me to complete this task by bringing new elements of reflection and comparison. A third element of the data analysis concerned the assessment of the impact that both commercial companies may have had on the local society. It was based on both qualitative and quantitative information collected through the various interviews. Basic calculations were made to estimate potential changes in terms of employment need in rubber plantations. However, an environmental impact assessment was not done, so the analysis of the potential impact that the companies may have had on the forest and on the biodiversity is so far of a more speculative nature.

After the fieldwork, part of the analysis consisted of establishing a map and a description of land use. It was made based on the previous CoLUPSIA land-use map, with modifications according to the local community's classification and personnal observations. For places I was not able to visit due to time restrictions, modifications were based on farmers' interviews and an analysis of new 2013 satellite imagery. When possible, GPS (Garmin type etrex vista $\mathrm{HCX}$ ) was also used to precise borders and locations. Danan Hadi (CoLUPSIA) scanned and processed the second map of adat and administrative Waraka territories with GIS. Then I met the raja who was in Jakarta at that time and improved it again. Finally, all the data collected and produced during this study have been transmitted to the CoLUPSIA project and to CoLUPSIA partners who work in Maluku (Tom Silaya, Pattimura University, and Yan Persulessy, Toma). Due to its high costs, this report will not be translated into the national or local language. 


\section{Results}

\subsection{Land tenure system and rights in Indonesia}

Fuys et al. (2008) defines tenure security as a function of rights, which depends on their breadth and duration. Clerc (2012) say that land tenure security is assured if a rights holder can, now and in the future, profit from the investment that he made on his land (labour and capital). There are two schools of thought about land rights. In his book The Tragedy of the Commons (1968), Hardin demonstrated that without private or state control, an open-access area will inevitably lead to resource degradation. This forms the basis of the property rights school, which holds that private, individual and tradable property rights form the most efficient tenure system. In contrast, the common property school emerged in the 1980s, with a focus on traditional resource management and the benefits of collective action. Property rights are maintained but they are exerciced collectively (Thompson and Wilson 1994). This theory encompasses the idea that one land has various resources that can be managed by several individuals. The notions of land tenure and land-rights security should then be adapted to the related context of study.

In Indonesia, there are two fundamental laws which adress the issue of land tenure and rights and reaffirm the 1945 Constitution of Indonesia: the Basic Agrarian Law No. 5 of 1960 (BAL), which covers a wide range of issues on land ownership and land-use related to private and state-controlled land; and the Basic Forestry Law of 1967, revised in 1999.

\section{The Basic Agrarian Law}

The Basic Agrarian Law (BAL) of 1960 is considered to be the most important law governing land rights (USAID 2010). Although it states that: "the earth, water and air space, including the natural resources contained therein, are in the highest instance controlled by the State as an Authoritative Organization of the whole people", it confirms the recognition of customary rights (Articles 3 and 5). The BAL is viewed as a strong legal basis for customary land rights protection (Harwell 2000; Sirait 2009). However, these rights are recognised and delegated to provincial government and the local adat community as long as: "there is no conflict with national interest and provisions of the State Act" (Article 2, Section 4). Thus, recognition of customary land rights faces strong restrictions. The official explanation of Article 5 of the BAL clarifies these limits of recognition: "Nevertheless, it is not acceptable for customary law communities to invoke customary (ulayat) rights to oppose business utilization rights [...] or development projects, for example opposing forest clearing for generating local income or resettlement programs" (Clerc 2010).

After the fall of President Suharto in 1998, a decentralization process started. Districts and cities assumed new responsibilities, such as land affairs, that were previously covered by the national government (Law No. 22). In 2004, Law 32 defined regional autonomy as "the right, authority and obligation of an autonomous region to govern and manage State affairs and interest of the local people on its own in accordance with the existing law" (Article I, paragraph 5 of Basic Agrarian Law 32-2004).

\section{Main form of rights}

The BAL defines the fundamental types of rights that may be held by private individuals and entities (Mitchell et al. 2004). The main forms of tenure include:

- Hak milik (right of ownership) represents hereditary rights, unlimited in time and capable of being transferred and mortgaged. It is the strongest right on land that can be allocated to a person.

- Hak pakai (use right), applies to possessory rights, such as usufruct, and does not have a permanent quality.

- Hak guna usaha (HGU; right to exploit), is the right to cultivate the land directly controlled by the state, within the period mentioned in Article 29 (Section 29), for agriculture, fisheries or livestock.

- Hak guna bangunan (right to build), applies to rights to construct and use buildings.

- Hak sewa is the right of a person or company to use the land for building purposes and in exchange for a sum of money to landowners.

\section{The Basic Forestry Law}

In 1967, the Basic Forestry Law (BFL, Law No. 5 of 1960) placed all forested land (130.7 million ha 
or approximately $68 \%$ of the country) under the planning and regulation of the state through the Directorate General of Forestry. After 1967, the BAL was not applied to forestland, and the Ministry of Foresty assumed greater significance. During the New Order period (1965-1998) the state favored large-scale private investment and organized huge transmigration programs, mainly ignoring customary rights. In 1999, the Forestry Law (Law No. 41 of 1999) replaced the BFL. A new era of decentralization of powers from the central government to the regency (kabupaten) started, but it was sometimes marked by lack of planning (USAID 2010).

\section{Other laws}

Other important laws include: Law on Conservation of Biodiversity and Ecosystems (Law No. 5 of 1990), Law on Spatial Use Management (Law 24 of 1992) and Law on Management of the Environment (Law No. 23 of 1997). In 2001, the decree TAP IX on Agrarian Reform and Natural Resources Management issued by the People's Consultative Assembly (Majelis Permusyawaratan Rakyat or MPR) brought new hope for the recognition of customary land rights. Indeed, the decree instructed the president and the Indonesian House of Representatives (DPR; Dewan Perwakilan Rakyat) to engage in a process of harmonization on laws concerning land use and natural resources issues (USAID 2010). However, the decree has not yet been developed into regulations on customary landrights recognition.

The national legal framework remains unclear. The national constitution recognizes customary or adat laws and its Article 45 (Makam Konstitusi or MK 45) gave the communities new hope of getting more rights over their lands, while the state clearly favors large private investments. This ambiguity has led to several conflicts throughout the country. It is a constant difficulty, which reduces the efficiency of the land-use planning process and implementation in Indonesia.

\subsection{Land-use planning in Indonesia}

Alexander (1992) defines land-use planning as: "the development of regulatory, developmental and conservation strategies for land, taking into account the interactions between land; or, more broadly, the built and physical, social and cultural characteristics, and their institutions, norms and values".

Land-use planning in Indonesia started in 1967 with an initiative of the Ministry of Forestry $(\mathrm{MoF})$. Since then it has evolved and different laws have been implemented to support this process of territory management.

\subsubsection{First initiatives in Indonesia (1967-1992)}

The first stage of national land-use planning was conducted by the Ministry of Forestry in 1982, with consensus-based forest land-use planning (Tata Guna Hutan Kespakatan or TGHK). Provincial maps at a scale of 1:500,000 were legalized and 144 million ha of Indonesia's territory were classified into Forest State land (Kawasan Hutan). To support transmigration programs, the Regional Physical Planning Project for Transmigration (RePPProT) proposed new TGHK maps at a scale of 1:250,000 with new land-use zones which included areas for reforestation (RePPProT 1990). These maps became the only reference for land-use planning issues. They have been used to facilitate private investments and various problems such as conflicts between concessionaires and local communities (Santoso 2003).

\section{RTRW-P/K}

In order to improve spatial land-use planning at provincial level, a new process called RTRW (Rencana Tata Ruang Wilayah) was established in 1992.

Coordinated by the Coordinating Board for National Spatial Use Management (BKPRN) and the National Development Planning Board (Badan Perencana Pembangunan Nasional; BAPPENAS), they initiated a partial decentralization process (Wollenberg et al. 2009). Provincial spatial plans or RTRW-P were made by newly -founded provincial development planning agencies (Badan Perencana Pembangunan Daerah; BAPPEDA, coordinated by the BAPPENAS). Regency spatial plans or RTRW-K were also planned. RTRW-P/K plans aimed to provide more detailed documentation about administrative limits, characteristics about land, potential natural resources and multisector opportunities for development.

\section{Process of decentralization}

After the fall of Suharto's regime, decentralization laws empowered the regencies' governments. In 1999, districts and cities assumed new responsibilities, such as land affairs, that were previously covered by the national government (Law No. 22/1999). A growing 


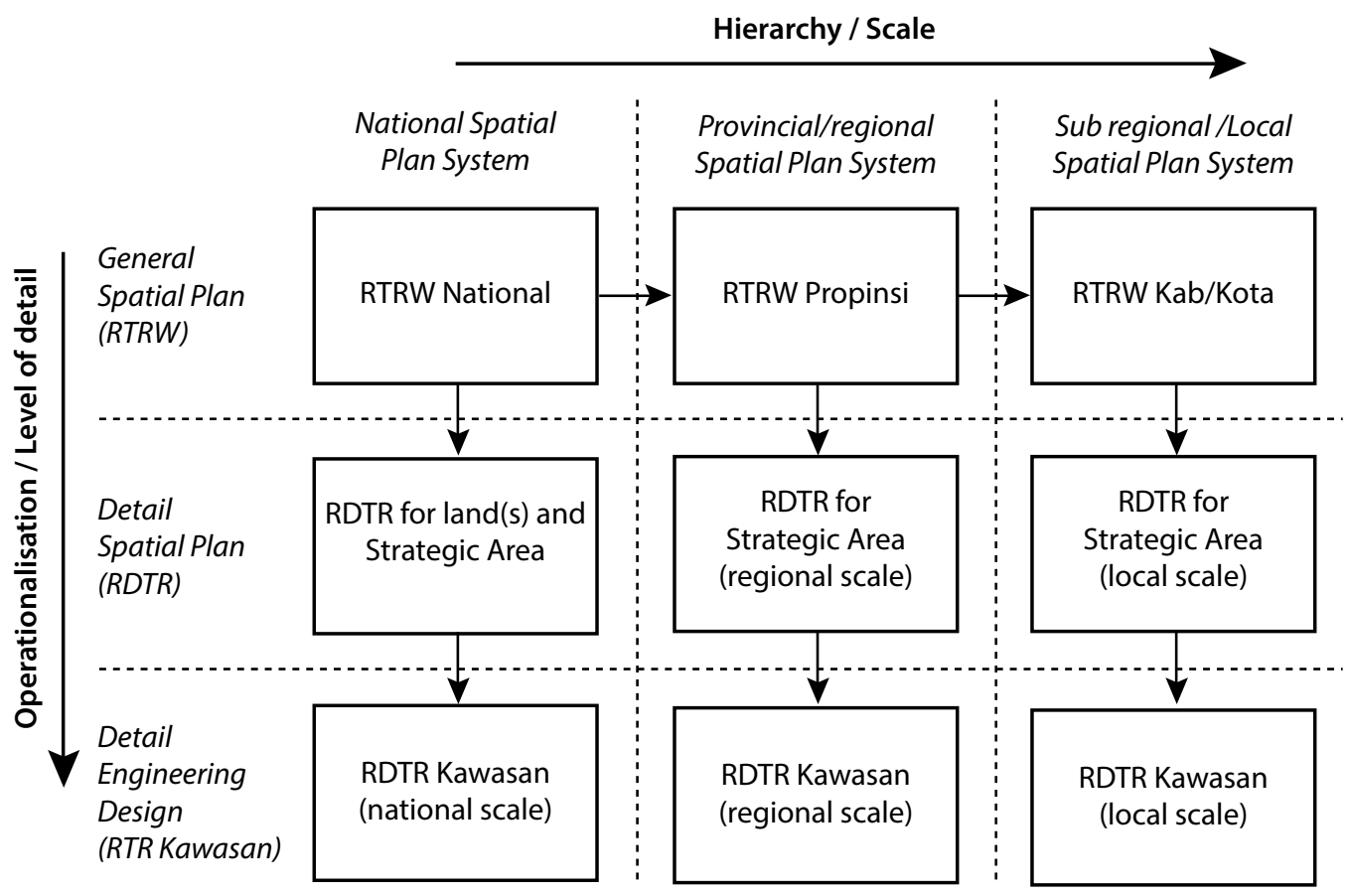

Figure 6. Spatial planning system in Indonesia.

Source: Priatna et al. (2010)

number of the regencies engaged in spatial planning processes and synchronized maps replacing the old TGHK maps. However, many spatial plans were rarely checked in the field. Further, following decentralization reforms, uncontrolled natural resources exploitation, such as illegal logging, became widespread across Indonesia. The government reacted by passing new national laws and regulations in 2004. Law No. 32/2004 in particular required the regency land-use plans (RTRW-B) to be coordinated with the provincial and national plans.

Finally, a new law on spatial planning UU 26/2007 brought a new framework for institutional settings, decentralized governance and new trends on land use and management in Indonesia.

\subsubsection{The situation in the Moluccas}

\section{Spatial plans}

The Central Moluccas Regency Spatial Plan (RTRW - K) was drafted in 2008. The draft of regional law was examined by the province BKPRD and it was finally sanctioned by the governor in 2009. Today a revised version (2011) is still waiting for the approval by the Ministry of Forestry and legislative assembly (Dewan Perwakilan Rakyat Daerah; DPRD). The Moluccas province spatial plan's formulation started in 2005 but it has not yet been approved.

\section{Institutions involved}

Durey (2014) established a list of the main institutions involved in the spatial planning policies in Maluku and their link to national level.

In the Moluccas (and in other provinces), there is a lack of communication between institutions dealing with spatial planning (Durey 2014). Vertical communication between governance levels is hindered by a lack of infrastructure for communication and transport. Hence, sometimes decisions made at regency level are not in line with provincial-level decisions (Djogo and Syaf 2003).

\section{Regional conflict}

After the religious conflict of 1999-2004, Moluccas' regional agencies had difficulties in rebuilding and a lot of data has not yet been updated. Forest delineation maps used by the forestry agency date from 1999, for instance. Thematic maps for forestry are done by the forest mapping agency or BKPH (Badan Pemantapan Kawasan Hutan) using a 1:250,000 scale for the regency and provincial spatial plans.

\section{Lack of connection between land-use planning instruments}

There are three main instruments for land-use planning in Seram Island. First, the strategic investment plan of Seram Island or KAPET aims 
Table 1. Main institutions involved in land-use planning policies in Maluku.

\begin{tabular}{|c|c|c|c|c|c|c|c|c|}
\hline Mechanism & $\begin{array}{l}\text { Land-use } \\
\text { permits } \\
\text { allocation }\end{array}$ & $\begin{array}{l}\text { Forest estate } \\
\text { spatial planning, } \\
\text { delineation } \\
\text { (TGHK), control } \\
\text { and monitoring }\end{array}$ & $\begin{array}{l}\text { General spatial } \\
\text { planning } \\
\text { mechanism for } \\
\text { all land RTRW }\end{array}$ & $\begin{array}{l}\text { Detailed spatial } \\
\text { planning and } \\
\text { strategic spatial } \\
\text { planning (RDTR, } \\
\text { RTR Kawasan } \\
\text { Strategis) }\end{array}$ & $\begin{array}{l}\text { Seram economic } \\
\text { zone planning } \\
\text { KAPET }\end{array}$ & $\begin{array}{l}\text { Long- and } \\
\text { medium- term } \\
\text { development } \\
\text { programs } \\
\text { (RPJP/RPJM) }\end{array}$ & $\begin{array}{l}\text { Land tenure } \\
\text { affairs: conflics } \\
\text { resolution, } \\
\text { ownership } \\
\text { certification }\end{array}$ & $\begin{array}{l}\text { Conservation } \\
\text { areas } \\
\text { management: } \\
\text { national park } \\
\text { and other } \\
\text { conservation } \\
\text { areas }\end{array}$ \\
\hline $\begin{array}{l}\text { Central state } \\
\text { level }\end{array}$ & - & $\begin{array}{l}\text { Ministry of } \\
\text { Forestry }\end{array}$ & $\begin{array}{l}\text { BAPPENAS } \\
\text { (development } \\
\text { planning } \\
\text { agency) / PU } \\
\text { Public work } \\
\text { ministry }\end{array}$ & - & $\begin{array}{l}\text { KAPET } \\
\text { Development } \\
\text { Agency (Badan } \\
\text { Pengembangan } \\
\text { KAPET Bapeng) }\end{array}$ & BAPPENAS & $\begin{array}{l}\text { BPN land affairs } \\
\text { ministry }\end{array}$ & $\begin{array}{l}\text { Ministry of } \\
\text { Forestry: general } \\
\text { directorate of } \\
\text { forest protection } \\
\text { and nature } \\
\text { protection } \\
\text { (PHKA) }\end{array}$ \\
\hline Province level & $\begin{array}{l}\text { Governor } \\
\text { (for land } \\
\text { acreage } \\
\text { above a } \\
\text { certain } \\
\text { limit) }\end{array}$ & Forestry agency & $\begin{array}{l}\text { BAPPEDA/Public } \\
\text { work agency }\end{array}$ & $\begin{array}{l}\text { BAPPEDA/Public } \\
\text { work agency }\end{array}$ & $\begin{array}{l}\text { KAPET Seram } \\
\text { agency }\end{array}$ & BAPPEDA & $\begin{array}{l}\text { BPN land affairs } \\
\text { agency }\end{array}$ & $\begin{array}{l}\text { Deconcentrated } \\
\text { subsidiaries } \\
\text { from PHKA (do } \\
\text { not follow the } \\
\text { administrative } \\
\text { divisions) }\end{array}$ \\
\hline Regency level & $\begin{array}{l}\text { Regency } \\
\text { head }\end{array}$ & Forestry agency & $\begin{array}{l}\text { BAPPEDA/Public } \\
\text { work agency }\end{array}$ & $\begin{array}{l}\text { BAPPEDA/Public } \\
\text { work agency }\end{array}$ & - & BAPPEDA & $\begin{array}{l}\text { BPN land affairs } \\
\text { agency }\end{array}$ & - \\
\hline
\end{tabular}

Source: Durey (2014)

to determine development areas in Seram following their potentials to facilitate investment. Second, there is the regional medium-term development program (RPJPD), which aims to match development policies with land-use planning. These two instruments must be harmonized together with the BAPPEDA land-use planning (RTRW-K) in order to improve territorial policy implementation (Durey 2014). However, the coordination is not optimal and data are not shared. For instance, production forest superficies between KAPET and RTRW information often do not match.

\subsection{Land-use planning and tenure in Waraka: Two territories with two structures of governance}

\subsubsection{Definitions}

Adat is the name given in Bahasa Indonesian to the set of customary institutions and laws used by local communities. The organization and social rules and activities related to land-use and land-tenure systems of families and villages are based on the adat. This range of guiding principles can be developed in different ways according to the communities and is passed down orally from generation to generation.

Negeri refers to a village in terms of territory and governance. It can be a negeri adat, with the attributes of a traditional village as defined by the community of Waraka (village of ancestors, sacred stone and baileo, a traditional place for ceremonies), or a negeri administratif. The definition of negeri adat was legitimized during the colonial period in 1824 (Staatsblad) in order to define community groups and organize the legal and juridical system. A negeri administratif or local state government refers to a territorial or governmental unit ruled by a village (Purwanto 2013). A territory can have both recognitions. Tananahu, for instance, has an administrative territory but is not recognized by the adat, while Waraka or Liang have both types of territory (Figure 7).

\subsubsection{Adat and administrative territories}

On one hand, there is the territory recognized by the communities of the region as under the authority of the raja R.Y.B. Lailossa, known as Waraka's adat territory. It is bounded by the River Mala to the west, the River Nua to the east, by the sea to the south and by the Lumute Mountain to the north. It covers an area of more than 77,000 ha. On the other hand, there is the territory administratively recognized by the government, which covers an area of approximately 8,000 ha.

\subsubsection{Adat and administrative structures of governance}

\section{Structure of the negeri adat of Waraka}

The negeri adat of Waraka has been formed by four soa (clans) and is governed by the upu latu Lailossate. The organization of the village relies on different 


\section{Focus on history: Waraka's adat territory}

\section{Patalima and patasiwa}

Previously, Waraka was located in the Here Pulane Mountain, before moving to another mountain called KoliKolia. Its inhabitants were alipuru (without religion) and were part of the Wemale community, ancestors of Pata Lima division that remains in the center and eastern parts of Seram Island. On the western part of the island, delimitated by the Mala, Lau and Makina rivers from the south to the north, there is the second group of clans, Pata Siwa. The split between Pata Lima and Pata Siwa occured many years ago and led to distinct customs in relation to the number five (lima) and nine (siwa). Hence, a villager of Waraka that committed a fault will have to pay a bill of 5,555,555 rupiah, give five gongs and five pieces of cloth of $5 \mathrm{~m}$ for instance. The Patalima division was dominated by the raja Lailossate. In Wemale, a raja is called upu latu and this area is known as the upu latu Lailossate's territory (petuanan).

\section{Division North-South: Waraka and Marihunu}

Later on, the territory of upu latu Lailossate split in two. In the south, the upu latu Lailossate was established, while the north was ruled by the upu latu Kakilete Soununuhe, raja of Marihunu. The two territories were naturally divided by the Lumute Mountain.

Currently, the upu latu Lailossate's authority is recognized up to the north of the island. Indeed, all villages who share borders with Waraka keep the raja informed about any activity related to the use of land. They may also call on his assistance to act as a mediator in certain conflict situations between two parties. Nevertheless, he does not have the same rights there than what he has in the south, in his own territory of Waraka.

\section{From mountains to the coast}

At the end of the sixteenth century, Dutch rulers came to convert inhabitants of Seram to Christianity. They sent missionaries to the mountains, and Waraka villagers who converted moved down to the coast. They settled in Sapoa, where is now Waititai, a neighborhood with a majority of Muslim inhabitants, before moving to its current location. They called the village Waraka, "the ones who are waiting" in Wemale language, which means "the ones who are here and received the others, the newcomers". And indeed, they received seven other groups of people to who they distributed lands: Awaya, Apisano, Numalai, Italesia, Suawei, Liang and Tananahu.

These seven villages were ruled by "rich people" (orang kaya), that now call themselves raja. Nevertheless, according to members of the village's assembly there is only one "real" raja on this territory, and it is the one of Waraka. He gave them the lands where there are now established, and all activities concerning territory planning or land use and tenure have to pass by Waraka. Indeed, it is the only village that owns the three attributes that can attests of its sovereignity: the village ancestor (negeri lama), the sacred stone (batu pemali or patu astana in Wemale) and the baileo, the traditional and essential place for adat ceremonies. Nowadays, the upu latu of Waraka's territory is represented by the raja R.Y.B Lailossa and its territory is what we call Waraka's adat territory.

Adapted from interviews conducted with members of the village assembly, with the raja and with his father, the former raja, 2013.

actors whose role is defined by the traditional law. Apart from the upu latu there is the head of the adat (kepala adat), in charge of all traditional ceremonies, the tuan tanah, who is responsible for adat oath (pasawari), the captain (kapitan), in charge of security if there is a war, his assistant (malesi), the marinyo, mandated to transmit informations. The detail of Waraka's adat structure is shown in Figure 8.

\section{Administrative structure}

Representatives of the local state government's are identic to members of adat structure. The administrative structure of Waraka is shown in Figure 9.

In this system, the head of the village (raja), the secretary and two other representatives receive a salary from the State: IDR 2.3 million per trimester 


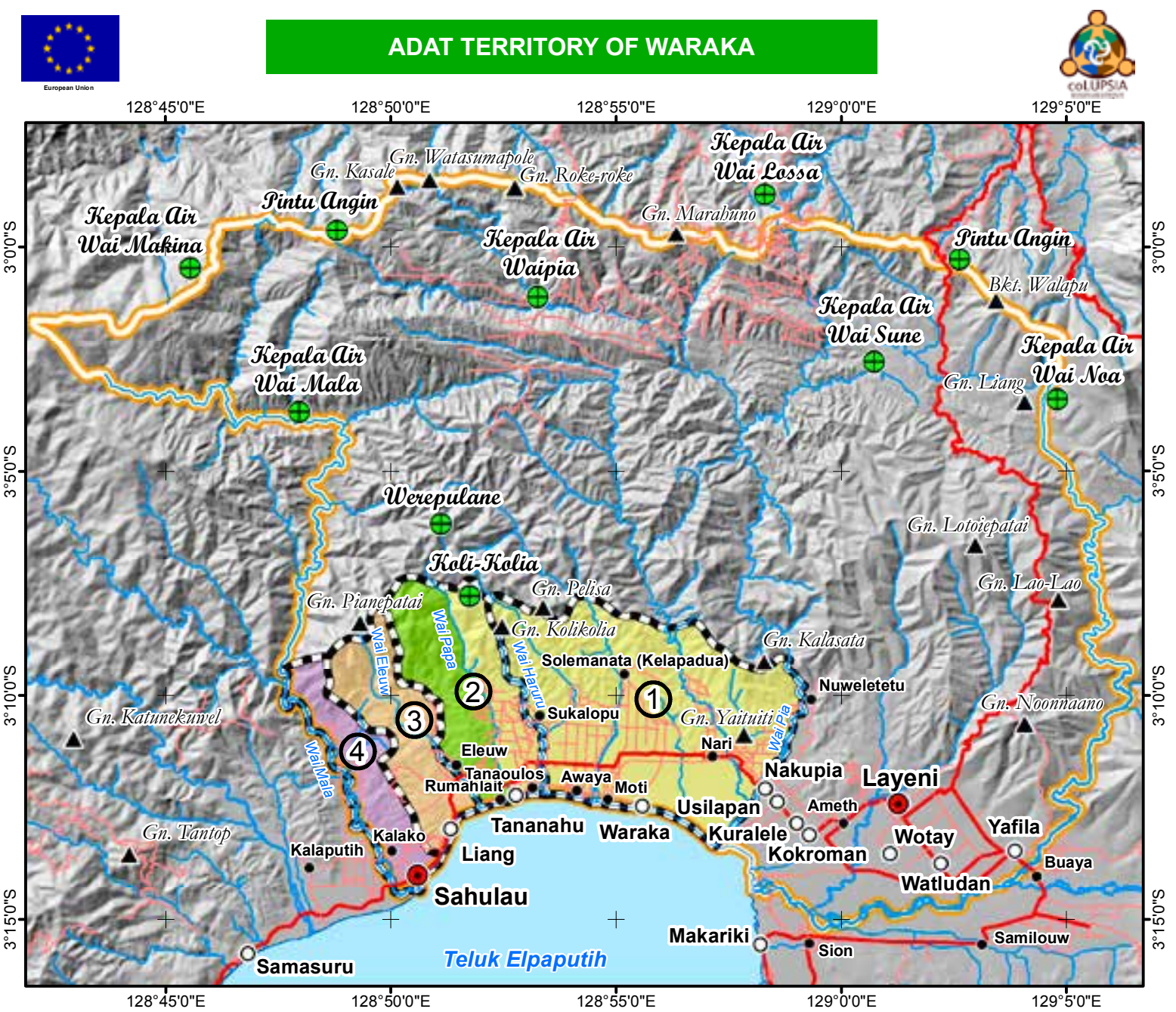

\section{Legend}

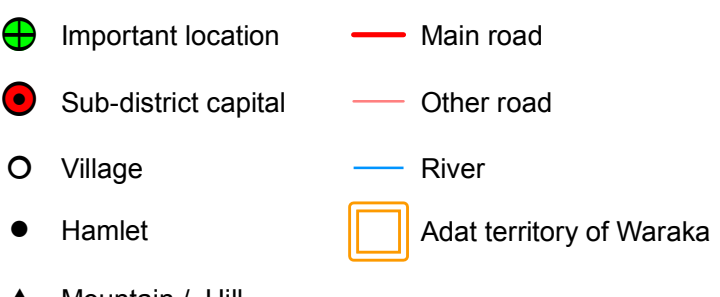

A Mountain / Hill
Adat territory currently used Administrative territory by the communities

\begin{tabular}{|c|c|}
\hline Waraka & (1) Waraka \\
\hline Rumahlait & - Tananal \\
\hline Liang & (3) Liang \\
\hline Sahulau & Sahulau \\
\hline
\end{tabular}
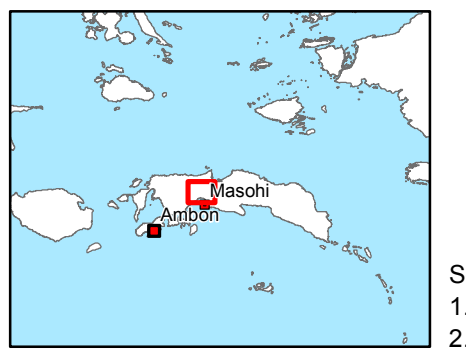

\section{Figure 7. Map of adat and administrative territories.}

For Waraka, two adat territories are represented: the one used daily by the community ("Actual use of adat territory") and a larger one ("Waraka's adat territory"), which is the territory where local communities recognize the authority of the raja R.Y.B. Lailossa. Classified as "important locations", there is "kepala air" which means 'spring' and "pintu angina", which means 'wind door' (specific point on the mountain which marks the separation between the north and the south). Map realized by Y. Persulessy and L. Ducos, with the help of D. Hadi (CoLUPSIA) after a semi-participatory mapping process with C. Lailossa and F. Wasilaini (members of the Village Assembly), with approval by the raja R.Y.B Lailossa, October 2013. 


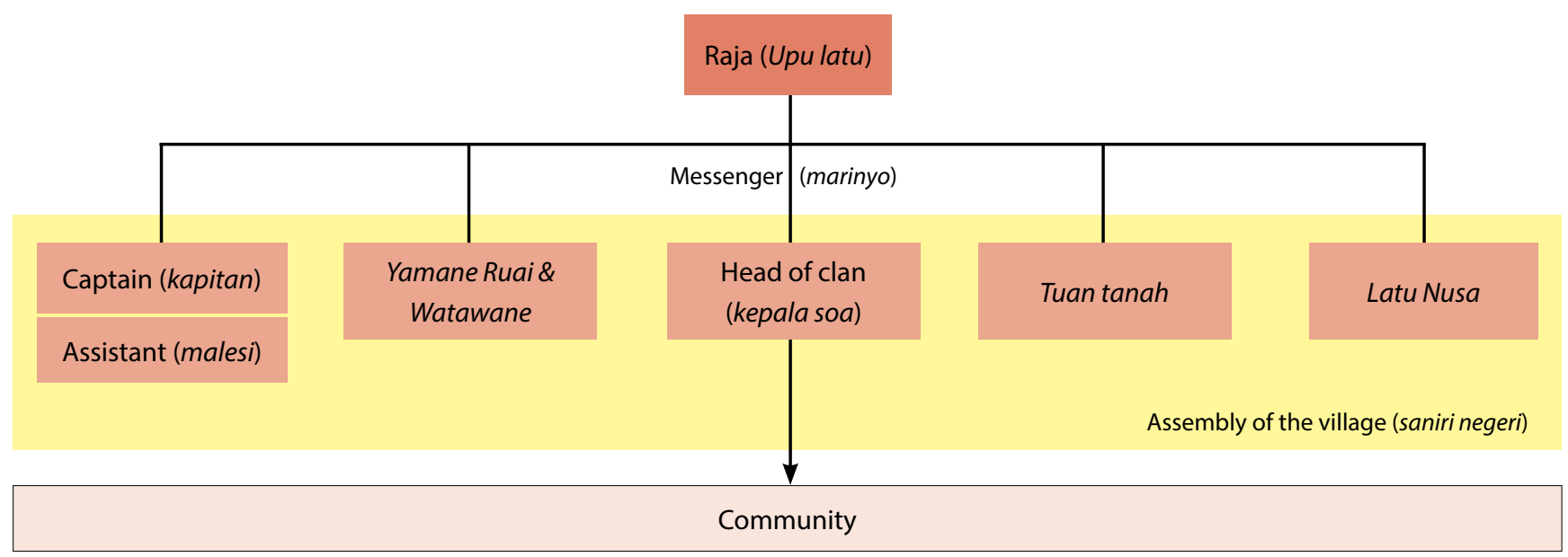

Figure 8. Adat structure of Waraka.

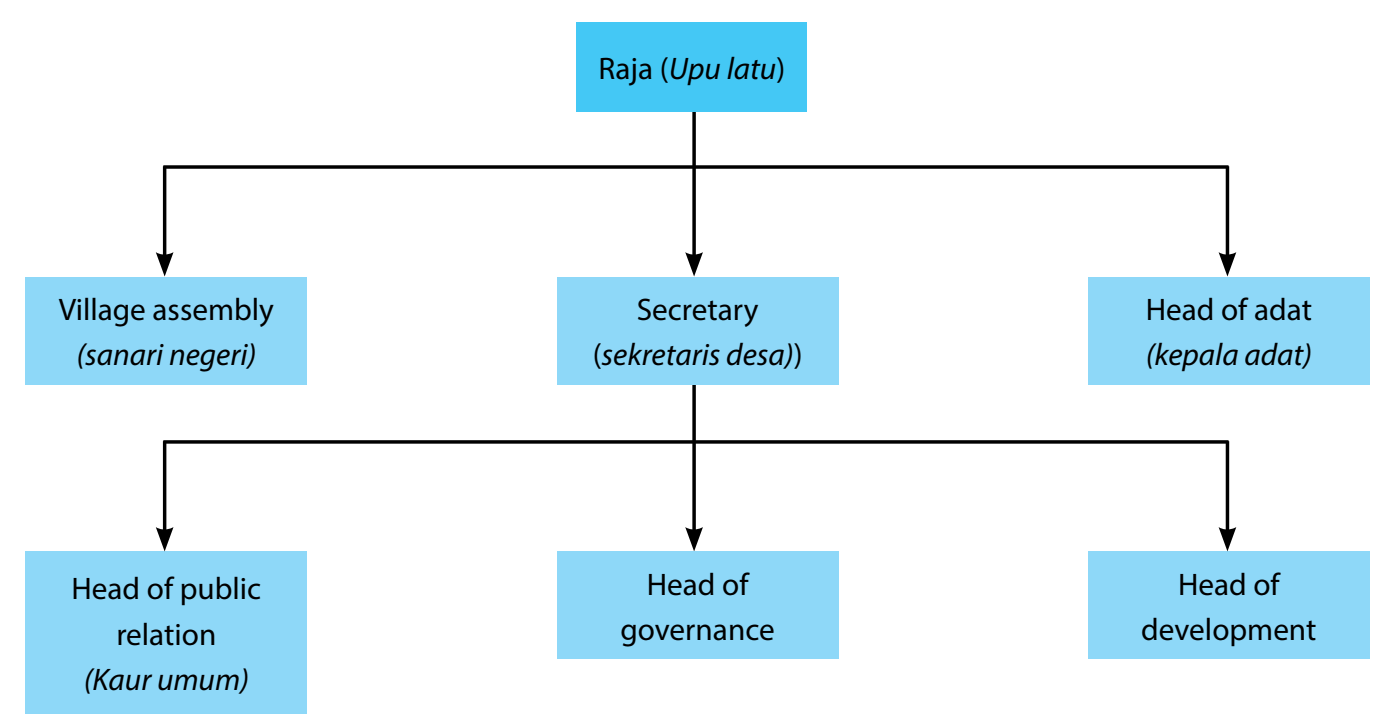

Figure 9. Adminsitrative structure of Waraka.

for the raja, IDR 2 million per month for the secretary and IDR 1.3 million per trimester for the other representatives. In addition, the village receives IDR 20 million per year.

\subsection{Governmental spatial planning in Waraka's adat territory}

The governmental reorganization of Waraka's adat territory started many years ago, passing through specific political times. Indeed, during the colonial period, the Dutch bought lands from heads of villages such as Amaya and Tananahu. Citizens of this second village were relocated to another area, still on Waraka's territory. Nevertheless, they were not given any rights of property and now they remain the only municipality that are still not recognized as having adat rights. Afterwards, these lands that the Dutch acquired were ruled by the Portuguese, before returning to Dutch rule, until nationalization in 1957. Figure 8 shows the RTRW-K (provincial planning) map used in Seram Island.

\subsubsection{Forest land}

\section{Official classification}

The 1982 Consensus on Forest Land Use (Tata Guna Hutan Kesepakatan or TGHK) divided state forestry land into five status classes: conservation (butan konservasi), protection (hutan lindung or HL), production (hutan produksi; HP), limited production (butan produksi terbatas; HPT) and conversion (butan konversi). In Seram Island, a forest land status 

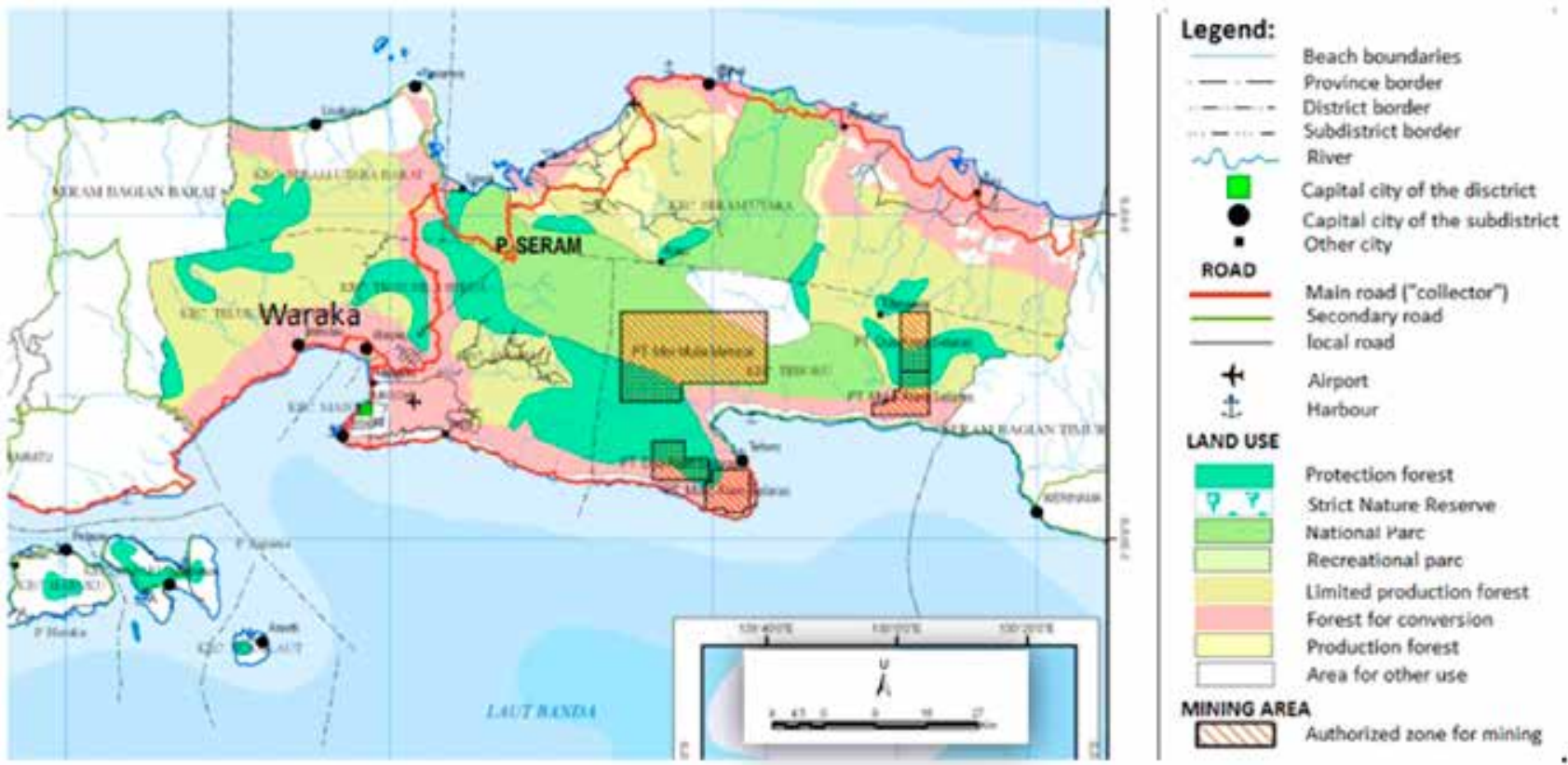

Figure 10. RTRW-K (provincial spatial plan) of Center Moluccas 2005-2028.

Source: BAPPEDA

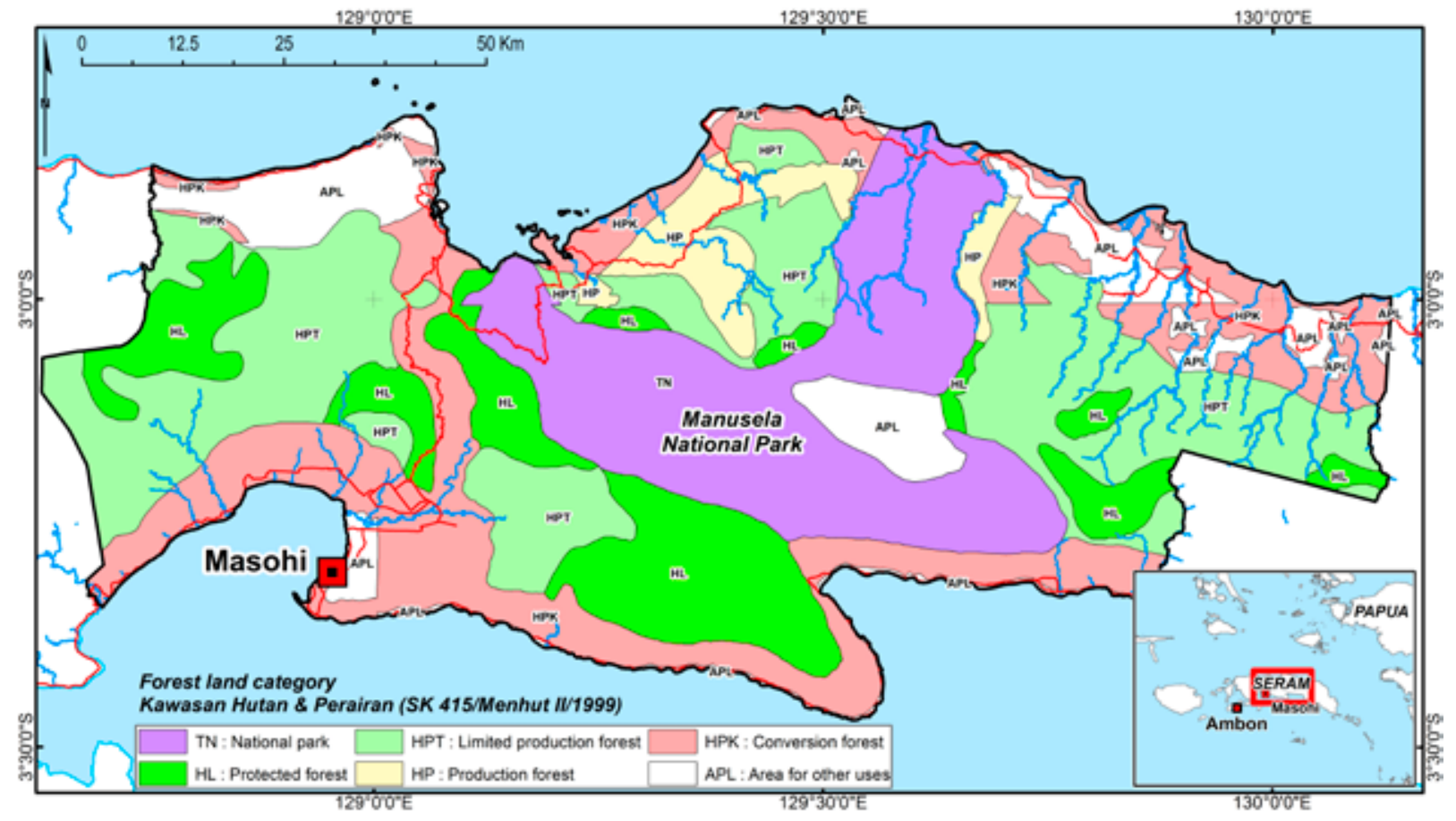

Figure 11. Forest land category allocation map for Central Seram (SK 415/Kpts-II/1999).

Source: Ministry of Forestry

category designation map was issued in 1999 called Peta Kawasan dan Perairan. It became the legal land forest designation reference in the province, with the five status of forestry land defined above and the rest being classified as "for other use" (non-state forest land).
There is one large conservation area called Manusela National Park. On the coast, there are major areas of forest lands for conversion, while in the inner lands there are forest lands for production and limited production. Above Waraka, the area is mainly classified as "forest of limited production". 


\section{Logging concession}

In Seram, the first significant commercial logging activity started in 1856 , during the Dutch colonial period (Ellen 1985), although the details of location and intensity of logging are unclear. After independence, logging activities were quite limited, until they began to increase in the 1970s and the early 1980s. At this time, about 1 million $\mathrm{m}^{3}$ a year were exploited in the Moluccas, and in 1989 there were 24 official forest concessions representing 2,593,000 ha (Ellen 1985).

This was the second time during the past decades that a private logging company entered the forest on Waraka's territory. The first company began operations in 1961, from the north of the island to the River Ruisi in the south. Its name was Kora-kora and a relative of the present company's director, Ferry Tanaya, owned it. In 2013, Albisia Priangan Lestari was granted a concession of 64,000 ha both at the central and district level for the utilization of timber forest products in natural resources (Hak Pengusahaan Hutan, $\mathrm{HPH}$, or IUPHHK-HA). Afterwards the company received a permit of exploitation, Ijin Usaha Penebangan Kayu or IUPK. To be able to gain these authorizations, the company needed to show that Waraka's raja agreed to the concession and exploitation. This agreement was easy to obtain as the company has enjoyed close relationships with the family of the raja for many years. Together, they conducted the apapu — the adat traditional ritual that consists of asking the permission of ancestors before entering the forest - and it was carried out well before the land-use rights concession was obtained.

Finally, the concession covers an area that starts between the Haruru and Pia rivers in the south and includes the land up to Hurale in the north. Hence, according to the land use allocation map SK 415, it is located in a "limited production area". However, if we use the more precise maps designed by CoLUPSIA, then the territory exploited by the APL company is under the category of "watershed protection forest".

\subsubsection{The case of the PTPN XIV company}

The Perseoran Terbatas Perkebunan Nusantara XIV

Persero Ltd. company (PTPN XIV) is a state-owned company that was established in Teluk Elpaputih subdistrict in the 1980s to produce coconut, cocoa, rubber and, to a lesser extent, nutmeg. They were given land-use rights for 30 years that ended on 31 December 2012 and they are now looking for an extension of their land-use rights. In order to obtain this renewal, they have to attest that the five villages where the company's plantations are located agree to extend this permit.

\section{History}

According to the company's profile, Mr. Borman and Mr. Jansen bought 14,000 ha of lands from Moses Laturiuw and Elpaputih Raja, somewhere between the Rivers Pia and Mala. These lands were subsequently sold four times, before becoming the property of the state during nationalization in 1957 under the status of erpracht konsesi (long-lease).

After nationalization, a public company or Badan Usaha Milik Negara (BUMN), called the Perusahan Perkebunan Negara (PPN) was established on these lands. Its name changed a few times before becoming PNP XVIII in 1982, the year of the World Bank's intervention that provided funds to establish new coconut plantations. These plantations established had a sizeable socioeconomic impact on the region. In 31 March 1982 the status of the land changed; from erpracht it became a concession or Hak Guna Usaha (HGU) for a period of 30 years that ended in 2012.

\section{Concession renewal}

The company now wants to extent the HGU. To do so, Agraria, the Department of Agriculture asked them to obtain the agreement of Sahulau, Liang, Tananahu, Samasuru and Waraka, the villages of the five territories on which the PTPN XIV has plantations. However, relationships between these villages and the PTPN XIV are difficult and local people denounce company practices, such as salary swindling and land grabbing. However, Waraka villagers' view is that people depend on their job at the company and agreed to extend the contract. The PTPN has to fulfill a few conditions for extension of the contract: all employees of Waraka must get a long-term work contract and the company must be responsible for the education of all students who wish to enter university up to master's degree level.

\section{Recommandation of the regent}

On the east, the border of the PTPN's concession or HGU is represented by the Nari River. However, the regent made a recommendation which allows the company to plant another area of 616 ha beyond this border. This additional zone has been established between the rivers Nari River and Pia River, the 


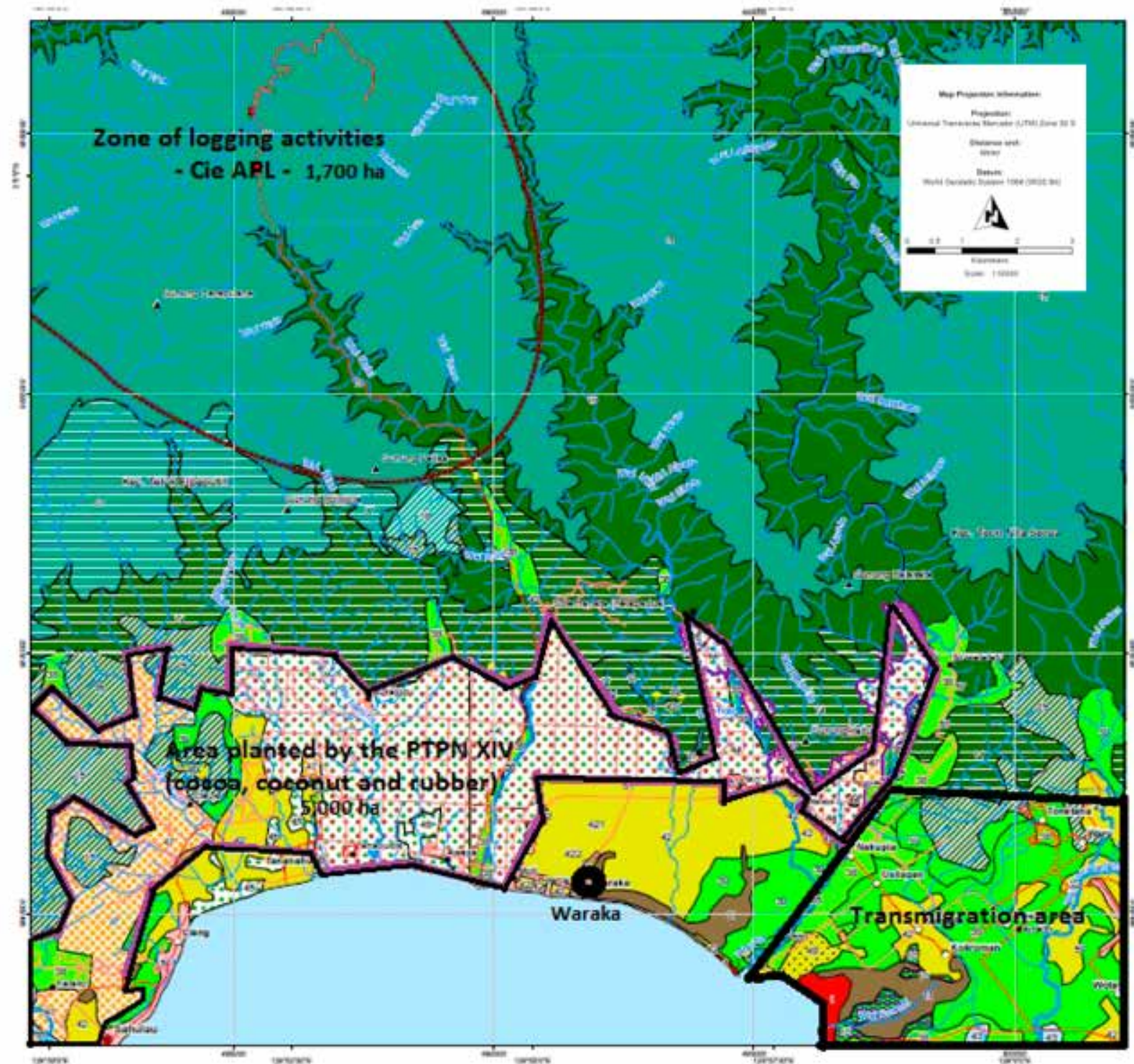

\section{Legend}

? Clove garden

* Local logping sile

[- Log pond

* Mining

Q. Moed tree garden Cempedak

(5) Sanmiat

Q Main base camp logging comoany APL.

I Secondary base camp logging company APL

4 Local logping company (Waraka)

- District capital

- Sub-district capta

O vilage

- Hamlet

- Warakars neighborhood
A Mountain i ra

- Regency boundary

- Sub-datrict boundary

- Coloctor Rosd

- Other Road

- Local Rood

.... Lopoing road

- Rover

$\square$ Zone Under Recommendation of Bupasi

Zone Logging Activities

1. Margrove
10, Secondary regrower swamp forest (Belukar rawa)
11, Sago swamp
13, Lowland forest ( $<300 \mathrm{~m}$ )
14, Logged over lowtand forest__ depleted
T7 15, Overboged lowland forest_ very depleted

16, Hal forest $(300-800 \mathrm{~m})$

17. Logged over hali forest

18. Overlogged hat fores:

38, Shrub or open area (aong)

39. Secondary rogrowth forest (aong tua / ewang)

42. Mutiple cropping

Figure 12. Simplified map of land use planning in Waraka's adat territory.

Source: CoLUPSIA project, ground check Y. Persulessy and L. Ducos (2013) 
eastern limit of Waraka territory. It is covered by coconut and cocoa plantations.

\section{Actual situation}

To date, PTPN XIV have not taken into account any reclamation of the community. Actually, they consider that since nationalization in 1957, the land is the property of the state, and even if they were to stop their activities, the land would not return to the local communities. Hence, the raja of Waraka decided to implement a sasi on the land planted by the company on Waraka's territory. This means that the production cannot be harvested, and when it is, part of the benefits will be reserved for the village (sasi adat) or for the church (sasi greja). On 24 August 2013, they set up of signboard forbidding the harvest of the plantations. Nevertheless, up to now the company has ignored the sign and has continued production. They recently opened new areas to establish plantations of rubber trees in the area of 616 ha that is not included in the HGU. That may show that they do not intend to stop their activities yet. In Tananahu, villagers cut 30 trees that the PTPN XIV had recently planted. The confrontation is escalating and at the beginning of September it led to the intervention by soldiers and the police force (but the reasons behind this remain unclear).

\subsubsection{Transmigration area}

As an initiative of the transmigration program, ${ }^{2}$ the State incited companies such as PTPN XIV, a cocoa and rubber company from Sulawesi to set up on the territory of Waraka. They mobilized a workforce from Ambon, the capital city of Maluku and from Java and other islands. This implantation lead to the establishment of new hamlets such as Solemanata (Kelapa II) and Moti.

In a nutshell, many villagers attracted by job opportunities or better conditions of life settled in the eastern part of Waraka adat territory. Through this governmental programme they were given two ha of land per head of family (kepala keluarga).

2 The transmigration program was an initiative of the Dutch colonial government in the early nineteenth century, later continued by the Indonesian government, to move landless people from densely populated areas of Java island to less populous areas in Indonesia. The stated purpose of this program was to reduce the considerable poverty and overpopulation on East Java, to provide opportunities for hard-working poor people, and to provide a work force to better utilize the natural resources of the outer islands (Leinbach 1989).

\section{A necessary clarification of rights of property}

However, these villagers did not receive any land certificates and today they are the victims of land grabbing. Indeed, some individuals from other villages such as Sepa have already tried to use or to sell land in this area that was attributed to the transmigrants. Thus, in July 2013, 9 of the 18 rajas governing this part of Waraka adat territory asked the raja of Waraka for a document attesting that he gives his agreement for them to obtain the rights of property that they are claiming. With this paper, the rajas will be able to present themselves to the governor of Maluku in Ambon and ask for the certification of their rights of property, which will eventually protect them against land grabbing and other abuses.

\subsubsection{Mining}

As shown on the spatial planning map (Figure 10), an area officially allocated for mining exists in the eastern part of Seram, but there is no allocation of this kind in Waraka territory. However, locals have a few spots for exploration for mining in the hills. There are not located in a defininte place but are spread out over the territory, quite close to Waraka (at more or less $5 \mathrm{~km}$ maximum from the village). Gold has never been found up to now. Villagers did not mention this activity. It was only during a field trip that related material was found. Figure 13 summarizes the landuse planning situation in Waraka's adat territory.

\subsection{Traditional land-tenure system}

\subsubsection{Control of land tenure by the raja}

The authority of R.Y.B. Lailossa or upu latu Lailossate is dominant in the region. As the head of Waraka since 2009, the raja has for main objectives for

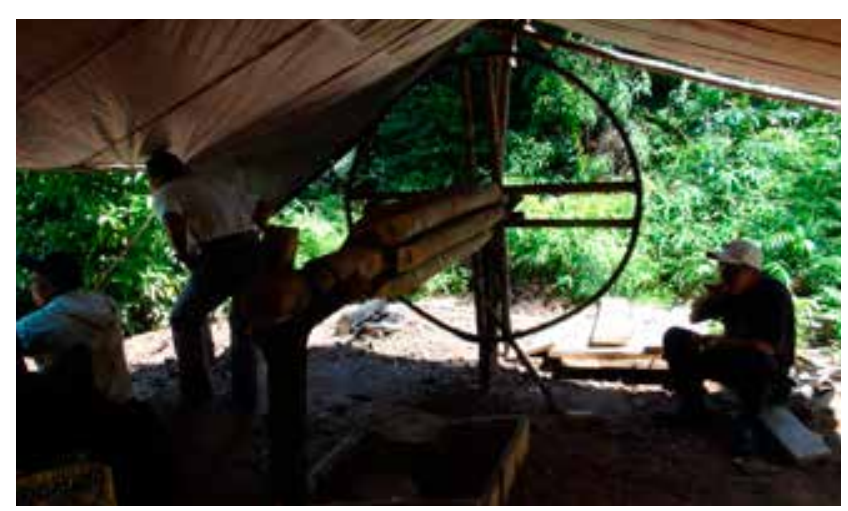

Figure 13. Prospecting material for local mining in Waraka. 
land management. He is open to host all kinds of exploitation, providing that there is a benefit for the population and provided it will not (completely) destroy the resources. The raja is willing to deliver land-use rights concessions to produce cocoa, coconut and rubber, but up to now he has refused to allocate lands for palm-oil plantations and pasture lands since he believes that it will have negative impacts on the land and compromise the production of sago (Metroxylon sagu), the basis of Maluku inhabitants' staple food.

The upu latu Lailossate also control the lands' sale. First, he used its authority to set a prohibitive price of IDR 10,000 per $\mathrm{m}^{2}$ (about US\$ 1 per $\mathrm{m}^{2}$ ) on the land. Second, if a farmer wants to release part of his property because he is in need, he must discuss it with the raja first so they can look for an alternative solution to meet farmer's needs. To force farmers to have this preliminary discussion with him, the raja compiles all villagers' certificates of property at his office, so that they cannot use them without asking first. The upu latu decided to take control over this lands' sale when he noticed that many farmers who had received rights of property had quickly sold part of their land to external investors.

\subsubsection{Individual property}

There are three different ways of acquiring lands individually in Waraka: villagers can buy it (pembelian), get it from the village (village attribution or pemberi negeri) or inherit it (warisan).

\section{Village attribution (pemberi negeri)}

When a farmer wishes to set up in Waraka, he receives 1.5 ha of land from the village. Then, to obtain a certificate of property, the new citizen has to show a sincere commitment to the community (through participation in village activities, meetings attendance, etc.) and actively manage the land that he has been given. Usually, they get 1 ha and an additional 0.5 hha after 6 months if they made good progress. Eventually, they can get a certificate of property from the Ministry of Agriculture (Agraria). To date, about a hundred certificates have been delivered for part of the lands located below the main road.

\section{Inheritage (warisan): A patriarchal system}

The system of transmission is patriarchal - the inheritance is given from father to son. There are no distinctions made between brothers; all receive an equivalent area. When the father dies, the eldest son obtains the rights to manage the property; he decides about land attribution, in an equitable way, even if he returned to his mother's clan, i.e. even if he took back his mother's clan name. This change may happen for a number of reasons. The main one is that the husband that has to pay a debt cannot afford it, and consequently their first son or daughter will be arken. He or she will take his or her mother's clan name. Thus, when there is an inheritance, a land can be divided in equal parts. Nevertheless, a father can also decide to establish a dati.

\section{Dusun dati: "Eat together" or makan bersama}

A dusun is a plantation of palm and fruit trees such as coconut, banana, nutmeg, durian or rambutan trees that may also contain timber, arbusts and other plants. They can be totally or partially planted. To give a dusun the property of a dati means that the property is sealed; the land is not divisible anymore. Hence, all members of a family that have rights to this plantation; they must share the benefits in turn, according to the order defined by the father or the elder son. The next generation cannot modify this rule of reserve anymore. This system is called "eat together" or makan bersama and it is often used on dusun located in the mountain or in dusun sago.

Thus, the decision of a farmer to turn his plantation into a dati means that the dusun will stay indivisible for generations; this system helps to reduce land fragmentation and decreases the number of future conflicts related to inheritance.

\subsubsection{Jemaat: Church's gardens}

In Waraka, almost $80 \%$ of the population is Protestant (18\% are Muslim and $4 \%$ are Catholic). The church is one of the most important institutions of the village and organizes many activities that form the pattern of citizens' lives. It owns part of the fields in Waraka area. They are collectively managed by the community, which is organized into units or neighborhoods. Each of these units is in charge of cleaning, planting and harvesting a plot. The church gets the benefit but farmers can also use part of the area to farm for their own consumption. Also for each dusun (plantation or mixed forest garden), a farmer must give one of his coconut trees to the church (tanaman salip/salip plant).

\subsubsection{Lands of Waraka (tanah negeri)}

All lands between the Haruru River (east) and Pia River (west) belong to Waraka (tanah negeri). However, many parts of this area are considered to 'belong' to individuals. There individuals do not have any kind of land certificate but since they managed a 
plot for many years, they are recognized as the 'owners' of this piece of land. Although these rights of property are not officially registered, they are transmitted from generation to generation. Today, the raja does not attribute certificates anymore to prevent selling of land.

This section presented the traditional land-tenure system of Waraka. The next one develops the second part of the first objective of the study - to identify and map the traditional land use of the village.

\subsection{Land use}

\subsubsection{Traditional agriculture and agroforestry systems}

The maps that were drawn during the participatory mapping exercise helped me to understand that the community principally uses two zones: one located close to the main road, between the coast and the

Waraka's traditional land tenure system is:

- a system of both public and private ownership with lands that belong to the church (jemaat), to the village (tanah negeri), to families (dusun dati) and to individuals (private properties)

- a system controlled by the raja, who decide to attribute and sale land or not

- a patriarchal system main road; and one in the hills, to the north of the PTPN's commercial plantations, which is mainly used for clove production. However, as the areas of their properties are generally less than a few hectares, participants were not able to give more details about the location of the different land uses (food crop field, mixed tree gardens, cocoa plantations, etc.) that they had defined during their collective discussions. Eventually, a land-use map was established, based on the CoLUPSIA map obtained with the analysis of 2009 satellite imagery. The CoLUPSIA map was improved thanks to GPS and observation data collected during various field trips.

\section{Composition}

The territory of Waraka's community is composed of:

- Home gardens: Small pieces of land called kintal, close to the houses, where they plant either annual or perennial crops. See Appendix 3 for more details.

- Food crop fields: Called kebun in Indonesian or weneu in Waraka; they are a source of staple food and a source of cash income for Waraka inhabitants. They are generally around $0.25-0.5$ ha in area, sometimes up to 1 ha. See Appendix 4 for more details and Appendix 5 for a full list of species that are found in these food crop fields.

Table 2. Mean incomes for staple and non-staple food from the Waraka food crop fields.

\begin{tabular}{|c|c|c|}
\hline Kind of product & Product & $\begin{array}{l}\text { Value of production per } \\
\text { household (IDR/year) }\end{array}$ \\
\hline \multirow{3}{*}{ Staple food } & Manihot esculenta (cassava) & 362,163 \\
\hline & Colocasia esculenta (taro) & 541,037 \\
\hline & Dioscerea sp. (yam) & $1,940,000$ \\
\hline \multirow{6}{*}{ Non-staple food } & Vegetables & \\
\hline & $\begin{array}{l}\text { Spinach (Amaranthus spp.), water spinach (Ipomoea aquatica), } \\
\text { mustard greens (Brassica sp.), eggplant (Solanum melongena) and } \\
\text { chili (Capsicum annum, Capsicum frustescens) }\end{array}$ & $\begin{array}{l}5,125,000 \\
\text { (US\$ } 455)\end{array}$ \\
\hline & Fruits & \\
\hline & $\begin{array}{l}\text { Duku/langsat (Lansium domesticum), durian (Durio zibethinus), } \\
\text { orange/lemon (Citrus sp.), cucumber (Cucumis sativum), banana } \\
\text { (Musa spp.) and rambutan (Nephelium lappaceum) }\end{array}$ & $\begin{array}{l}5,786,423 \\
\text { (US\$ } 513 \text { ) }\end{array}$ \\
\hline & Beans & \\
\hline & $\begin{array}{l}\text { Green beans (Phaseolus lunatus), peanuts (Arachis hypogaea), } \\
\text { soybeans (Glicyne max) and string beans (Vigna unguiculata) }\end{array}$ & (US\$ 772 ) \\
\hline
\end{tabular}

Conversion of IDR into US dollar: US\$1 = IDR 11,341

Source: http://www.asie360.com, accessed 31 October 2013. Adapted from Liswanti (2013) 


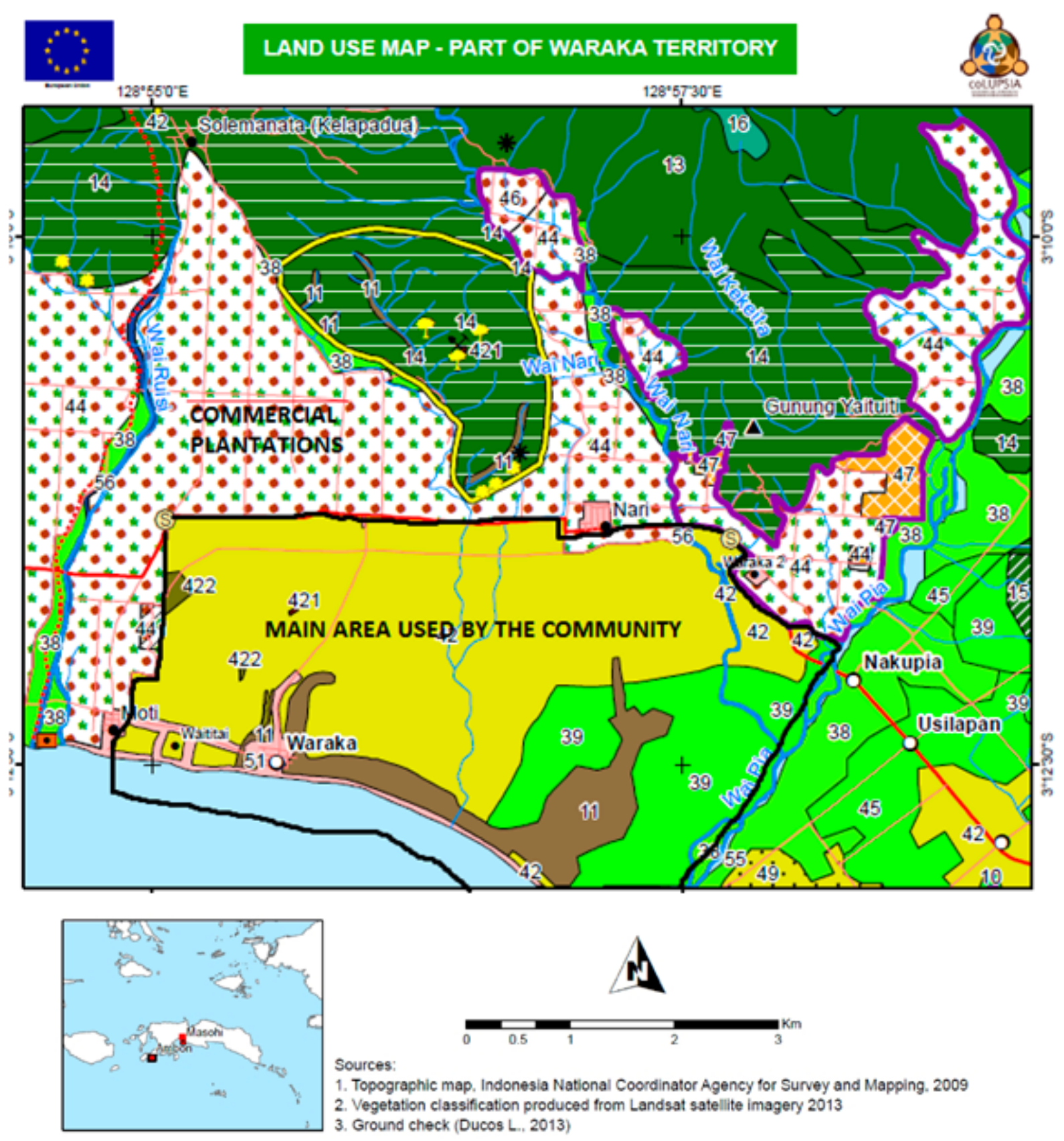

\section{Legend}

\begin{tabular}{|c|c|c|c|}
\hline Clove garden & - Colector Road & Zone Under Recommendation of Bupati & 42, Multiple cropping \\
\hline Local logging site & - Other Road & ] Zone of mixed tree gardens, previously under HGU & 421, Garden Jemaat \\
\hline Log pond & — Local Road & 57, Cloud & 422, Tanah Negeri \\
\hline Mining & "n" Logging road & 10. Secondary regrowth swamp forest (Belukar rawa) & 44, Cococnut estate (Coconut - cacao) \\
\hline Mixed tree garden Cempedak & River & 11, Sago swamp & C. 441 , Zone damaged by forest fires \\
\hline Sawmill & & 13, Lowland forest $(<300 \mathrm{~m}$ ) & 45, Coconut plantation \\
\hline Village & & 14, Logged over lowland forest__ depleted & 46, Cocos plantation \\
\hline Hamlet & & 15 , Overiogged lowland forest__very depleted & 47, Rubber estate \\
\hline Waraka's neighborhood & & 16 , Hill forest $(300-800 \mathrm{~m})$ & - 49, Food crop field \\
\hline Mountain / Hill & & 38, Shrub or open area (aong) & 51 , Settlement \\
\hline & & 39, Secondary regrowth forest (aong tua / ewang) & 56, Water body \\
\hline
\end{tabular}

Figure 14. Land-use map: Part of Waraka territory.

Source: Ducos (2013) 
Fruits and vegetables are a major food source and a source of income: they represent a value of IDR 5,125,000 (fruits) and IDR 5,786,423 (vegetables) per year (value of subsistence included). This data has been collected from a group of 30 households (out of 440) and is not representative of the entire village. There is a bias, especially with regard to the species cited (incomplete list). To compare with national levels, the minimum salary in Indonesia is about IDR 673,000 month (US\$60) and the mean salary is about IDR $1,200,000$ per month (US\$ 118), or IDR 8,076,000 year and IDR $14,400,000$ year, respectively (Export Entreprise SA 2013). The poorest quartile of Waraka population (Table 3) earn IDR 5 million.

- Coconut and cocoa tree plantations: Mixed and single crop plantations of cocoa (Theobroma cacao) and coconut trees (Cocos nucifera) cover a great part of Waraka's territory (Figure 14). Since 1982, commercial companies have entered the territory and widely influenced the local community who increased the total area of its plantations (exact area unknown).

The community's plantations can be divided into three categories: single-crop farming of coconut, single-crop farming of cocoa trees and mixed plantation of cocoa under coconut trees. All of these categories will also have banana trees (Musa spp.) in the sublayer. Banana is a common species that provides cash income and fruits for selfconsumption, among other uses (see Table 2).

- Coconut plantations are the main source of cash income for farmers, with a mean income per household of almost IDR 8,870,000 per year (US\$ 787) in Waraka. Farmers can sell coconut fruits (at between IDR 300 and 700 per fruit) but they usually make copra first. This process consists of extracting and drying the old flesh. Further, although it is not a daily-consumed product and its quality is low, cocoa is another main source of cash income for the community, after coconut and cloves. Farmers sell it dry (between IDR 17,000 and 29,000 per kg (US\$ 1.53 and 2.61 per kg), or wet (IDR 3,000 or US\$ 0.27 per $\mathrm{kg}$ ), if they do not want to, or cannot dry it, because of climatic reasons.

- Rubber plantation: Only one villager, Pak Hatib, grows rubber trees (Hevea brasiliensis), on a area of 1 ha. See Appendix 7 for more details.

Table 3. Mean income by income group across villages (IDR/year).

\begin{tabular}{lc}
\hline Perennial crops & Mean income per household (IDR/year) \\
\hline Cocos nucifera (coconut) & $8,867,333$ (US\$ 783) \\
\hline Syzygium aromaticum (clove) & $5,000,000$ (US\$ 440) \\
\hline Theobroma cacao (cocoa) & $2,826,333$ (US\$ 249) \\
\hline Myristica fragrans (nutmeg) & 924,000 (US\$ 81) \\
\hline Hevea brasilensis (rubber) & $?$ (only 1 household) \\
\hline
\end{tabular}

Source: Liswanti et al. (2013)

Table 4. Mean income per household for each main crop in Waraka.

\begin{tabular}{lccccc}
\hline Grouping & \multicolumn{5}{c}{ Mean household income by group (arp/year) } \\
\hline & Amahai & Sahulau & Tamilouw & Waraka & Watludah \\
\hline Poorest & $5,986,857$ & $5,937,244$ & $3,606,999$ & $5,075,732$ & $5,150,439$ \\
\hline Second 25\% & $13,085,011$ & $10,609,000$ & $12,171,688$ & $12,778,028$ & $12,504,252$ \\
\hline Third 25\% & $21,706,788$ & $21,223,437$ & $20,910,852$ & $19,099,002$ & $22,393,333$ \\
\hline Richest & $42,599,374$ & $89,122,457$ & $108,206,196$ & $52,547,382$ & $33,660,000$ \\
\hline
\end{tabular}

Note: Cash income includes income from agriculture, forest, fish, husbandry and employment. Subsistence income or value has been estimated using market prices and production/consumption levels. Cost of production have not been subtracted so these figures represent gross income values for cash and subsistence. Subsistence is focused on production of agricultural commodities and some forest resources, harvested for own consumption. 
- Mixed tree gardens are traditional agroforestry systems defined as "gardens in which few or no annual crops are grown, and which have a permanent close canopy together with a closed forest structure" (Monk et al. 1997). There are also called dusun, which are described as "complex agroforestry systems" that can be "characterized by the coexistence of cultivated trees and sometimes wild plant species" (Kumar and Nair 2004), or as "an example of forest gardens, dominated by coconut tree (Cocos nucifera) or nutmeg tree (Myristica fragrans)" (Kaya et al. 2002).

In Waraka administrative territory, villagers manage two categories of mixed tree gardens or dusun as defined above. One category concern dusun in lowlands, close to the village on the south side of the main road ("Multiple cropping" area no. 42, Figure 14). They are often dominated by coconut trees (Cocos nucifera) and cocoa (Theobroma cacao) and nutmeg (Myristica fragrans). They have many fruit trees such as durian (Durio zibethinus) and duku (Lansium domesticum) (See Appendix 8 for details). The second category includes mixed tree gardens located in the steep hills on the north side of the main road, behind the plantations of the cocoa company. Today these are mainly characterized by their production of clove (See Appendix 8 for details).

Sago plantations are one kind of dusun that can be found anywhere in Waraka's adat territory where there is enough water such as in swamp area or rivers. The sago palm (Metroxylon sagu), liki or liki patai in Wemale language, is the main staple food of Waraka inhabitants. For many years, farmers planted this palm close to the village, to avoid being totally dependent on wild sago. Its cultivation does not require large areas, as rice production does for instance, and it does not need a specific system of irrigation (in Waraka they do not produce rice at all). Thus, in Waraka dusun sago is one of the most important traditional land-use systems and this has direct impacts on the landscape of the region. See Appendix 11 for more details about sago production in Waraka.

\section{Management}

Slash and burn cultivation: Masohi system In Waraka, villagers use slash and burn cultivation through a system called masohi (gotong royong in Java). To open a forest (bankar), dwellers join in a

\section{The main characteristics of Waraka's mixed tree gardens are as follows.}

- They are usually located within $5 \mathrm{~km}$ of the village.

- They have a high diversity of planted species. This means that farmers can adapt to market's fluctuation easily and get a regular income, even if there is a problem with price or the invasion of a pest or disease on one species. This largely reduces villagers' vulnerability.

- Apart from fulfilling specific economic, social and cultural needs of the individual owners, these agroforestry systems provide biological conservation and carbon sequestration (Kumar and Nair 2004).

See Appendix 10 for the land-use profile in the first $7 \mathrm{~km}$ of Waraka.

common effort to clear and burn a specific area that will then be divided into personal plots (usually about 1.5 ha each). This system (masohi) can also be applied to other kinds of activities such as the construction of houses, or in village's requirement to clean home gardens and bamboo hedges or to fix a bridge, for instance (a kind of volunteer work called bakti). Usually, villagers keep a food crop field for 4-7 years before planting fruit trees (coconut, banana, cocoa, nutmeg) to transform the area into a dusun. If the food crop field is not planted but abandoned, it becomes a secondary regrowth forest that will be open again 15 or 20 years later.

Sasi

Sasi is a generic name for a family of institutions, laws and ritual practices that regulate the access to resources on land, coastal reefs and rivers (Zerner 1994). It is a system used by the community to control the production of a tree or a plantation and manage the benefits that they get from this production. A plantation under sasi cannot be harvested before the time defined by its owner. In the case of a sasi jemaat, part of the benefits from the sale of the production is given to the church. In the case of a sasi adat or sasi negeri, part of the benefits will be given to the village. Mostly applied to coconut and cocoa plantations, it is an efficient way of controlling production: nobody dares to steal the fruits of trees under sasi, because of the related sanctions defined by the adat or, in the case of a religious sasi, "because of their fear of God's sanctions". This last case has been described by Sasaoka and Laumonier (2012) as "based on a supranatural enforcement mechanism". 


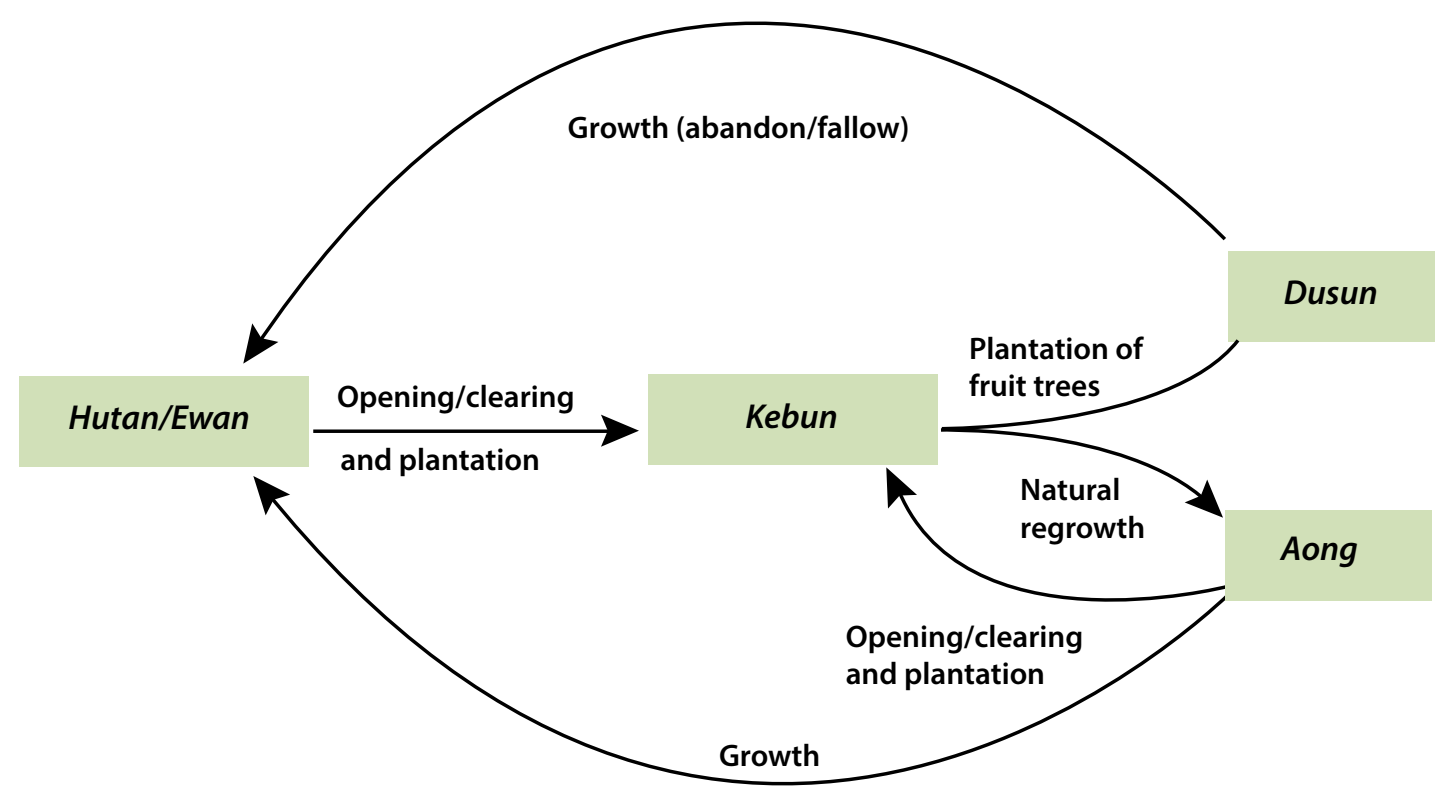

Figure 15. Slash and burn cultivation in Waraka, from forests to dusun.

Note: Hutan or ewang refers to a forest where there has been no activity for decades, in the hills or in mountains. A secondary forest (forest logged many years ago or recently but slightly, former food crop field or dusun) is known as an old aong or even ewang if there are trees of large diameters. When a farmer abandons a food crop fields (kebun), the area becomes an aong first.
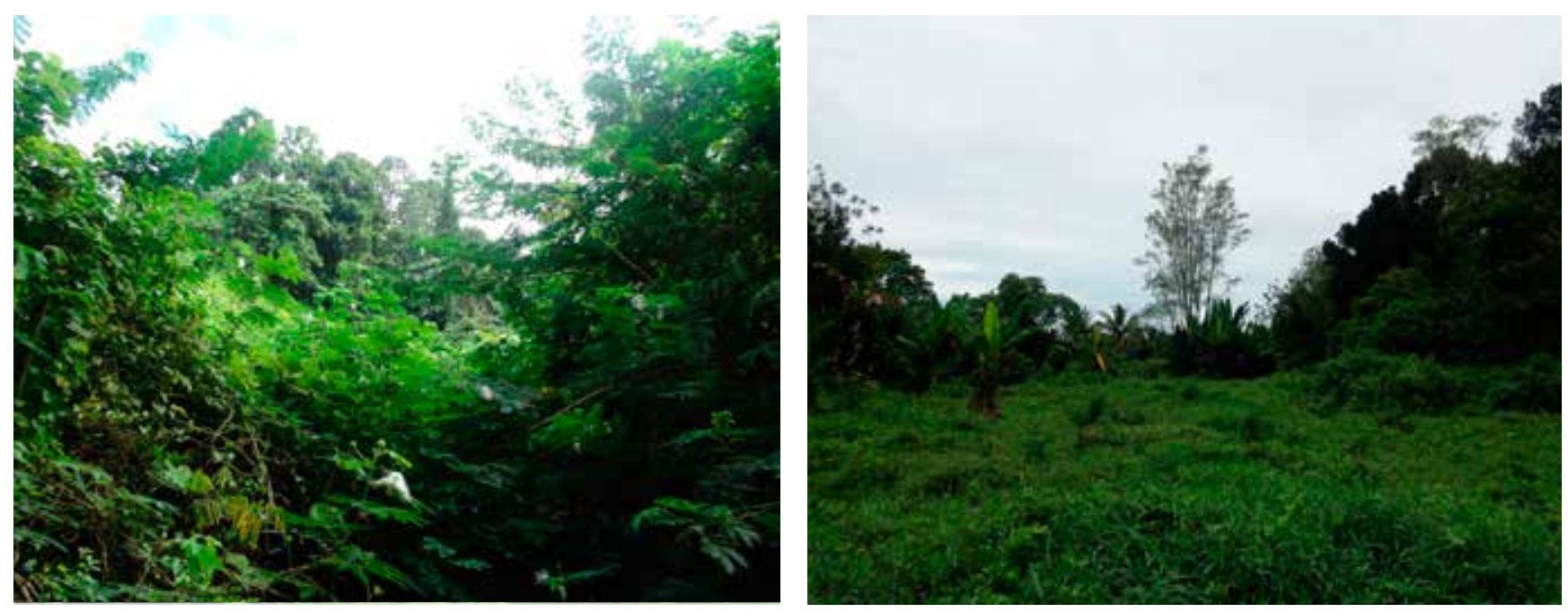

Figure 16. Left: Old aong, at the top of a hill. Right: Aong that will be planted with more fruit trees soon.

\section{“Win-win" system}

Most farmers work on their own, with help from their children or relatives. However, some allow outsiders who do not have their own land (from the transmigration area, for instance) to farm on their mixed forest gardens. These farmers can choose to give part of their production or not to the workers.

\section{Chemical use}

Farmers don't use pesticides - mainly because of the cost - except if they want to sell their production in Masohi. Plant Katalis (for chilli and tomato), Bion M (pesticide), Round up or Gramoxone (herbicides) and Petrogenol (to make traps for pest control) are some of the products currently used. Usually, the few farmers that use chemicals are former employees of the cocoa company, where they have attended special workshops to learn how to use pesticides.

\subsubsection{Traditional use of forests}

In Wemale, the local language, a forest is called weisie while in Bahasa Indonesia it is called hutan or hutan rimbah for a primary forest. In this 
section the use of forest resources by the community is presented.

\section{Sacred and protected forests Sacred forest}

In Waraka, some forests are considered to be sacred; they are situated in the former location of the village, in the mountains of Herepulane and Koli-Kolia. Nobody is allowed to enter these places, except when the traditional and extraordinary ceremony takes place when a new raja comes to power or when village council performs the adat oaths prayers called pasawari.

\section{Protection and conservation areas: hutan lindung and National Park}

Hutan lindung or "watershed and soil protection forest" is a classification for forest designated to protect its natural resources such as watershed or soil fertility (Law No. 41/1999). Local communities can use a hutan lindung "as long as it doesn't disturb or damage the main functionality of the area" (Article 26) i.e. harvest non-timber forest products (NTFPs) such as fruits and honey. There are two protection forests in the mountains of Waraka territory (Figure 10), and one on the coast, close to the Pia River (mangrove). Villagers are clearly aware that this classification means that it is forbidden to harvest or damage the habitat. Nevertheless, many of them have reported a fast and significant decline of the mangrove area, compared to a few years ago. According to them, it is mainly due to the illegal logging carried out by other people, from Masohi in particular. This logging is hard to control since it is located "far" from the centre of Waraka (about $3-4 \mathrm{~km}$ along the coast). The wood of mangrove is particularly valued for building houses on stilts and little boats.

Manusela National Park is a conservation area in Central Seram. Despite being located outside the territory of Waraka, villagers all know that there is a strict control, lead by the state, to prevent all kind of harvesting, hunting and logging in this zone. Most local people understand that the park is an important refuge for many wild species such as the umbrella cockatoo (Cacatua alba), whose population is already declining around Waraka.

\section{Forest exploitation}

Control of illegal logging

First, the five villages that have common borders with Waraka on the northern part of the island immediately inform the raja of any suspect activity that could have occurred on his territory. Second, in Waraka, there is a team of four forest guards (kewang) to watch over the land. They patrol the roads and the companies' activities daily. There is also one villager, Pak Peni, who worked for 5 years for a wood company in Papua and who can detect abnormalities in "legal" logging activities. These two systems are beneficial for detecting illegal activities. The last one occurred a few months ago, where the raja confiscated the produce and the people at fault had to pay a fine.

Importance of forest resources for the community In Waraka, although not all households benefit from timber and NTFPs extraction, forests are important to everyone. Villagers collect fuelwood, benefit from hunting (wild pig, Sus scrofa, cus-cus, Phalanger maculatus, and deer, Muntiacus muntjak) are the most common species hunted. They use NTFP such as sago and enau or sugar palms, bamboo sticks and medicinal plants to eat, cook and make daily-use items such as brooms, hen houses and shrimp traps. By using NTFPs, sometimes in association with timber products, they also make furniture and build walang (huts in the center of mixed forest gardens), houses and bridges. Tables 5 and 6 present the mean household incomes provided by the exploitation of the forest.

Waraka villagers partly rely on fuelwood, especially for cooking. Ten inhabitants are specialized in logging activities. Points of logging are located either on the southern or the northern side of the main road, at the base or in the hills behind PTPN XIV's plantations (Figure 14). They sell their produce in Masohi or in Waraka, and work directly for the logging company or supply the two sawmills owned by Bapak Raja's brothers (Figure 14). They use: kayu baka, tawang (Pometia pinnata J.R. and G. Forst.), durian (Durio zibethinus), katapang (Terminalia catappa), kenari (Canarium sylveltris, Canarium oleosum), meranti (Shorea sp.) and other woods. In the near future, these sawmills will be supplied by APL, the private company. Obbie, one of the owners of the sawmill, has a logging site along the road which was opened by the private logging company (about $10 \mathrm{~km}$ from Waraka), with 12 employees. He logs wood such as: Atong laut (Parinarium glaberium), Pule (Alstonia scholaris R. Br.), Makila (Neolitsea amboinensis Merr.), Siki (Palaquium obovatum Engl.), Pulaka (Octomeles moluccana), Lenggua (Pterocarpus indicus Willd.) and all kinds of red wood (Kayu merah, Syzygium spp.). Officially, the permit that will be delivered within 2 months will allow him to exploit 50 ha and $\log$ 
up to $300 \mathrm{~m}^{3}$ per month. However, they actually use a much larger surface ("we go wherever we want" explained Obbie) and reach a production of $500 \mathrm{~m}^{3} /$ month in good conditions. Trees are about $10-25 \mathrm{~cm}$ in diameter; there is no right equipment to process larger trees. Each month, there can be up to 20 trucks of $13-15 \mathrm{~m}^{3}$ that supply Obbie's shop in Ambon. For one truck, the net benefit (when all costs are deducted) is about IDR 15 to 16 million (US\$1300-400).
APL Company's logging activities

In 2013 the Pt. Albasi Priangan Lestari or APL was granted a timber concession from the government (HPH, now also named IUPHHK-HA). This is the second time during the last decades that a company has entered Waraka territory to do logging. According to Ferry Tanaya, the director of the company, the concession covers an area of 64,000 ha in Waraka's adat territory. The concession area is

Table 5. Mean household income from forest in pilot 4 (IDR/year).

\begin{tabular}{|c|c|c|c|}
\hline \multicolumn{3}{|c|}{ Forest product } & \multirow{2}{*}{$\begin{array}{l}\text { Mean household income (IDR/year) } \\
5,975,000 \text { (US\$ 527) }\end{array}$} \\
\hline NTFPs & Cash & Mean & \\
\hline & & $\mathrm{N}$ & 4 \\
\hline & Subsistence & Mean & 1,400,000 (US\$ 123) \\
\hline & & $\mathrm{N}$ & 2 \\
\hline \multirow[t]{2}{*}{ Fuelwood } & Subsistence & Mean & $1,000,000$ (US\$ 88) \\
\hline & & $\mathrm{N}$ & 28 \\
\hline \multirow[t]{4}{*}{ Timber } & Cash & Mean & - \\
\hline & & $\mathrm{N}$ & - \\
\hline & Subsistence & Mean & $1,700,000$ (US\$ 150) \\
\hline & & $\mathrm{N}$ & 2 \\
\hline \multirow[t]{4}{*}{ Total } & Cash & Mean & $5,975,000$ (US\$ 527) \\
\hline & & $\mathrm{N}$ & 4 \\
\hline & Subsistence & Mean & $1,221,429$ (US\$ 107) \\
\hline & & $\mathrm{N}$ & 28 \\
\hline
\end{tabular}

Source: Extracted from Liswanti et al.(2013).

Table 6. Mean households income.

\begin{tabular}{lr}
\hline Forest product & Mean households income (IDR per year) \\
\hline NTFP & \\
\hline Arenga pinnata / sugar palm (fronds and fruit) & $18,300,000$ (US\$ 1,582) \\
\hline Bambusa sp. / bamboo & $1,560,000$ (US\$ 135) \\
\hline Myristica fragrans / nutmeg & 400,000 (US\$ 35) \\
\hline Sus scrofa / wild pig & $1,000,000$ (US\$ 86) \\
\hline Metroxylon sagu / sago & $5,200,000$ (US\$ 450) \\
\hline Phalanger maculatus / cus-cus & 240,000 (US\$ 21) \\
\hline Timber & 300,000 ( US\$ 26) \\
\hline Melia excelsa / kayu Bawang & $1,200,000$ ( US\$ 102) \\
\hline Terminalia catappa / kayu Ketapang & $1,000,000$ ( US\$ 86) \\
\hline Octomeles moluccana / kayu Pulaka & 900,000 ( US\$ 78) \\
\hline Anthocephalus macrophyllus / kayu Samama & IDR 30,100,000 ( US\$ 2602) \\
\hline TOTAL &
\end{tabular}


located in a limited production forest (Appendix 12 for details).

\subsubsection{Commercial plantations of PTP Nusantara XIV}

The development of commercial plantations started in the 1980s, with PNP XXVIII, a company funded by the World Bank. A total of 3000 ha of cocoa and hybrid coconut trees and 100 ha of coconut palm Nias were planted between 1983 and 1998. PNP became PTPN XIV during the 1990s. The company now uses hybrids such as coconut (Cocos nucifera) tol (kelapa dalam) $\times$ coconut Nias (kuning), and coconut Induk/ Nias (a 100 ha only). For cocoa (Theobroma cacao), the company uses plants called Sevin-M 45. It manages about 5000 ha of land out of 10,000 ha included in the land-use business rights (HGU). Today, the total area of these plantations in the administrative territory of Waraka is 2923 ha. Figure 18 shows the spatial organization of the different plantations owned by the company and Appendix 13 has details on production and work conditions. The company aims to convert the 5000 ha already planted into a rubber estate and to open new rubber plantations on the other 5000 ha that was included in the previous concession but has not been planted yet.

The following section clarifies the actors' network that takes part in the land use and land-tenure system of Waraka's adat territory.

\subsection{Actors' network and factors of changes}

The evolution of traditional and non-traditional land-use and land-tenure systems is influenced by the relationships between different actors and by the external factors of changes and pressure on natural resources that affect actors' interactions. The changes and pressure on natural resources are part of the environment of the action situation (Ostrom 1994), an environment which is also constituted by the legal framework (national laws and regulations) and decentralization institutions (Clerc 2012). The legal framework has already been discussed. Here we present the institutions, the main actors involved in the management of natural resources and the external factors that can affect actors' behaviors and interactions.

\subsubsection{Institutions}

\section{Different authorities}

There are three levels of authority acting in Waraka's adat territory: the national government, the local government, and the local customary authorities. Each village is governed by a "rich people" (orang kaya) or "king" (raja), but according to villagers of Waraka only their raja has the relevant attributes of authority to govern the land.

International organizations can influence the land use of Waraka's adat territory and its different actors. This was the case during the 1980s, when the World Bank funded the setting-up of PTPN XIV. Today, there is no organization of this kind to finance development projects or to advocate for better social and environmental practices.

\section{Conflict resolution practices}

Land conflict and disputes are managed according to adat rules, and local or national government

\section{Waraka's adat territory is used by:}

- Local communities, mainly the community of Waraka. Most food crop fields and mixed forest gardens are located on the 8100 ha of its administrative territory. They use a system of slash-and-burn cultivation and produces coconut, cocoa, nutmeg and cloves, and fruits such as bananas, rambutans and durian. They also plant sago but no rice.

- The private logging company Albisia Priangan Lestari (APL), with a concession of 64,000 ha granted by the government in the "limited production forests" of Waraka's adat territory. It currently exploits an annual area of 1700 ha. The raja of Waraka, a "close friend of APL's director" gave his oral agreement but to date no memorandum of understanding has been signed and conditions for compensation of the community remain unclear. The company employs 10 villagers from Waraka.

- The state-owned company PTP Nusantara XIV, negotiating with the government and with local communities to extend its rights of land use (HGU) that ended in December 2012. The company plans to develop its production to 10,000 ha of rubber. To date, 5000 ha have been opened by the PTPN and less than 1500 ha are dedicated to rubber production. A total of 2923 ha of Waraka's administrative territory are covered by commercial plantations of cocoa, coconut and rubber (less than 30 ha). The company employs about 30 villagers. 

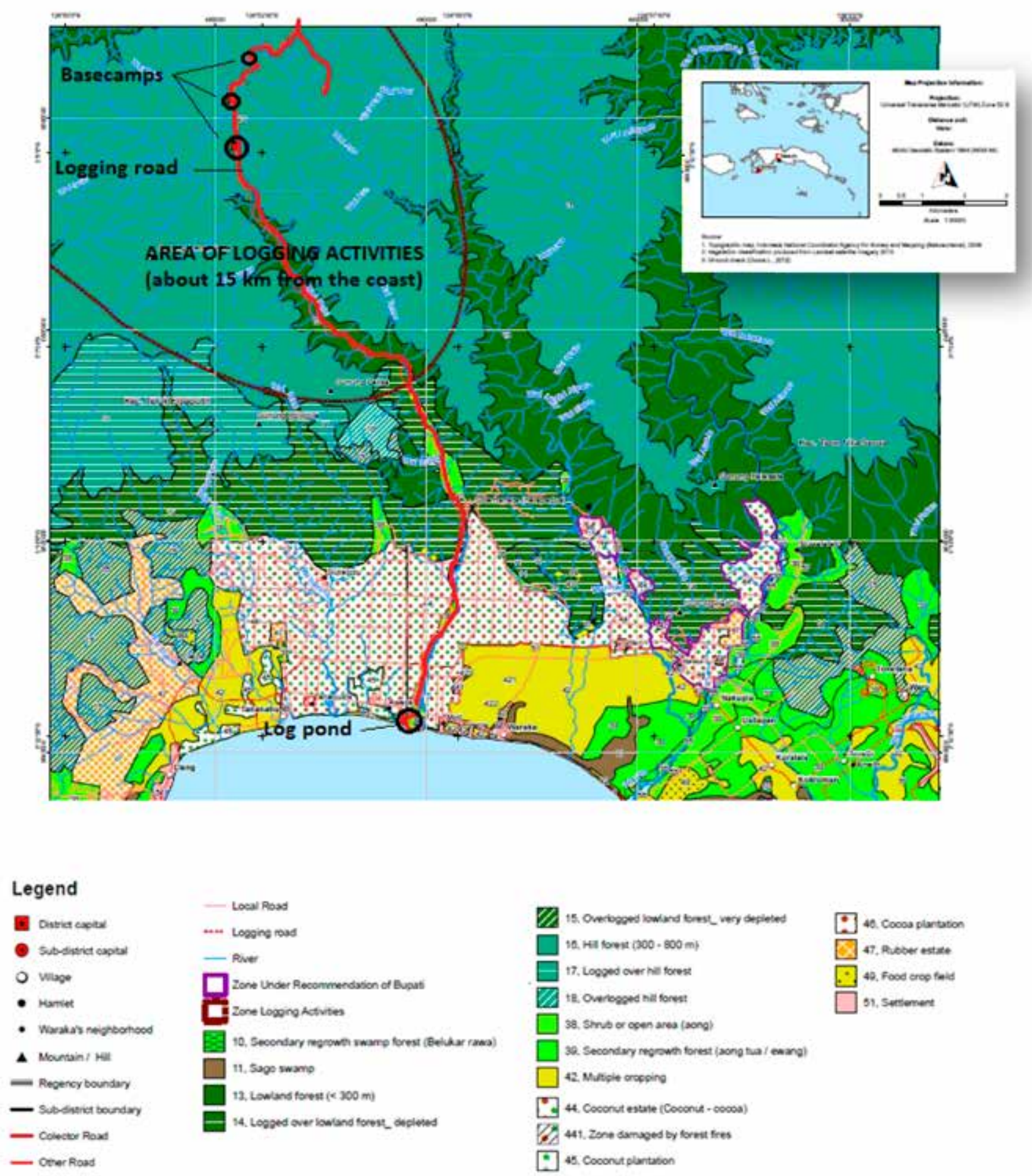

Figure 17. Land-use map: Part of Waraka's adat territory.

Source: Adapted from 2009 CoLUPSIA map, improved with groundcheck (GPS data collection) (Ducos 2013)

authorities participate, if needed. The power of the adat authority involved plays an important role in the negotiations of a conflict. Last year, for instance, the raja was invited to act as a mediator in a land-tenure dispute that occurred in the north of the island. On his adat territory, other rajas also called on him to obtain adat certificates of property so that they could prevent acts of land grabbing occurring on their territories (the east part of Waraka's adat territory is designated as a "transmigration area"). Another example of the importance of adat rules is the use by Waraka's community of sasi, which prohibits 

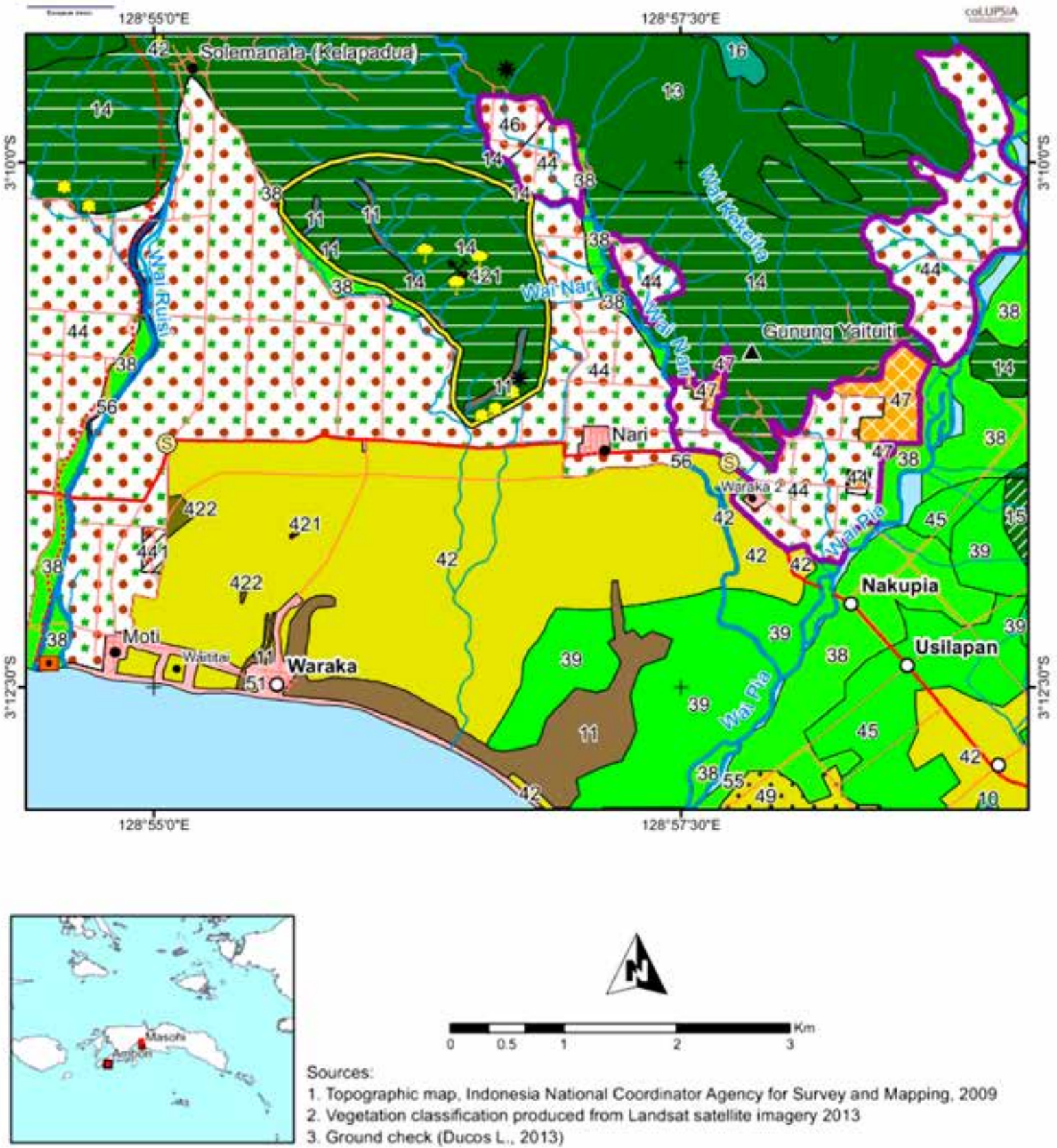

Sources:

1. Topographic map, Indonesia National Coordinator Agency for Survey and Mapping. 2009 2. Vegetation classfication produced from Landsat satelite imagery 2013

3. Ground check (Ducos L.. 2013)

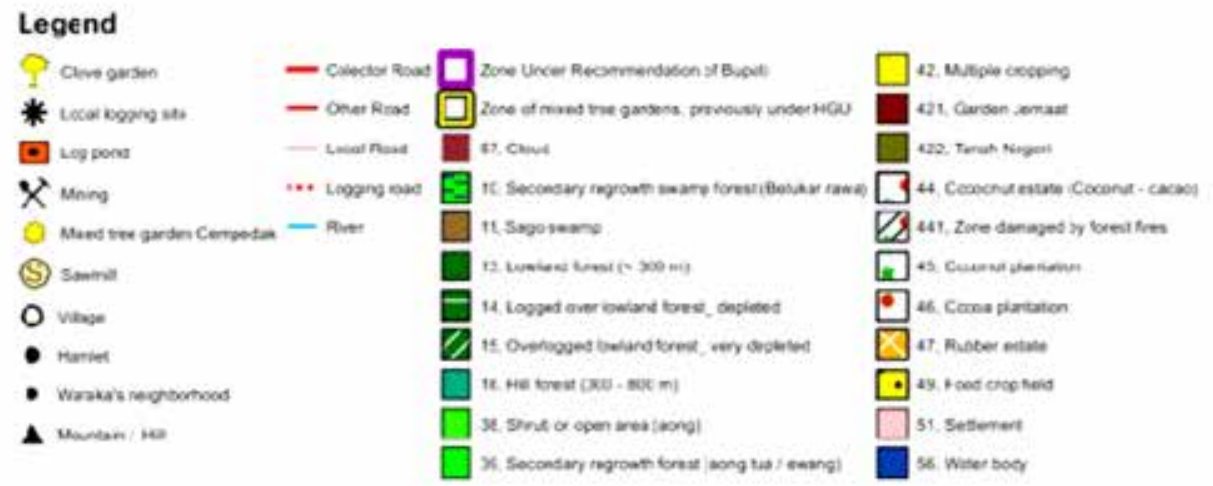

Figure 18. Map of the commercial plantations of PTPN XIV on part of Waraka's administrative territory. 
all harvesting operations in a plantation, whether it belongs to the community, an individual or a company.

Tananahu is a village in Waraka's adat territory that has administrative recognition of property rights on its land but no adat rights. In October 2013, the raja of this village took advantage of the Waraka's raja's absence and invited the governor of the region to come and recognize its adat rights of property. The raja of Waraka immediately returned to Waraka to impose his authority and prevented Tananahu from obtaining adat rights.

\subsubsection{Actors}

\section{Local communities}

Villagers share common resources and interest in improving their living conditions. Each village of Waraka's adat territory is an actor which aims to develop. However, constraints of time and organization limited this study, which focuses on the village of Waraka. Waraka's community can be characterized by its material assets such as its level of development. Most of the houses have running water and electricity. Many have televisions and other electrical devices. The village is connected by a road to the capital Masohi and the journey time is less than an hour by car. This road has existed since the 1980s and has been improved recently. According to the socioeconomic survey of Liswanti et al. (2013), $33 \%$ of 30 respondents went to senior high school, $23 \%$ of them went to junior high school and more than $50 \%$ received an income from employment. The main resource action of the village is its control of the land use of a large territory. Many farmers expressed their confidence in the future, mostly thanks to the important land resource that they manage. However, community assets (gender, social status, ethnicity, education and information) result in discordance between villagers and they can also be considered to be different actors which interact within the community. They have different degrees of control of the action arena. Two entities in particular have a higher level of control in the village: the assembly (saniri negeri) and the raja R.Y.B Lailossa.

\section{The village assembly and the raja}

In theory, the raja makes all of the decisions about the organization of the territory (social rules, sanctions, management of the land, etc.) in cooperation with his assembly, the saniri negeri. However, in practice, the raja asks the opinion of the saniri negeri for all social concerns (to solve a dispute or attribute punishment, for instance), but not for all decisions related to land use and land tenure. In the case of the logging company ALP, for instance, the raja gave the director the authorization to exploit the forest, to date, nobody, even in the assembly, knows what the benefits will be for the community. As the main representative of adat authority, the raja is a central actor in terms of the land-use and landtenure systems. His assets are his level of education (he graduated in law and in Waraka only members of his family had graduated from the university) and of information (he has relatives who work in the local government, and who travel to Ambon and to Jakarta regularly). His charming personality and charisma are also part of his assets.

\section{Commercial companies}

The logging company APL and PTPN XIV have already been presented elsewhere. They are in a relatively powerful position as they have significant local economic importance, in terms of profits generated from the exploitation of natural resources (logging activities) or because they employ a significant number of local people from the surrounding villages (cocoa company). Their investment capacities are a key asset and, in contrast to the villagers, they have wide access to knowledge and information. Their basic interest is to make profits and, from an economic perspective, they are in a favorable position: there is an increasing demand for timber and rubber, both at the national and international scales (Tempo 2013).

\section{Government}

The state has two distinct roles to play. On one hand, it is in charge of improving the preservation of the environment and the management of natural resources exploitation. On the other hand, it acts as a mediator between all stakeholders involved in activities that have an impact on the environment, stakeholders that may have divergent and sometimes contentious interests. In the case of Waraka, the state delivers rights of land use or concessions to the two commercial companies, while it also guarantees the recognition of adat rights claimed by the community. It has to balance between national and private interests of all the parties, with the incentive of avoiding conflicts.

\section{NGOs}

Local nongovernmental organizations (NGOs) have sometimes organized social programs in Waraka during the past 10 years (personal communication 
from T. Taufiqoh). However, today there is no NGO working in the village. Rainforest Alliance, an international non-profit organization works with the farmers of Sahulau who want to improve their practices and certify their production of nutmeg. As an actor, its main interest is to protect the environment and limit deforestation. They use their experience and wide access to information to implement a strategy, which aims to raise public awareness and improve commercial practices in an economic and environmental way. It seems that there is no other environmental NGO working in the region (personal comunication from Taufiqoh and Liswanti), but this information would need to be confirmed by a larger study.

\section{Center of research}

The only center of research currently acting on Waraka's adat territory is the Center for International Forestry Research (CIFOR). Its objective is to reduce forest and environment degradation, with a strategy based on participative projects of development and land-use planning. As an actor, its resources are composed of access to information and a worldwide recognition which allow the gathering of financial, technical and human supports.

\subsubsection{Factors of changes and pressure}

Waraka is located at about 40 minutes by car from Masohi, the capital city of the regency. This gives the villagers access to education and health facilities, work opportunities and, significantly, to the market. But because urban centers tend to expand, this proximity also increases pressure on natural resources. The external factors linked to this situation are developed in this chapter. They are part of the environment of our research unit, or action arena, which is the village.

\section{Proximity to Masohi}

\section{Access to market}

During the early 1980s, a road was built from the capital to the west of Seram, creating immediate connections with Waraka. Before this main access was set up, the only way for farmers to travel or to sell their fruits and vegetables to Masohi was by boat (kepiting or body). As a consequence of the road, villagers adapted their production. They started to sell less banana but more coconut and cocoa, and to grow vegetables with the use of chemicals. According to market prices fluctuations, they increase or decrease part of their production and decide to sell their stocks in Masohi or, if prices did not balance transportation costs, in Waraka. Indeed, fuel price is high and has been subjected to a recent rise of about 44\% in June 2013 (BBC Indonesia, 2013). Waraka inhabitants who have a boat sometimes prefer to transport their production by boat.

Further, Waraka villagers are familiar with market influence. During group discussions they always highlighted the importance of price fluctuations and their dependance on these. In this regard, the diversity of their production is a way of minimizing eventual loss.

\section{Education and work opportunities}

This access to Masohi immediately impacted farmers' production. It had another consequence on Waraka's inhabitants, it gave them better opportunities in terms of education and jobs in Masohi or, to other areas such as Ambon, Jakarta and Papua, and other cities. Indeed, in Waraka, many villagers already have work experience or have studied in one of these regions.

\section{Demography}

In Waraka nature resources are abundant and life easy: many people come and settle down here.

Waraka II farmer 21

(interview i.e. personal conversation 28.96.2013)

There is an average annual population growth rate of 2.80 in Maluku (Badan Pusat Statistik, 2011) and many migrants settle in the area of Waraka. The population has grown from 60 people, when it first was established on the coast, to 1721 inhabitants today (Liswanti et al. 2013). These newcomers went to Seram Island mostly because of a transmigration programme. Other incentives from the state helped people move to other islands, such as in 1999 when the island was affected by a violent interreligious conflict that started in the capital of Ambon and resulted in about 500,000 displaced persons across the province (Human Rights Watch, 2009).

Even if there are still patches of secondary forests located close to the village, on the south of the main road, these plots usually have an owner and villagers looking for land must travel further from the village. The pressure on land resources is increasing. There are also foreign, national and local investors who are looking for new lands to acquire. The next chapter briefly describes the main incentives for investment. 


\section{New investors}

Public infrastructure

The government aims to implement new infrastructure (a school and a hospital) on its territory. The first project is a STPDN (Sekolah Tinggi Ilmu Pemerintahaan Dalam), the equivalent of a faculty for future state employees. Since it would help the socioeconomic development of the area, the raja of Waraka is willing to donate 1-2 ha of land to this project. Certain conditions may be applied, such as the systematic acceptation of a few good students from the village into the school.

Second, there is also a demand for land to establish a public hospital. The raja may allocate several hectares to the school, which is seen to have potential benefits for the local population (in terms of new job opportunities).

\section{Private investments}

Regularly, private companies ask Waraka for concessions. Certain companies have already performed surveys but there are no concrete agreements in place to date. Mostly, they want to establish palm oil, rubber or coconut and cocoa plantations. The raja flatly refused to sanction the request for oil palm plantations because he thinks that oil palm needs a great amount of water and that plantations would dry up soils, which would compromise the production of sago. However he agrees to develop others kind of production (rubber, cocoa and coconut). Actually, he is currently looking for new investors to manage the 616 ha that he wants to take back from PTPN XIV, thanks to contacts that he has in other islands of Indonesia (i.e. Sumatra). There is a potential investor from Venezuela who is interested in managing the cocoa and rubber plantations but nothing is sure yet. There are also companies that look for lands as pasture for cattle. The raja refused these proposals because of "the poor conditions" for this land-use type in the north of Seram.

These public and private investments can have significant impacts on the region in terms of socioeconomic development, landscape and environment.

\section{Ambon relocation}

The head of Central Maluku District, Abdullah Tuasikal, said that "everything is ready and it is only a matter of time before the plan is realized" (Antaranews.com 2013). The idea is to move the provincial capital from Ambon to Makariki, Amahai, on Seram Island, a zone very close to Waraka. This relocation could have a huge impact on the region: It could create more work opportunities and more facilities in health and education, but seriously modify the landscape. It will also significantly increase pressure on existing natural resources.

\section{Marine resources}

Although their main activities in term of number of households are agriculture and forestry, the fishery sector remains of economical importance (Liswanti et al. 2013). Waraka inhabitants consume fish every day. Today, the marine resources are in decline.

Pak Herman, a farmer and fisherman from Waraka explains: "Since now there are lots of moves and bagan $^{3}$, it became very difficult to fish in Waraka. Sometimes we have to wait for specific periods to catch fish." In the past, villagers could fish directly from the beach at any time of the year. Today, they rely on seasons and sometimes need little boats (perahu or body) to catch fish. They proposed many reasons to explain the decrease in fish production. First, specific platforms or bagan have multiplied all over the Bay of Waraka. Second, there is an increase in pollution. A lot of trash from Waraka and from Masohi is thrown into rivers every day, which then ends up at the beach. Finally, some inhabitants are concerned about the possible impacts of climate change.

Since the 1980s, a decade marked by the opening of an access to Masohi and the introduction of stateowned and private companies, external factors of evolution and pressure impacted the traditional landuse and land-tenure systems of Waraka's territory. These factors are part of the environment that influences our action arena in Waraka's adat territory. The next section discusses tenure security through the analysis of patterns of interaction between the actors of this action arena. 


\section{Discussion}

\subsection{Land-tenure security}

In her analysis of tenure security in Kalimantan, Clerc (2012) showed that the interactions between the different actors produce several outcomes impacting the tenure security of the villagers. Environmental constraints and opportunities (linked to the biophysical environment, but also the institutional environment and the attributes of the community or village) and the attributes of each actor (resource action or asset, interest, strategy and action) combine to create several outcomes or patterns of interaction indicating a certain degree of tenure security.

In the present situation, I identified four patterns of interactions as indicators of tenure security:

- The degree of cooperation and conflict between the different actors;

- The enforcement and compliance to the rules allocating rights;

- The ability of the right holder to maintain and defend his rights;

- The distribution of rights that are exercised in practice.

The identification of these patterns of interaction in Waraka is developed in the following chapters.

\subsubsection{Relations between the village of Waraka and other actors}

\section{Conflicts with the PTPN XIV}

According to the staff of PTPN XIV and compared to cocoa and coconut plantations, rubber plantations suffer less from pests and diseases and it is harder to steal the produce. The company's directors agree and stated that: "there are three pests here: the cocoa pest, the animals such as cows and wild pigs, and people." Local people say that PTPN XIV is on their lands, and that despite their promises they have not offered any compensation to the community. This may be why farmers often harvest cocoa and coconut from the company's plantations. Furthermore, PTPN XIV has not renewed its permit yet. Therefore, local people know that the company cannot appeal to the law if they catch anyone harvesting their produce. As a consequence, farmers feel free to "visit" PTPN XIV's plantations.

\section{A source of conflict?}

The company plans to replace its 5000 ha of rubber plantations and to extend it by an additional area of 5000 ha which is not yet planted but which was included in the previous concession. Located on steep slopes, these 5000 ha are still free of plantations because cocoa or coconut production is too difficult to establish there, but for rubber it is possible to make terraces and use new technonologies and new clones. Some local farmers have claims on that area where they often plant clove trees.

\section{Additional land requierement by the regent} The zone of 616 ha that was under the regent's (bupatis) authority but which never entered the HGU could become a source of conflict. Today, 450 ha of this zone are planted (mostly old coconut and cocoa plantations; less than 20 ha are recent rubber plantations). It is possible that the company doesn't respect the sasi imposed by the raja after he witnessed that the company was not complying with any of its promises. Maluku people are known to be hot-tempered and reprisals could happen fast if the company violated the rule of sasi. They could for instance, burn office buildings, as happenned in another location where community burnt down the rubber factory during the religious conflict of 1999-2004.

In summary, even if it is conflictual, the community is still in dialogue with PTPN XIV and has agreed to renew the contract of land-use rights. The two important issues are: the ability of the raja to claim and defend community rights and the significant respect accorded to the adat and its system of sasi. By ensuring an open discussion and searching for a compromise, the raja is trying to avoid the departure of the company and the loss of hundreds of jobs, which will also affect other villages.

\section{Relations with APL}

In various interviews, the raja explained that he was "very close to the director of APL" and that he trusted him. Whether the community will benefit

4 The sasi is located on the area that was under the regent's recommendation, between the rivers Nari and Pia: nobody is allowed to harvest the plantations in this zone. See Figure 18 (map) (purple delimitation of a "zone under the recommendation of bupati"). 


\section{What would be the impact of transforming the 10,000 ha concession into rubber plantations?}

In rubber plantations, the company needs approximately one person per day per hectare, with a rotation of three days (or $3 \mathrm{ha}$ ), which means that they can hire 33 people for $100 \mathrm{ha}$. According to the director's assistant, in cocoa plantations they need three persons per hectare. Hence in rubber plantations they need almost ten times fewer employees than in cocoa plantations. Nevertheless, the company argues that the total number of employees will increase as rubber plantations they will need more capacitated villagers, with long-term contracts: they will work throughout the year and not only during the times of peak production. This may reduce the gap between the two numbers of employees needed. Finally, if they double their area of production, they will hire even more people. The problem remains the features of the contract that they apply to their employees: The majority is paied based on their production per kilo of harvested product (system borongan). All villagers would prefer to be payed on a daily basis rather than per kilo. Daily-contracted employees are paied $3000 \mathrm{rp} / \mathrm{kg}$ of lump. Hence they have to harvest $16.5 \mathrm{~kg}$ of lump every day to reach the minimum salary of IDR 51,000 per day, which means about 36-40 I of latex (the latex reduces by about $65 \%$ into lump). In Eldeuw site, where trees are already about 30 years old, an employee needs to harvest the latex of around 250 to 300 trees to reach the amount of liquid desired. In summary, the total number of employees is likely to decrease and some of Waraka inhabitants will not work at the company (to date they have not shown interest in working in rubber plantations).

from this concession for logging activities remains unclear. Everything depends on the raja. If he eventually receives the right compensation and redistributes it to the village in a transparent way, there will be no problems. However, if he does not get proper retribution, he will not be able to protest as no memorandum of understanding $(\mathrm{MoU})$ has been signed to date.

A proper retribution would have to take into account all values that can be attributed to a land: Its economical value, which corresponds to the maximum profit you can gain from it, and its cultural and environmental values (Liswanti et al. 2013). However, to date, with the exception of carbon stock, there are no commonly accepted criteria which could be used to define these non-economic terms. The idea for the community is mainly to keep these aspects in mind when negotiating compensation for the use of its land. In the case of Waraka, the raja has a weak sustainability approach: the forest is viewed as an economic resource, which can be replaced by other kinds of natural economic resources such as industrial plantations of Albizia spp. There is no tax related to the area of land exploited by the company, or to eventual impacts on watersheds, soils and biodiversity. However, as Pak Henki explains: "Now there are many logging activities, and great changes occurred. Before we could get a lot of rattan and huge trees such as lenggua, but that's not the case anymore." Another member of a focus-group discussion, Ibu Nona, said that: "Before in Waraka there were many birds, wild pigs and deer. But today, since the forest is damaged, animals are hard to find." Despite these observations, there has been no study to date to determine the impact of the non-planned logging activities on the environment.

\section{Relations of conflict and cooperation inside the village}

Intergenerational conflict: Is the young generation not interested in farming anymore?

It seems that the young generation is losing interest in mixed tree gardens management. Some of the young prefer other kinds of jobs such as working for service companies or in state administrative jobs. Many villagers expressed their worries about the young who did not seem to be interested in farming anymore. If the population keeps growing and there are fewer new farmers to take over, the quality of production will decrease and there will be globally less food and fewer cash crops to harvest. This situation is already happening with regard to clove production and it could happen with nutmeg production (progressive abandoning and decrease in production). Villagers' dependency on other sources of food from markets or cities such as Masohi, could increase their vulnerability and lead to tensions between farmers and non-farmers, and between the young generation and the older. Such an development would cause the population to rely more on other sources of financial income. As they would need more employment, their dependency on private or public companies would increase and the community will have even less power during negotiations. 


\section{Religion}

In Waraka, about $80 \%$ of the population is Christian, with a majority of Protestants, and about $20 \%$ are Muslim. This distribution is different from the major part of Seram, which has a majority of Muslim people. According to the priests, in recent times there are fewer people attending church services. Religious activities form the pattern of villagers' lives and are part of their land-use management. For how long will this system be sustainable? If the number of participants in Christian ceremonies or in jemaat gardens' organization decreases, these traditions might disappear or, at least, change. This could lead to abandonment of part of the land (jemaat).

However one must keep in mind that fewer than 10 years ago, the struggle between Muslims and Christians led to the relocation of thousands of people. In Waraka there is a relative harmony between the two religious groups, but a conflict could disturb this friendly but fragile relationship.

\section{The community and the raja}

Every month there is a village meeting (rapat negeri). It is an occasion for the upu latu to deliver information and less of an opportunity for citizens to ask for what they want. Villagers describe the raja as "easily offended" and says that "he does not receive critics that call into question his decisions." The number of participants in these meetings is decreasing: the population is not taking part in the decision-making process concerning land-use rights. Villagers demand new attributions of land with adat certificates of property. However, since 2009, the raja has stopped this procedure to prevent the land from being sold. There is a clear lack of trust - claimed by both sides - between the raja and members of the community.

\subsubsection{Rules and promises}

The logging company APL promised to pay royalties as compensation. IDR 17,000 per $\mathrm{m}^{3}$ was first offered by the company to the raja of Waraka but the governor of Masohi recommended a minimal amount of IDR 25,000 per $\mathrm{m}^{3}$. There is no written $\mathrm{MoU}$ yet. The raja plans to use the money to develop the village infrastructure (office, bridges, school, etc.). The company also promised new job opportunities, but, to date, they have offered only a few jobs in bark removal and in carrying out inventories in remote areas. Most of the villagers in Waraka refuse to work for the company due to the tough working conditions, requirement to live in a camp and the low salary. They do not value a temporary job as much as farming activities.

Only satellite imagery can show if the company is staying inside the limits of its concession. There are four forest guards from Waraka who check the logging activities, but it is not enough to survey an area of 1700 ha. The MoF of Masohi also came to oversee the site, but the vice-governor of Central Moluccas said that this institution was corrupt, which was impossible to verify.

For the 30-year period of their first concession, PTPN XIV has been promising the Waraka community technical and financial support for infrastructure (i.e. improvement of roads, construction of offices) and education. Villagers explained that the company has never complied with its promises. For the extension of the HGU, the community and the raja asked for a written agreement in which the PTPN XIV would commit to take charge of children's education in Waraka up to the grade of master's degree and to give long-term contracts to all its current employees from the village. Most employees from Waraka work under a daily contract, with a salary based on their production (golongan). The local company director said that he needs the agreement of his superior located in Sulawesi Island in order to answer the community's claims, which has not happened yet. There is no certainty about the progress of current negotiations as the extension is an ongoing process.

\subsubsection{Changes in the distribution of land rights}

\section{Rubber plantations of the PTPN XIV}

To develop its rubber plantations, PTPN XIV plans to open an additional area of 5000 ha which was included in the previous 10,000 ha concession of land-use rights (HGU) but was never actually opened. Part of this land overlaps the area of mixed forest gardens, which belongs to Waraka's community. If the raja does not exclude this zone from the new HGU, the company will be allowed to settle in the area and villagers' mixed tree gardens could be replaced by rubber plantations. In this area, which is considered by the company as a "forest estate and not the property of the community", farmers do not have property certificates or any other kind of tool to stand up to land transformation. 

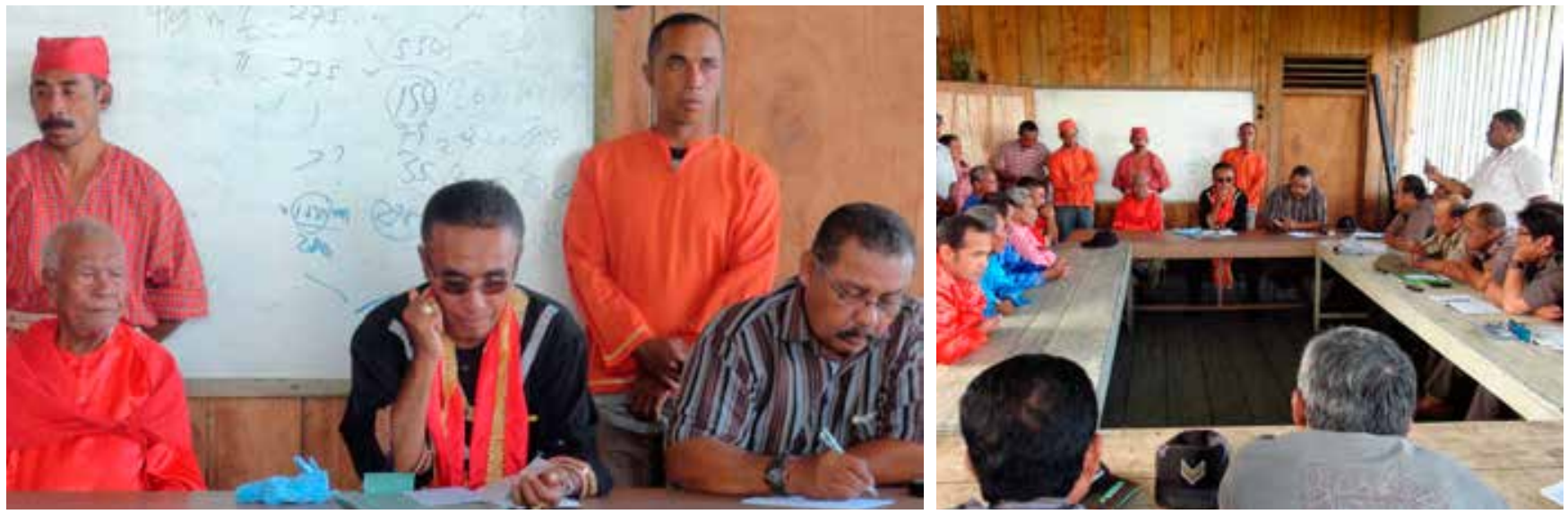

Figure 19. Negotiations between the community of Waraka and PTPN XIV. Left: The raja sits between the head of adat and the company's director. Right: Overview of the meeting, with members of the community in traditional clothes and members of the company in front.

\section{Additional land requierement by the regent}

The situation concerning the zone of 616 ha that was under the regent's authority but which never entered the HGU is unclear. If it is not included in the new HGU and with no renewal of the regent's recommendation this year, the community of Waraka will be able to use these lands as part of its administrative territory. It would become the common property of the village and the raja would implement a system of benefit-sharing to harvest the plantations. However, the company argues that these lands are state-owned and they may try to keep on growing rubber on it (they recently established new rubber nurseries and plantations there).

\section{Concession of land-use rights for logging activities}

It appears that villagers are not familiar with APL concessions. However, members of the village assembly and forest guards maintain that the company is allowed to exploit the land that they have rented for the past 5 years (or 10 years, according to the company). Moreover, the APL director only carried out activities in areas which do not overlap with other communities' territory. Indeed, the activities of APL are located $15 \mathrm{~km}$ away from the village, where villagers do not farm and where questions of community rights are not at stake.

\subsubsection{Ability to defend one's rights and perceived tenure security}

\section{The ability of the community and the raja to defend their rights}

In Waraka's adat territory, customary land rights are undocumented. Social status, charisma, information and knowledge are the key factors that enable a rightholder to defend their land-tenure rights. Although Waraka villagers intend to get new certificates to protect their land from land grabbing, they can't protest against the raja who refuses to issue certificates in order to prevent land selling. In fact, they feel powerless in front of the raja (informal conversation with farmers).

The recognition of the MoU features with the logging company relies on the ability of the raja to claim his rights and on the degree of trust he has in the director. This ability can be balanced by the difference of economic power between the two actors. There is a risk of corruption from the company to the raja or to forest guards in charge of the surveillance of the logging site. One of the saniri negeri's members said that F. Tanaya gave him IDR 500,000 (US\$ 44) and gave the raja IDR 20 million (US\$1750).

However, the raja affirms that he has never received money. If he is corrupt, the raja would not be able to defend his community's rights properly. Villagers, left without clear information, are not able to stand up for themselves. In the case of PTPN XIV, the raja negotiates and takes decisions by himself, sometimes with the assembly's advice. However, the raja sometimes involves the community to increase his power during negotiations.

\section{Perceived tenure security}

When the raja gathered the certificates of property, most farmers felt that they lost control over their land. However, they did not consider this loss as a threat because this came from the raja and not from an outsider. Moreover, they do not feel concerned by land-tenure issue for forests logged by APL because 
they are located $15 \mathrm{~km}$ from the village. Their worries mainly focus on what is going to happen with PTPN XIV, but more in terms of contract features (work and salary conditions) than in terms of land tenure. They do not have information about the company's plan to develop rubber plantations and about the situation of the 616 ha that were under regent's recommendation. As an illustration, the forest guards who knew about the recent plantation of rubber in the 616 ha area did not even alert the raja.

$* * * * *$

The situation in Waraka is unique in Indonesia. The traditional system of governance influences the four patterns of interaction: distribution of rights, degree of cooperation and conflict, enforcement and compliance to the rules and ability of a right holder to maintain and defend his rights. A distinction must made between relationships the companies have with the community and with the raja. Land-tenure security in Waraka largely relies on the raja's ability to defend community rights and on his relationship with both companies. These factors are even more important in 2013 as logging activities have just started and PTPN XIV is trying to renew its landuse rights concession - the future development of land-tenure security depends on oral agreements. The absence of written documents adds uncertainty to land-tenure security in a context that is already unclear in terms of the law. The results of these negotiations will influence the impacts of companies' activities (in terms of their level and nature) on the socioeconomic development of the village and on the environment. The following section aims to discuss evolving perspectives.

\subsection{How to reconcile socioeconomic development and environmental preservation}

\subsubsection{Governmental support to community development programs}

\section{A need for external support?}

Many development initiatives and projects supported by the government or NGOs have failed in Waraka. For instance, an incentive to develop a new commercial plantation was given to local people through the allocation of 600 plants of rubber trees per person and per hectare. Today only one of the villagers still manages part of a rubber plot. The main reason for this failure is that, in addition to the requirement for early harvesting (which must start at 5 or 6 a.m.) and regular care, Waraka's inhabitants do not have the right skills to manage rubber plantations. Despite their experience with rubber, the community seems to be very interested in planting other kinds of trees, especially fruit tree species which can generate a cash income. They are asking for seedlings of rambutan aceh (better than rambutan madu), duku and langsa, durian and a wood tree, Albizia falcata Backer or salawaku in Wemale. With adequate financial and technical support, the community could manage a plantation of this species, which could be used for pulp and paper commercial production. CIFOR, through CoLUPSIA, has started to assess the feasability of this project. As a first step, CoLUPSIA's members looked for areas where abundant natural regeneration occured in order to find sources of seedlings. No zone of natural regeneration, which could provide a sufficient number of plants, has been found to date. Moreover, finding an adequate location for an Albizia plantation is difficult. The support of another party could be useful. The MoF recently developed a new program supporting the installation of a community nursery program (Kebun Bibit Rakyat; KBR). It could be used in Waraka to produce seedlings of Albizia, fruit and other wood species and possible rubber trees. As the cocoa company plans to extend its rubber tree plantations, some villagers will be trained for that purpose. They could use these new skills to set up private productive areas of rubber. The use of performance-based payments may give the villagers motivation to achieve the target number of seedlings.

Hence, such communitary-based project of reforestation could promote socioeconomic development and environmental preservation. In order to avoid the repetition of previous failures, prerequisites such as costs, land and material availability and, last but not least, villagers' motivation to join, have to be assessed before implementing the program. Such an initiative could work through the implementation of a carbon credit system such as REDD+.

\subsubsection{Feasibility of a REDD+ initiative in Waraka}

In Waraka, the market for PES such as watershed protection or ecotourism does not yet exist. The only environmental service which is likely to find buyers and be enhanced, despite the other difficulties described above, is the sequestration of carbon. 


\section{Payment for ecosystem services}

A component of the CoLUPSIA project is to explore the potential options for establishing PES projects within the pilot sites identified in Seram and Kalimantan. The main difficulties for the establishment of a PES system in Waraka were identified by Liswanti et al. (2013):

- Traditional land boundaries, although recognized by other villages are not legally recognized by district, provincal or national governments.

- There is a risk of encroachment by neighboring communities because of the potential distance between location of the project site and the village.

- A buyer must be identified.

- Technical and administrative capacity is currently limited.

It seems that the best option for PES concerns carbon credits. In September 2009, the president of Indonesia, Susilo Bambang Yudhoyono, announced the target of a $26 \%$ reduction in national emissions by 2020 (Ministry of Forestry 2010). He stated that $14 \%$ of all emissions reduction should be achieved in the forestry sector and particularly through REDD+. To receive REDD+ payments, the clarification of forest tenure and the recognition of local customary rights are considered a key strategy (Sikor 2010; Larson 2011; White 2011). In Waraka, except for the lands used by PTPN XIV, administrative boundaries are clear and well-defined. Hence, if there is a serious initial assessment of the situation, the implementation of a REDD+ program to support the implentation of a nursery project, for instance, could be considered. Moreover, it would require the presence of institutions such as NGOs or the MoF to help the community meet such a program's requirements (clarification of the right steps to follow, measure of the carbon stock, etc.). Additionally, concerning local logging business, it would be interesting to see if the raja's brother, who is exploiting between 50 and 100 ha in unsustainable conditions, would agree to follow a REDD+ program. It could be done through a shift to new responsibilities as manager of the nursery program and, more consistenly, of the Albizia plantation that could easily supply his sawmill and his shop in Ambon. We could also imagine a compensation for opportunity costs if he would accept to stop or improve his exploitation. However, his current activity is highly lucrative and the opportunity costs may be too high to be compensated by REDD+ funds. The same problem occurs in the case of the APL exploitation. It is conducting logging activities on thousands of hectares and the benefits are far too important to be compensated through a REDD+ program. Thus, the question remains: How do we reduce the impact of wood exploitation in Waraka's forests territory?

\subsubsection{Solutions for the prevention of forest degradation}

There are at least two main solutions that could be used on Waraka's territory. The first is the revision of the classification of the forest status in order to match the actual situation. The second is the implementation of reduced impact logging practices.

\section{The right classification}

As shown by the map SK 415 (Figure 11), the forest of Waraka's territory are officially classified as 'limited production forest', including two patches of protected forest. However, in order to establish this classification, the government used recognition scale data (scale 1:250,000). By using the same official criteria of precipitation, slope and soil erodibility but with more accurate topographical data $(1: 50,000)$, CoLUPSIA has proposed a new zonation that will have a dramatic impact on the legality of existing logging activities. Figure 20a shows that the logging concession $(\mathrm{HPH})$ has been mainly established on areas of very steep slopes. Using 1:50,000 scale maps, CoLUPSIA researchers gave a more accurate map of Seram Island's land. It is clear that the whole area located north of Waraka should be designated as watershed protection forest (butan lindung). Hence, if the state followed its own system of land category zonation, all logging activities would be prohibited in the territory of Waraka. This decision would be a radical means of limiting forest degradation in this zone. Meanwhile, the government may have to consider changing the management rules concerning the land status of hutan lindung, in order to authorize local people to harvest timber products for private needs - a practice which is forbidden in the regulation. Moreover, when a company use part of the 'forest estate', it has to pay high taxes, which largely benefits the government. Hence, if the state's financial interests are higher than its environmental preoccupations, it may be harder for it to accept these new maps. CoLUPSIA will support the legal process for the acceptance of this revision of the land allocation map for central Moluccas.

\section{Reduced impact logging practices}

The Tropical Forest Foundation (2009) defines reduced-impact logging (RIL) as a set of management practices that presents a more sustainable solution 


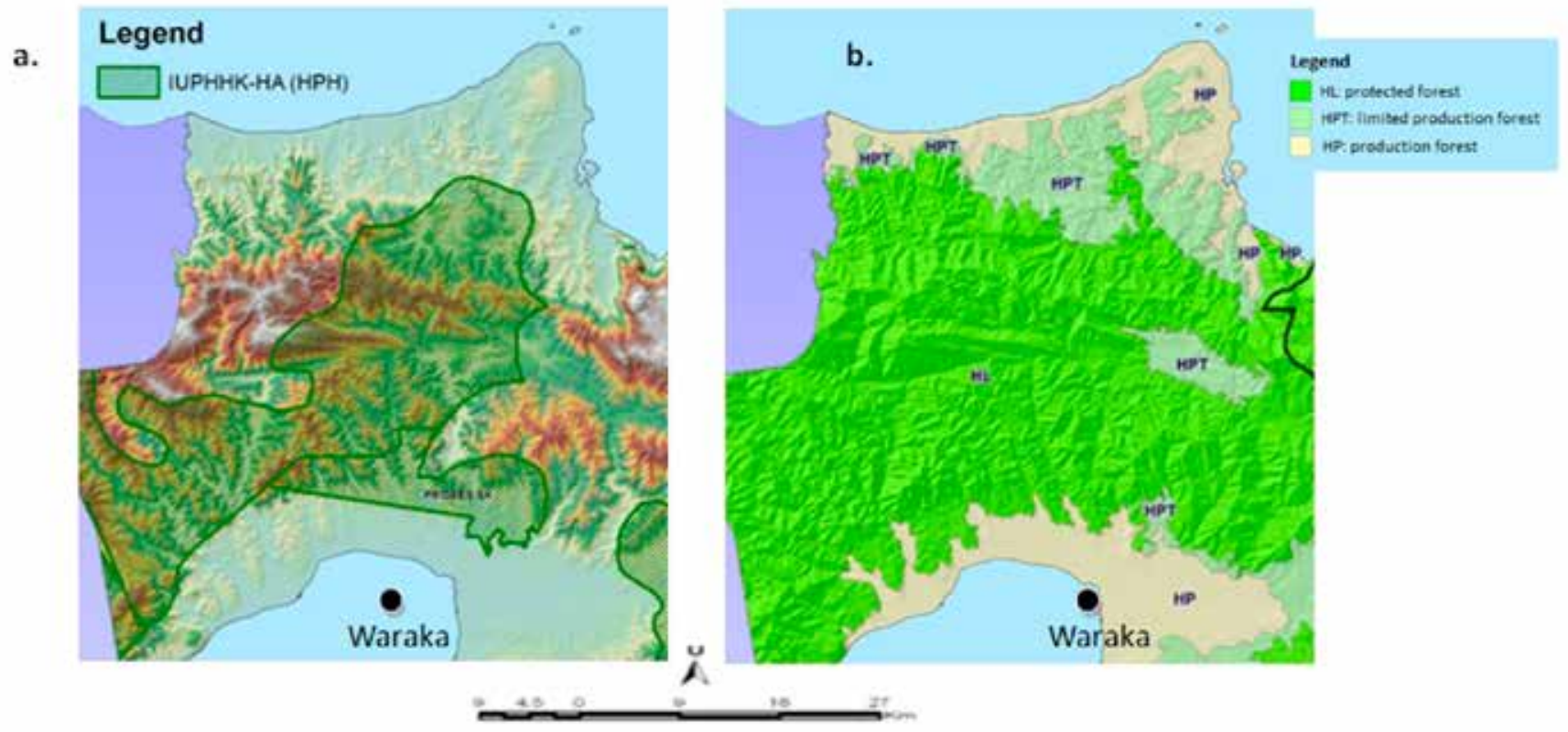

Figure 20. (a) Logging concession (HPH) overlayed on the Digital Elevation Model based on CoLUPSIA data. (b) Zonation for land allocation using 1:50,000 scale topographic maps by the CoLUPSIA project.

for timber harvesting. Basically, RIL consists of a combination of pre-exploitation, exploitation and post-exploitation activities which "reduce disturbances to soil and residual vegetation by at least $50 \%$ in comparison with conventional logging operations, limit overall direct impacts to the forest to $<25 \%$, conserve wildlife and other forest resources, diminish direct logging costs by at least $15 \%$ and protect the long-term integrity and value of the permanent forest estate" (Sist et al. 1998). ). In Brazil, Vidal (2011) showed that RIL practices have reduced the cost of US $\$ 1.84$ per $\mathrm{m}^{3}$, or in other words by $19 \%$ compared to conventional logging. Thus, the application of RIL practices is a way of minimizing damage to the environment caused by logging activities, while reducing exploitation costs. If it was applied by logging companies, all stakeholders of the related region could benefit from this system. The problem is that it is difficult to get logging companies interested in these kind of practices. Generally, they are not aware of the financial benefits made thanks to RIL practices and they do not choose to invest in pre-exploitation practices. In order to inform, raise awareness and train the actors in logging activities (APL company, communities), the government could support the creation of a regional or national center specialized in training these actors in RIL practices, as was done in Brazil by The Tropical Forest Institute (Instituto Floresta Tropical). It would also be important to adapt some of these RIL practices to the specific conditions of hutan lindung, areas of watershed and soil protection.
Training is not always enough to reduce the impact of logging activities. For example, Obbie, the raja's brother, does not have the right equipment to exploit the forest. It leads to the logging of trees with a diameter less than $45 \mathrm{~cm}$ (unsustainable conditions). In this case, a technical or financial support from the village, the government or other institutions such as NGOs could enable the purchase of proper exploitation equipment and therefore reduce the impact of the activity on the forest. Eventually, as this kind of project prevents forest degradation, it could enter a REDD+ program.

\subsubsection{Certification schemes}

Since the quality of the cocoa production in Waraka is quite low, it is unlikely that efforts will be made through a certification scheme. Some activities have already taken place in the region for nutmeg. In Sahulau, for instance, the Ministry of Agriculture together with other institutes organized a workshop on the production of this cash crop. About 20 villagers from Waraka attended the meeting. As of today, in Tananahu, a few farmers have already started to work with Rainforest Alliance to obtain their certification on nutmeg production. This idea of certification could be a future objective for some Waraka farmers who would like to develop their production of nutmeg. It could increase their benefits if their production reached the required social and environmental standards. Clove production could also be a target for certification. 


\subsection{Practical difficulties and limitations of the study}

My stay of 2.5 months in the same community gave me advantages but presented many inconveniences. As there was nobody with the required experience in the village to help me set up techniques which I had never done before (i.e. focus-group discussions, participatory mapping, etc.), it gave me time to adapt and improve my methodology. I already spoke Bahasa Indonesia but that was not enough: the language remained a limit to the understanding of the complex land-tenure system in Waraka's territory.

I was able to observe and understand the evolution of the situations with both companies. In this sense, the proximity I had with the community helped (directors received me for longer after the raja called them), but this proximity could have introduced a bias in their answers during the interviews. The logging company was also afraid of what I could see on their production site because "as a forest engineer, [I] know" (informal interview with the technical supervisor of the operations). Furthermore, as the raja is a central actor in the land-tenure system of Waraka, lots of information depended on his transparency and it was not always possible to triangulate what he was telling me (especially concerning his agreement with APL).

Difficulties also occurred when trying to obtain official documentation in order to conduct the research in Seram. The exact reason was never given, but the government first refused to provide me with a visa. Once I had the visa, they did not renew the other authorization I needed. I did not get the opportunity to meet with the local ministries of forestry and agriculture. A more complete study of land-tenure security could be achieved by interviewing more external actors. Actually, in order to do a proper analysis of land-tenure security in Waraka's adat territory, I would have needed 6 months. I had a number of objectives to fulfill (identification of traditional land use; understanding of contracts' features that the community established with the companies; cartography of the area) and could not analyze the situation in as much depth as I would have wished. 


\section{Conclusion}

Land-use and land-tenure systems in Waraka evolve in a rapidly changing environment. Traditional land use has slightly adapted during the last decades, but it seems that greater changes are coming. Some farmers highlighted the importance of their agroforestry systems as a regular and stable source of food and financial income that largely prevails over the potential benefits of wage labor. Part of the population is looking for new sources of employment and trying to sell its land to invest in children's marriage and education. The interest of the young generation in agriculture is declining and the relations between Christians and Muslims are good, but fragile. In this context, the raja creates another source of tension by centralizing all the powers and controlling the socioeconomic development of the community. Without consulting the villagers, he gave his agreement to companies to develop commercial activities on Waraka's adat territory. This behavior creates a confused situation that justifies the study of Waraka's land-use and land-tenure system. Indeed, in Indonesia, the establishment of private logging companies is often contentious (Yasmi 2007) but this is not the case in Waraka, where the company's director is the raja's "friend". As a matter of fact, this system based on the raja's ability to negotiate cannot be used as a model for other regions. In Waraka, there is no conflict but there is no guarantee that the development of logging activities will benefit the community, and it seems that environmental degradation there is already significant. However, study of the activities of the cocoa state-owned company shows that the impact on the environment may not be as disastrous as one might think, but that the relations with the local communities are contentious.

The use of the institutional framework and analysis methodology has been particularly relevant to understand the multivariable dynamics of Waraka's land-tenure system. Additional long-term research would be useful for a deeper analysis of the situation. The relations with both companies are evolving fast and they will have even greater impact on society and the environment when written documents which define the features of their agreements with the community are drawn up. 


\section{References}

Akiefnawati R, Villamor GB, Zulfikar F, Budisetiawan I, Mulyoutam, E, Ayat A and van Noordwijk M. 2010. Stewardship agreement to reduce emissions from deforestation and degradation (REDD): Case study from Lubuk Beringin's Hutan Desa, Jambi Province, Sumatra, Indonesia. International Forestry Review 12(4):349-60.

Alexander ER. 1991. Approaches to Planning: Introducing Current Planning Theories, Concepts, and Issues. Philadelphia, PA: Gordon and Breach Science Publishers.

Antaranews. 2013. Overcrowded Ambon city needs relocation. Accessed 16 September 2013. http://www.antaranews.com/en/news/90683/ overcrowded-ambon-city-needs-relocation

Asie360. 2013. Convertisseur de devises. Accessed 31 October 2013. http://www.asie360. $\mathrm{com} /$ convertisseur/devises/ liste-des-valeursmonetaires-des-pays-asiatiques.html

Badan Pusat Statistik. 2010. Hasil Sensus penduduk 2010, Agregat data per kecamatan. Accessed 10 October 2013. http://sp2010.bps.go.id/files/ ebook/8103.pdf

Badan Pusat Statistik. 2011. Statistics Indonesia. Accessed 3 September 2013. http:// www.bps.go.id/eng/tab_sub/view. php?kat $=1 \&$ tabel $=1 \&$ daftar $=1 \&$ id subyek $=12 \&$ notab $=2$

BBC Indonesia. 2013. Harga BBM naik di tengah protes masyarakat. Accessed 3 September 2013. http://www.bbc.co.uk/indonesia/laporan khusus/laporan_bbm.shtml

Clerc J. 2012. Unpacking tenure security: Development of a conceptual framework and application to the case of oil palm expansion on customary land in Kapuas Hulu district, West Kalimantan, Indonesia. Working Paper No. 102. Bogor, Indonesia: CIFOR.

Colchester M. 2006. Promised land: palm oil and land acquisition in Indonesia: Implications for local communities and indigenous peoples. England; Bogor, West Java: Forest Peoples' Programme and Sawit Watch, HuMA, World Agroforestry Centre (ICRAF).

Constitutional Court Decision No. 45/PUUIX/2011 (MK45), 2012. Constitutional court decision on indonesia's forest zone could lay groundwork for sustainable low emissions development. National Constitution Press Release, Jakarta, Indonesia.

Djogo T and Syaf R. 2003. Decentralization without accountability: Power and authority over local forest governance in Indonesia. Bogor, Indonesia: CIFOR. Accessed 16 September 2013. http:// www.cifor.cgiar.org/acm/download/pub/DjogoEWC.pdf

Durey L. 2014. Land-use planning in the Moluccas: What of customary tenure security? Working Paper No. 143. Bogor, Indonesia: CIFOR.

Edwards ID, Macdonald AA and Proctor J. 1993. Natural History of Seram, Maluku, Indonesia. Operation Raleigh, Raleigh International, Andover, Hampshire, England: Intercept.

Ellen R. 1997. The human consequences of deforestation in the Moluccas. In Les peuples des forêts tropicales. Systèmes traditionnels et développement rural en Afrique équatoriale, grande Amazonie et Asie du sud-est. (eds) DV Joiris and D de Laveleye. Special issue of Civilisations 44(1-2):176-93.

Ellen 1985. Patterns of indigenous timber extraction from Moluccan rain forest fringes. Journal of Biogeography 12, 559-587.

Export Entreprise SA. 2013. Législation du travail, Indonésie. Accessed 31 October 2013. http:// lemoci.com/Indonesie/41-Legislation-dutravail.htm

[FAO] Food and Agriculture Organizaton of the United Nations. 2011. Situation des forêts $d u$ monde 2011. Rome, Italy: FAO.

Fuys A, Mwangi E and Dohrn S. 2008. Securing common property regimes in a globalizing world. Synthesis of 41 case studies on common property regimes from Asia, Africa, Europe and Latin America. CGIAR System Wide Program on Collective Action and Property Rights, Rome: International Land Coalition. Accessed 19/09/2013 http://dlc.dlib.indiana.edu/dlc/ bitstream/handle/10535/5363/ILC_Securing Common_Property_Regimes_E.pdf?sequence $=1$

Hardin G. 1968. The tragedy of the commons. Science 162(3859):1243-48.

Harwell EE. 2000. The un-natural history of culture; ethnicity, tradition and territorial conflicts in West Kalimantan, Indonesia, 1800-1997. [Ph.D. thesis] New Haven, CT: Yale University. 
Human Rights Watch. 2009. Religious conflict 1999-2004, Maluku. Accessed 3 September 2013. http://www.hrw.org/reports/1999/ambon/ amron-01.htm

Kaya M, Kammesheidt L and Weidelt HJ. 2002. The forest garden system of Saparua Island, Central Maluku, Indonesia, and its role in maintaining tree species diversity. Agroforestry Systems 54:225-34.

Kumar BM and Nair PKR. 2004. The enigma of tropical homegardens. Agroforestry Systems 61:135-52.

Larson A. 2011. Forest tenure reform in the age of climate change: Lessons for REDD+. Global Environmental Change 21(2):540-49.

Leinbach T. 1989. The transmigration programme in Indonesian national development strategy: Current status and future requirements. Habitat International 13(3):81-93. Accessed 22 August 2013. http://www.sciencedirect.com/science/ article/pii/0197397589900234

Liswanti N, Fripp E, Silaya T, Tjoa M and Y Laumonier. 2013. Socio-economic considerations for land use planning: the case of Seram, Central Maluku. Working Paper 109. Bogor, Indonesia: CIFOR.

Ministry of Forestry. 2010. Indonesia Second National Communication under the United Nations Framework Convention on Climate Change (UNFCCC). Accessed 26 August 2013. http:// unfccc. int/files/national_reports/non-annex_i_ natcom/submitted_natcom/application/pdf/ indonesia_snc.pdf

Monk K, De Fretes Y and Reksodiharjo-Lilley G. 1997. The Ecology of Nusa Tenggara and Maluku. Hong Kong: Periplus Editions.

Ostrom et al. 1994. Rules, Games, and Common-Pool Resources. The University of Michigan Press.

Safitri MA, Muhshi MA, Muhajir M, Shohibuddin M, Arizona Y, Sirait M, Nagara G, Andiko, Moniaga S, Berliani H, Widawati E, Mary SR, Galudra G, Suwito, Santosa A and Santoso H. 2011. Menuju kepastian dan keadilan tenurial: Pandangan kelompok masyarakat sipil Indonesia tentang prinsip, prasyarat dan langkah mereformasi kebijakan penguasaan tanah dan kawasan hutan di Indonesia (Road map to tenure security and justice: Civil society views in Indonesia on principle, condition and step of forest and land tenure policy reform). Jakarta, Indonesia.

Santoso H. 2003. Forest area rationalization in Indonesia: A study on the forest resource condition and policy reform. SEA Regional Office: World Agroforestry Center (ICRAF).
Sasaoka M and Laumonier Y. 2012. Suitability of local resource management practices based on supernatural enforcement mechanisms in the local social-cultural context. Ecology and Society 17(4): 6. http://dx.doi.org/10.5751/ES-05124-170406 [consulted the 20.09.2013]

Sikor T, Stahl J, Enters T, Ribot JC, Singh S, Sunderlin WD and Wollenberg L. 2010. REDD-plus, forest people's rights and nested climate governance. Global Environmental Change 20(3):423-25.

Sirait MT, 2009. Indigenous peoples and oil palm plantation expansion in West Kalimantan, Indonesia. The Hague: Amsterdam University Law Faculty and Cordaid.

Sist P, Dykstra D and Fimbel R. 1998. Reducedimpact logging guidelines for lowland and hill dipterocarp forests in Indonesia. CIFOR Occasional Paper No. 15. Bogor, Indonesia: CIFOR.

Sodhi et al. 2004. Southeast Asian biodiversity: an impending disaster. ELSEVIER, Trends in Ecology and Evolution Vol.19 No.12.

Sodhi NS, Koh LP, Clements R, Wanger TC, Hill JK, Hamer KC, Clough Y, Tscharntke T, Posa MRC and Lee TM. 2010. Conserving Southeast Asian forest biodiversity in humanmodified landscapes. Biological Conservation 143:2375-84.

Tempo. 2013. Rubber production fails to meet demands. Accessed 17 September 2013. http://en.tempo.co/read/ news/2013/06/25/056491086/RubberProduction-Not-Meeting-Demands,

[TFF] The Tropical Forest Fondation. 2009. Accessed 15 September 2013. http://www. tropicalforestfoundation.org/get-verified/ reduced-impact-logging.

Thompson GD and Wilson PN. 1994. Common property as an institutional response to environmental variability. Contemporary Economic Policy 12(3):10-21.

[USAID] 2010. USAID country profile: Property rights and resource governance - Indonesia. UN International Agency for International Development. Accessed 25 August 2013. http:// usaidlandtenure.net/sites/default/files/countryprofiles/full-reports/USAID_Land_Tenure_ Indonesia_Profile_0.pdf

van der Poel HP and Schinkel RF. 1985. An Appraisal of Farming Systems in 6 Villages on Lombok and Sumbawa. Agricultural University. FONC Project communication. 
89 pages. Here is the reference of the book if needed: http://books.google.fr/books/about/ An_Appraisal_of_Farming_Systems_in_6_Vil. html?id=L879tgAACAAJ\&redir_esc=yca

Vidal E. 2011. Manejo florestal com exploração de impacto reduzido $M F-E I R(R I L)$. Piracicaba, USP.

White A. 2011. Cash alone will not slow forest carbon emissions. Nature News 471:267

Wilkinson S. 2004. Focus groups: A feminist method. In Hesse-Biber SN and Yaiser ML, eds. Feminist Perspectives on Social Research. New York: Oxford University Press. 271-95.

Winoto J. 2009. Taking land policy and administration in Indonesia to the next stage and national land agency's strategic plan. Workshop in International Federation of Surveyors' Forum. Washington, DC.

Wollenberg E, Campbell B, Dounias E, Gunarso P, Moeliono M and Sheil D. 2009. Interactive land-use planning in Indonesian rain-forest landscapes: Reconnecting plans to practice. Ecology and Society 14(1):35.

Yasmi Y. 2007. Institutionalization of conflict capability in the management of natural resources: Theoretical perspectives and empirical experience in Indonesia. [PhD Thesis] The Netherlands: Wageningen University.

Yuliani L, Indriatmoko Y, Salim A, Farid IZ, Muhajir M, Prasetyo LB and Heri V. 2010. Biofuel policies and their impact on local people and biodiversity: A case study from Danau Sentarum. Borneo Research Bulletin 41:109-44.

Zerner C. 1994. Through a green lens: The construction of customary environmental law and community in Indonesia's Maluku Islands. Law and Society Review 28(5). Symposium: Community and Identity in Sociolegal Studies (1994), pp. 1079-1122. 


\title{
Appendix 1. Questionnaire for FGD (focus-group discussions)
}

\author{
Date \\ Locality \\ Group characteristics : \\ (gender and age) \\ Participants \\ Duration
}

\section{About participants}

1.1 Native from Waraka? Yes / No - Asli Anda?

1.2 Occupation/pekerjaan:

1.3 a. Do you own or rent any land? If owned, how did you get it (heritage, gift, ...)? Apakah Anda memiliki kebun? Cara mendapatkan kebun tersebut apa (Warisan ${ }^{*}$ Membuka hutan ${ }^{*}$ Membeli ${ }^{*}$ Menyewa?).

b. Where is it located (distance and time to get there from your house/from Waraka)? Seluas apa tanah yang Anda miliki (sampai di mana) dan bagaimana Anda mengelola tanah-tanah ini (menjual atau memberikan, membeli, mengalokasikan...).

\begin{tabular}{|l|l|l|l|l|l|l|}
\hline $\begin{array}{l}\text { Name } \\
\text { Nama }\end{array}$ & $\begin{array}{l}\text { Origin - } \\
\text { Asli }\end{array}$ & $\begin{array}{l}\text { Occupation - } \\
\text { Pekerjaan }\end{array}$ & $\begin{array}{l}\text { Land use, } \\
\text { if any- } \\
\text { Mimiliki } \\
\text { tanah? } \\
\text { Lahan apa? }\end{array}$ & Area - luas? & $\begin{array}{l}\text { How did you } \\
\text { get it - cara } \\
\text { mendapatkan? }\end{array}$ & $\begin{array}{l}\text { Location - Di mana } \\
\text { (how long to get there? } \\
\text { - Berapa lama sampai } \\
\text { sana) }\end{array}$ \\
\hline & & & & & \\
\hline & & & & & \\
\hline
\end{tabular}

\section{Natural resources exploitation}

FREE LISTING - Please list all kinds of land use that you have in Waraka. What do they produce? (highlight three main crops to consume and three to sell) Ada pengunaan lahan apa di Waraka? Menghasilkan apa? Berikan peringkat berdasarkan urutan kepentingan 3 jenis subsisten dan 3 jenis untuk dijual (warna kuning)? 


\begin{tabular}{|c|c|c|c|c|c|}
\hline $\begin{array}{l}\text { Land use } \\
\text { Penguna- } \\
\text { an lahan }\end{array}$ & $\begin{array}{l}\text { Production } \\
\text { (Bah. Indonesia } \\
\text { / local name) - } \\
\text { Menghasilkan }\end{array}$ & $\begin{array}{l}\text { Function } \\
\text { ((susbistence: } \\
\text { SUB or selling: } \\
\text { SEL?) - Untuk } \\
\text { dijual atau..? }\end{array}$ & $\begin{array}{l}\text { If sold, } \\
\text { where? } \\
\text { (Waraka, } \\
\text { Masohi...?) } \\
\text { Kalau dijual di } \\
\text { mana? }\end{array}$ & $\begin{array}{l}\text { Past evolution (last } 10 \text { years) } \\
\text { of needs and production in } \\
\text { Waraka? Can you explain } \\
\text { why?* Apakah kebutuhan } \\
\text { dan produksi meningkat atau } \\
\text { menurun dalam } 10 \text { tahun } \\
\text { terakhir? Alasan? }\end{array}$ & $\begin{array}{l}\text { Evolution - changes } \\
\text { "predicted" / wished? } \\
\text { (next } 10 \text { years or } \\
\text { Later?) Perhubahan? }\end{array}$ \\
\hline & & & & & \\
\hline & & & & & \\
\hline
\end{tabular}

\section{Scoring exercise:}

Cards with land uses listed above (col. 1): for the six main products highlighted in col. 2, please distribute the stones/nuts according to the importance of the land use corresponding. Please explain your choice.

\section{If no scoring exercice:}

Are traditional agroforestry systems important for you? Why?

Please give the advantages and disadvantages of each one, by order of importance, in terms of impacts:

\begin{tabular}{|l|l|l|l|}
\hline$n^{\circ}$ & Name & $(+)$ & $(-)$ \\
\hline & & & \\
\hline & & & \\
\hline
\end{tabular}

2.1 Do you work on pest and disease control? How did it evolve in the last years? Do you use any fertilizer? Apakan Anda mempraktikkan pengendalian hama dan penyakit? Bagaimana caranya? Memakai pupuk? Berevolusi (lalu bagaimana, nanti bagaimana)? Kalau produksi yang organik = tampa hama dan penyakit, Bapak/Ibu menarik?

2.2 a. What do you know about forests (what kind of forests do you have, do you often go there, for what?) - Apakah Anda tahu tentang condisi hutan?

b. How are they managed in Waraka (by clan/negeri/villagers, do you have any management plan (i.e. document))? Apa status hutan di Waraka, bagaimana hutan tersebut dikelola (oleh margalnegeril penduduk desa, apakah Anda memiliki rencana pengelolaan (dalam bentuk dokumen))?

\section{Companies}

3.1 Did you work for a private company? If yes, which one, how long for? Sudah bekerja dengan perusahaan swasta? Perusahaan apa dan sudah berapa lama?

3.2 Could you give the advantages and disadvantages of working in a company? Keuntungan dan kerugian kalau bekerja di perusahann?

a. What do you know about PTPN XIV, the cocoa company? Tahu apa tentang PTPN XIV, perusahaan coklat?

b. Would you like to work with them? Please explain why yes or no? Anda mau kerja di perusahaan itu? Kenapa?

Are there any logging company working in Waraka forest? Bagaimana dengan pembalakan? Ada perusahaan di Hutan yang permasuk Waraka? (Pembalakan liar / sah = legal?) Dampak sosial ekonomi dan lingkungan di masa lalu/sekarang/masa depan? 
What about commercial plantation? (Albisia?) Saya mendengar ada proyek penanaman Albisia... mendirikan perusahaan pulp dan kertas ...?

\section{Socioeconomic aspects and proximity with masohi. Aspek-aspek sosial ekonomi dan kedekatan dengan masohi}

4.1 What about transportation? When was this main road built? (1978)? Bagaimana dengan transportasi? Sejak kapan jalan utama ini dibangun?

4.2 Is your transport system satisfactory? Would you like to have other roads or improve your system? Apakah cukup, apakah Anda ingin memiliki jalan lain atau meningkatkan sistem aktual Anda?

4.3 What about the impacts of this road? (Better access to market? to education, hospital...? degradation of natural resources, water quality, ...)? Bagaimana dengan dampak dari jalan ini? (Akses yang lebih baik ke pasar? ke sekolah/pendidikan, rumah sakit...? degradasi sumber daya alam, kualitas air, ...)?

4.4 What about work opportunities related to this proximity to Masohi? Bagaimana dengan lapangan pekerjaan kalau Waraka dekat dengan Masohi?

4.5 Could you give the advantages and disadvantages of living close to Masohi? What could be different if Waraka was located far from Masohi? Keuntungan dan kerugian kalau tinggal di Masohi? Apakah yang akan berbeda seandainya Waraka terletak jauh dari Masohi?

4.6 Do the young generation prefer to go to the city and work there, or do they carry out traditional farming? (rice vs sago...?) Apakah generasi muda lebih suka pergi ke kota dan bekerja di sana, atau apakah mereka tetap bertani secara tradisional? (padi vs sagu...?)

4.7 Are they other impacts or influences from Masohi (positive/negative in terms of socioeconomic and environmental impacts)? Dampak atau pengaruh lain dari Masohi (positiflnegatif) dalam hal tidak hanya dampak sosial ekonomi namun juga dampak lingkungan?

\section{About the future}

What would you like for the future of your family and for Waraka, (what kind of evolution or development)? How do you think the situation will evolve, in terms of livelihoods, wages, employment, agriculture systems, forestry management, relationships with companies and other stakeholders ...? Do you have any fears? Tentang masa depan. Apa yang Anda inginkan tentang keluarga Anda dan Waraka di masa depan, (perhubahan atau perkembangan seperti apa)? Menurut Anda bagaimana situasi akan sungguh-sungguh berubah, terkait mata pencarian, kerja, sistem pertanian, pengelolaan kehutanan, hubungan dengan perusahaan dan stakeholder lain...? Apakah ada sesuatu yang ditakuti/dikhawatirkan? 


\section{Appendix 2. Full list of the semi-structured interviews used for the study}

\begin{tabular}{|c|c|c|c|}
\hline $\mathbf{N}^{\circ}$ & Function & Organization & Date and duration \\
\hline 1 & Social scientist & CIFOR & 25/04/2013, 1 hour \\
\hline 2 & Professor & $\begin{array}{l}\text { Pattimura University } \\
\text { of Ambon }\end{array}$ & 01/06/2011, 2 hours; 03/06/2011 (1 hour) \\
\hline 3 & raja & Waraka & $\begin{array}{l}02 / 06 / 2013,1 \text { hour + many other times less } \\
\text { officially }\end{array}$ \\
\hline 4 & Local representative (Sahulau) & Rainforest Alliance & 02/06/2013, $30 \mathrm{~min}$. \\
\hline 5 & Farmer & Waraka & $03 / 06 / 2013,1.5$ hours \\
\hline 6 & Farmer & Waraka & 03/06/2013, 1 hour \\
\hline 7 & Head of Adat & Waraka & 04/06/2013, 1 hour \\
\hline 8 & Forester and farmer & Waraka & $\begin{array}{l}\text { 05/06/2013, } 1 \text { hour + many other times less } \\
\text { officially (fieldwork assistant) }\end{array}$ \\
\hline 9 & Assistant director & PTPN XIV & 07/06/2013, 1.5 hours; $17 / 06 / 2013,1$ hour \\
\hline 10 & Director & PTPN XIV & 07/06/2013, 1.5 hours; $17 / 06 / 2013,45 \mathrm{~min}$. \\
\hline 11 & $\begin{array}{l}\text { Tuan tanah (in charge of adat } \\
\text { official declaration) }\end{array}$ & Waraka & 07/06/2013, 1 hour \\
\hline 12 & Assistant in logistics & PTPN XIV & 07/06/2013, $40 \mathrm{~min}$. \\
\hline 13 & Forester & Waraka & 07/06/2013, 45 min.; 03/08/2013, 1 hour \\
\hline 14 & Forest guard & Waraka & 09/08/2013, 1 hour \\
\hline 15 & Chief of forest guard & Waraka & 09/06/2013, 50 min. (+ many other times) \\
\hline 16 & Pastor & Waraka & $10 / 06 / 2013,45 \mathrm{~min}$. \\
\hline 17 & Supervisor of operations & APL & $\begin{array}{l}\text { 12/06/2013 and 31/07/2013, } 1 \text { hour (informal), on } \\
\text { site }\end{array}$ \\
\hline 18 & $\begin{array}{l}\text { Farmer, former employee PTPN } \\
\text { XIV }\end{array}$ & Moti (other village) & $28 / 06 / 2013,35 \mathrm{~min}$. \\
\hline 19 & Administrative assistant & PTPN XIV (Nari office) & $28 / 06 / 2013,40 \mathrm{~min}$. \\
\hline 20 & Farmer & Waraka II & $28 / 06 / 2013,45 \mathrm{~min}$. \\
\hline 21 & Farmer & Waraka II & $28 / 06 / 2013,45 \mathrm{~min}$. \\
\hline 22 & Farmer & Waraka & $29 / 06 / 2013,45 \mathrm{~min}$. \\
\hline 23 & Farmer & Waraka & $29 / 06 / 2013,50 \mathrm{~min}$. \\
\hline 24 & $\begin{array}{l}\text { Farmer (and Imam) - owner of } \\
\text { rubber plantation }\end{array}$ & Waraka & 04/07/2013, 1 hour + other times \\
\hline 25 & Farmer & Waraka & 05/07/2013, 1 hour \\
\hline 26 & Farmer & Waraka & 05/07/2013, 1,5 hour \\
\hline 27 & Farmer & Waraka & 05/07/2013, $45 \mathrm{~min}$. \\
\hline 28 & Professor & LIPI & 17/07/2013, several times \\
\hline 29 & $\begin{array}{l}\text { Owner of a sawmill and local } \\
\text { logging company (raja's brother) }\end{array}$ & Waraka & $19 / 07 / 2013,45 \mathrm{~min}$. \\
\hline 30 & $\begin{array}{l}\text { Owner of the logging company } \\
\text { APL }\end{array}$ & APL & 29/07/2013 (informal), in Waraka \\
\hline 31 & Head of Forest service Masohi & Ministry of Forestry & $20 / 10 / 2013$, by phone, $<30 \mathrm{~min}$. \\
\hline 32 & Member & $\begin{array}{l}\text { BAPPEDA } \\
\text { (ketanahan) }\end{array}$ & $21 / 10 / 2013$, by phone, $<30 \mathrm{~min}$. \\
\hline
\end{tabular}




\section{Appendix 3. Fact sheet: Waraka's home-gardens}

Some Waraka inhabitants have home gardens, i.e. small pieces of land near to the house planted with either annual or perennial crops and that they call kintal.

\section{Medicinal plants}

As part of a government program in the past years that focus on women's education (Pendidikan Kesejahteraan Keluarga or PKK), a group of villagers promoted the growth of medicinal plants through their project Apotek Hidup ("Living pharmacy") near the house. Many villagers used to plant ginger or alia (Zingiber officinale), turmeric (kunyit or Curcuma longa) and other species of Zingiberaceae.
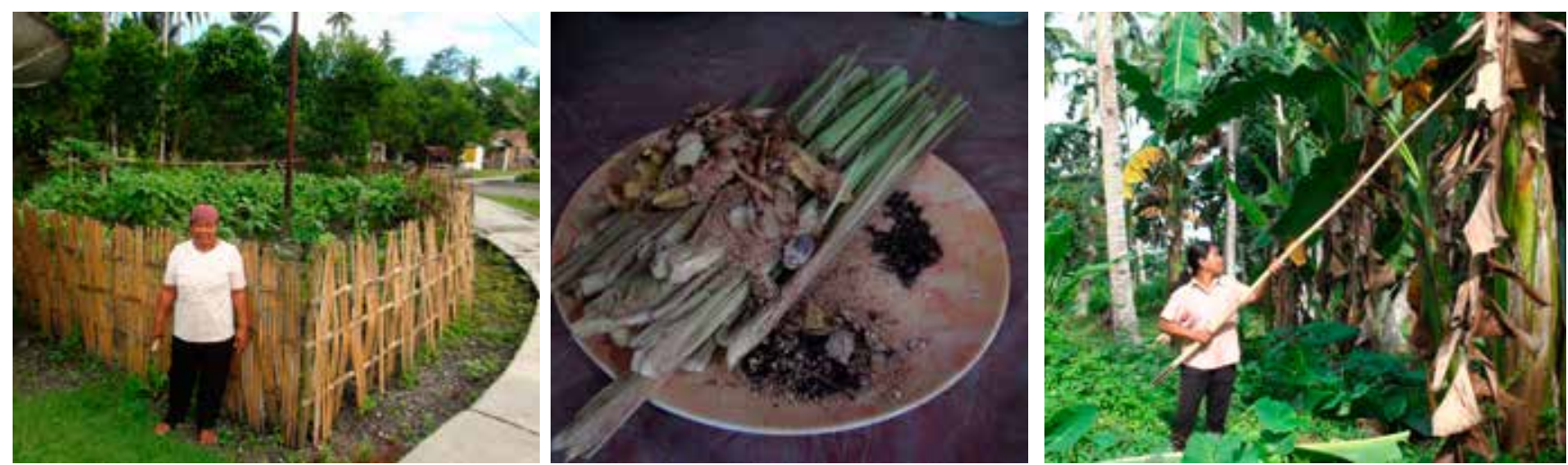

From left: Ibu Ida in front of her kintal, mix of medicinal plants (lemon grass, ginger, ...) and lbu Nona, collecting banana leaves

\section{Condiments, vegetables and fruits}

Villagers plant chilli (Capsisum annum and Capsisum frustescens), a daily-consumed condiment, and lemongrass or daun sire (Cymbopogon citratus D. Stapf) and pandan leaves (screwpine), called daun pandan (Pandanus amaryllifolius) in Indonesian. Where they have more space, villagers also grow vegetables. The most common is cassava (Manihot utilissima) or kasbi in the regional language of Maluku. They also plant terung or eggplant (Solanum melongena), jagung or corn (Zea mays), and roots such as sweet potatoes. It is common to consume leaves of kelor (Moringa oleifera) or petsai (Brasssica spp.). As fruits, they grow papaya (Carica papaya) and banana trees (Musa paradisica) with a large cultivated variety of banana raja, susu, abu-abu, 40 hari, meja (Ambon), nona, jarung or tanduk. They also have kedondong (Spondias dulcis), belimbing or starfruit (Averrhoa carambola), nangka or jackfruit (Artocarpus heterophyllus) and nangka belanda or soursop (Annona muricata). Last but not least, one or two coconut trees (Cocos nucifera) can also be found in home gardens. This list is not exhaustive.

\section{Importance of kintal}

Home gardens provide daily condiments, fruit and vegetables in addition to medicinal plants. In addition, they can also become a source of income. Even if they often share their production with neighbors, villagers also sell their surplus of bananas for example. In summary, these small patches of vegetables ideally complement their food crops field production. 


\section{Appendix 4. Fact sheet: Waraka's food crop fields}

Since dwellers go farming almost every day, food crop fields are ideally located close to the village (up to $3 \mathrm{~km}$ distance from the village). In Waraka area, these cultivated lands are found in the plains, on the south of the main road, bounded by the coconut and cocoa plantations of the PTPN XIV company on the west side and the River Pia on the east. Cultivation can also happen on the hills above the road, in the middle of mixed forest gardens or in agroforests that belong to Waraka inhabitants.

\section{Composition}

Waraka farmers mainly produce annual crops (tanaman palawija) such as cassava (Manihot esculenta) and yam (Dioscorea sp.), other kinds of tubers (ubi-ubian), chilii (Capsicum annum and Capsicum frustescens) and vegetables such as eggplant (Solanum melongena) and tomatoes (Lycopersicon esculentum).

\section{Importance of food crop fields}

As they constitute their major source of food, most villagers mention the importance of their food crop field. This kind of agriculture is also a regular, frequent and, compared to tree plantations, much faster source of cash income.

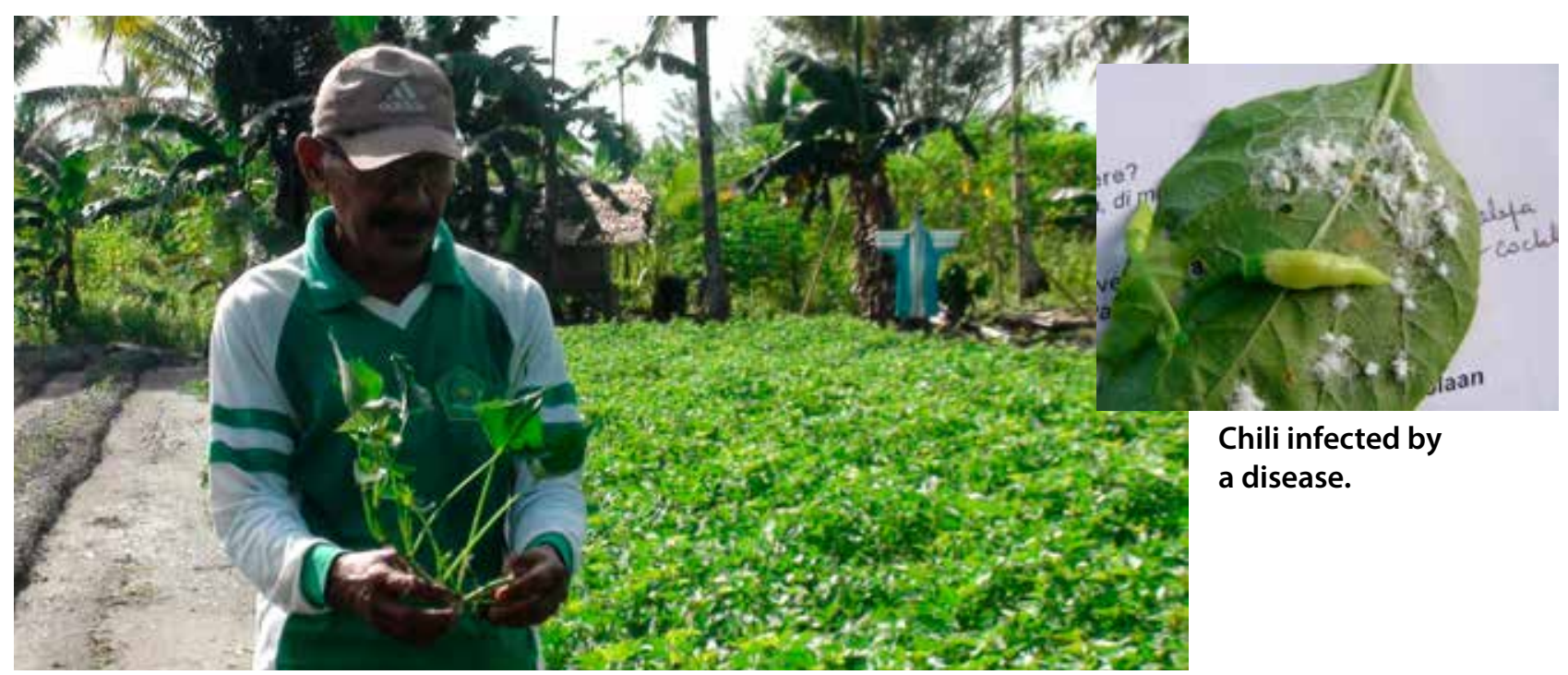

Pak Hatib in his food crop field.

\section{The land sharing: A win-win process}

Sometimes, land is managed by farmers who come from other villages such as Nari. The ousider occupies the place with the agreement of the owner. This land sharing is a win-win process. The help of the outsiders to keep the land clean is useful as the fields located in the hills are far from Waraka. 


\section{Appendix 5. Non-exhaustive list of vegetables that can be found in Waraka farmers' food crop fields}

\begin{tabular}{|c|c|c|c|c|}
\hline English name & $\begin{array}{l}\text { Local name } \\
\text { Indonesian/Wemale }\end{array}$ & Latin name & Production & Main uses \\
\hline Coconut palm & Pohon kelapa & Cocos nucifera & $\begin{array}{l}\text { Fruits, } \\
\text { fronds }\end{array}$ & $\begin{array}{l}\text { Food (fruits+oil), cash income, } \\
\text { medicine, construction (e.g. bridge), } \\
\text { cooking (packaging), frewood (from } \\
\text { fruits) }\end{array}$ \\
\hline Banana tree & Pohon pisang & Musa sp. & Fruit & Food, cooking, cash income, etc. \\
\hline Nutmeg tree & Pohon pala & Myristica fragrans & Fruit & Cash income, self-consumption \\
\hline Sugar palm & Aren/enau & Arenga pinnata & $\begin{array}{l}\text { Sap, } \\
\text { fruit, } \\
\text { fronds }\end{array}$ & Sopi , sugar, brooms, food \\
\hline Cocoa tree & coklat & Theobroma cacao & fruit & Cash income \\
\hline Langsium & duku/langsat & $\begin{array}{l}\text { Lansium } \\
\text { domesticum }\end{array}$ & $\begin{array}{l}\text { Fruit, } \\
\text { Wood (?) }\end{array}$ & Cash income, self-consumption \\
\hline durian & durian & Durio zibethinus & $\begin{array}{l}\text { Fruit, } \\
\text { wood }\end{array}$ & Cash income, self-consumption \\
\hline rambutan & rambutan & $\begin{array}{l}\text { Nephelium } \\
\text { lappaceum }\end{array}$ & $\begin{array}{l}\text { Fruit, } \\
\text { wood }\end{array}$ & Cash income, self-consumption \\
\hline Orange/lemon & jeruk & Citrus sp. & $\begin{array}{l}\text { Fruit, } \\
\text { leaves }\end{array}$ & Cash income, self-consumption \\
\hline Sago palm & sago & Metroxylon sagu & $\begin{array}{l}\text { Fruit, } \\
\text { Fronds, bark }\end{array}$ & $\begin{array}{l}\text { Food, cash income, construction } \\
\text { (roof made of leaves), packaging for } \\
\text { cooking, firewood }\end{array}$ \\
\hline guava & Jambu rutung & Psidium guajava & fruit & Food \\
\hline Jackfruit tree & Nangka & $\begin{array}{l}\text { Artocarpus } \\
\text { heterophyllus }\end{array}$ & & Food \\
\hline Bamboo & bambu & Bamboo sp. & "Wood" & Construction, cooking, food \\
\hline- & $\begin{array}{l}\text { Karta peca / gatal } \\
\text { babulu }\end{array}$ & & wood & Construction \\
\hline Lenggua & lenggua & Pterocarpus indicus & Wood & Construction \\
\hline- & $\begin{array}{l}\text { Gomu, role (meme } \\
\text { genre) }\end{array}$ & & Wood & Construction \\
\hline Pulaka & Pulaka & $\begin{array}{l}\text { Octomeles } \\
\text { moluccana }\end{array}$ & Wood & Construction \\
\hline- & Pule & $\begin{array}{l}\text { Alstonia scholaris } \\
\text { R. Br. }\end{array}$ & Wood & Construction \\
\hline Kinar & Kinar & $\begin{array}{l}\text { Kleinhovia hospita } \\
\text { Linn. }\end{array}$ & Wood & Construction \\
\hline- & Kuini & Mangifera odorata & Fruit & \\
\hline Kenari & Kenari & Canarium Oleusum & $\begin{array}{l}\text { Wood, } \\
\text { Seeds }\end{array}$ & Construction, consumption \\
\hline- & Saong & $?$ & Fruit & $\begin{array}{l}\text { Medicinal plant (one bottle costs } \\
\text { IDR 500,000 famous in Papua) }\end{array}$ \\
\hline
\end{tabular}




\section{Appendix 6. Coconut and cocoa production of Waraka's community}

"The multipurpose coconut is a boon for long-distance, tropical islands travellers, providing a ready source of food, drink and shelter". (van der Poel and Schinkel 1985)

To define private coconut or cocoa plantations, Waraka inhabitants use the terms dusun (dusun kelapa for coconut plantation and dusun coklat for cocoa plantation) or kebun (kebun kelapa or kebun coklat). However, a plantation of cocoa trees under coconut palms will be called dusun or kebun coklat, in relation to the cocoa which gives the specificity to the area (coconuts are found almost everywhere).

\section{The coconut production, main activity of harvesting}

Coconut harvesting is carried out every 3 months, whereas cocoa, clove and nutmeg have only one peak of production per year. Almost all parts of these palms are used by villagers. They plait leaves to make bowls and bake suami (a kind of bread from cassava flour) and wrappings to cook ketupa for instance (rice with coconut milk). They also prepare coconut oil and coconut milk for daily cooking, medicinal oil (from the young coconuts), smashed flesh to eat, etc. The water of the young coconut can also be consumed at any time. Also, the wood is used for different kinds of construction such as little bridges.

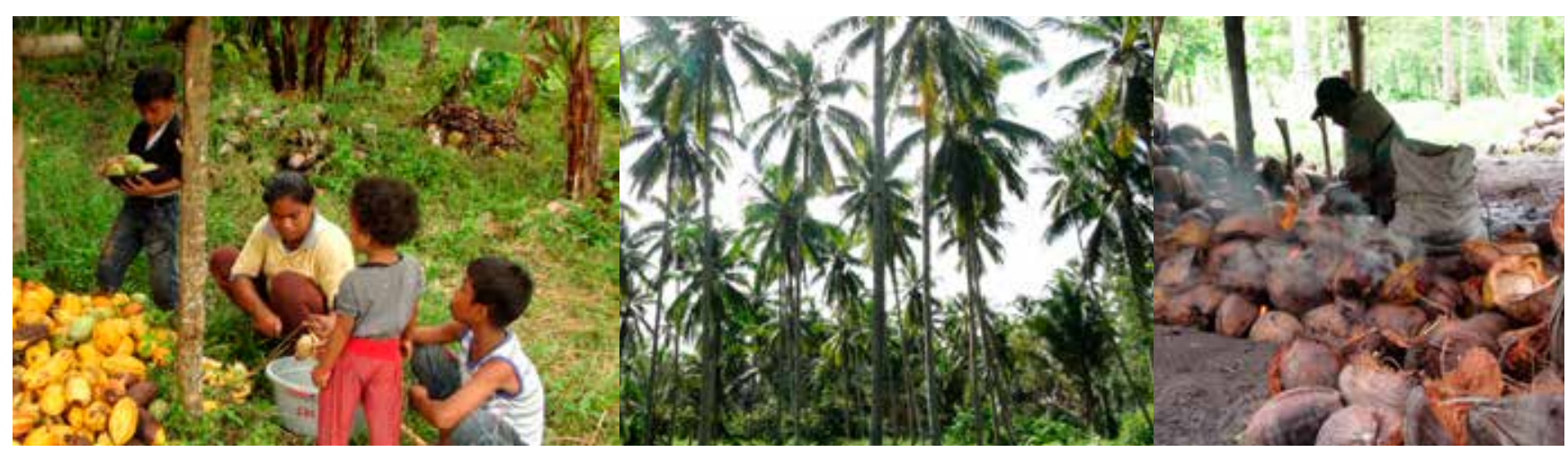

From the left: A family harvesting cocoa fruits, a plantation of coconut trees and a farmer processing copra (coconut)

\section{A cocoa of poor quality}

According to the villagers, in the past the quality of their cocoa production was excellent. Then the PTPN XIV company entered the territory and after a few years pests started to invade plantations. Many locals attribute this to the excessive use and misuse of chemicals and especially fertilizers, by the PTPN XIV, which may have attracted the cocoa moss (petoktora, kunng/PPK, Nilaparvata lugens). Today, all the plantations of cocoa in Teluk Elpaputih regency are infected by the pest. Hence, the quality of the commercial or private plantations is quite poor. $A$ few years ago, the company organized some workshops on mechanical treatments and chemical use to teach employees how to improve the management of their plantations. The mechanical cleaning, which mainly consists of pruning the trees and eliminating the contaminated fruits, proved to be efficient, but it was not applied by the whole community and was finally abandoned. Thus, in Waraka territory cocoa plantations are of low quality. 


\section{Appendix 7. The remaining production of rubber in Waraka}

In 1994-1995, the government provided Waraka villagers with 600 to 1000 seedling of rubber trees per hectare and per person. Anyone who had interest in managing a rubber plantation was able to start one. However, only two people finally conducted the project. One has since died, while the second still harvests his trees. The still active area is not under a system of single-crop farming: (Theobroma cacao) are also present under the rubber trees (Hevea brasiliensis), and it covers a total area of about 1 ha. The plantation is located above PTPN XIV's coconut plantations, at the top of Solemanata (Kelapa II), the village of the company's employees. It is called kebun, perkebunan or dusun karet.
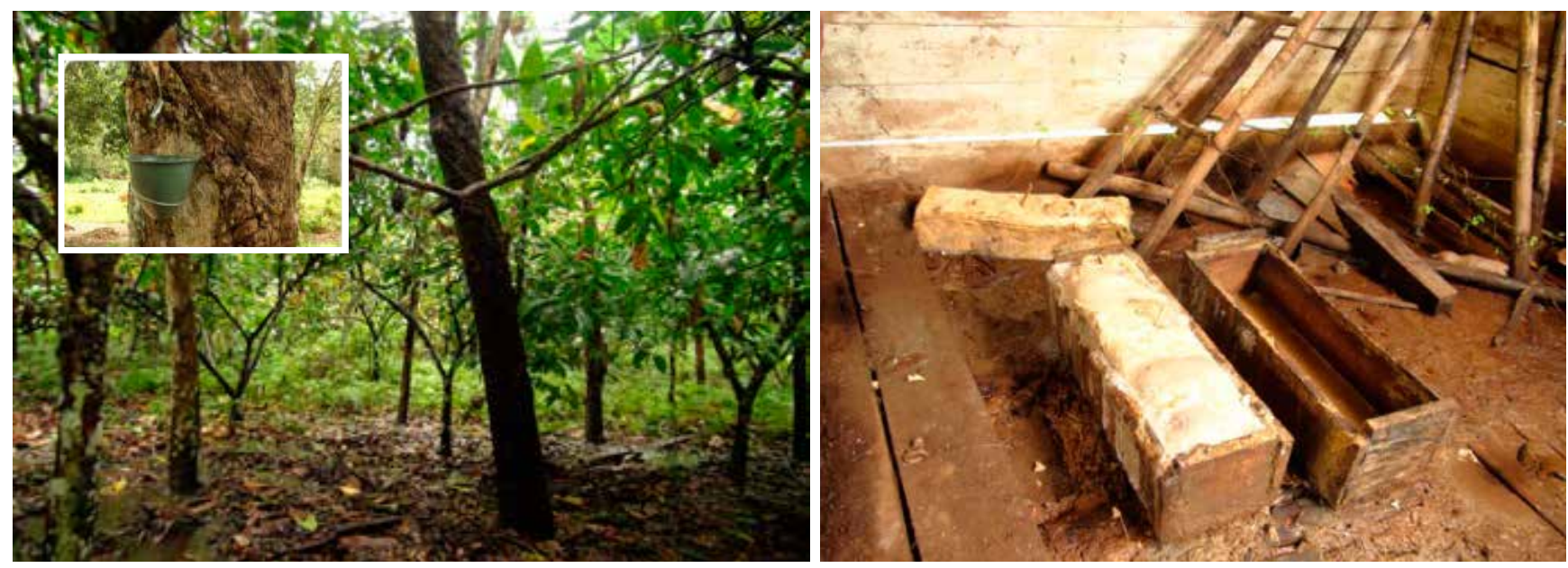

Mixed cocoa and rubber plantation and detail on rubber harvesting cup (left) and lump/dry rubber (right)

\section{A production of good economic interest}

Pak Hatib, the remaining owner of the rubber plantation explains:

Rubber plantations are very easy to manage, and you can get a very good salary with its production if you take care of the area. Today we sell it $9500 \mathrm{rp} / \mathrm{kg}$, so one person that harvests only $10 \mathrm{~kg}$ per day on an area of half a hectare will get an income of at least 1.9 million per month. And with a larger area and good management you can easily gain more than 3 million per month.

Rubber plantations could be good economically. Nevertheless, to date, the majority of Waraka inhabitants do not wish to plant rubber; they may not have the skills to do so and they prefer other kind of work. Some villagers said that they would rather go farming on their food crop fields because they do not need to be so regular and can choose their hours of work (in rubber plantations the harvest has to start at 5 a.m.). 


\section{Appendix 8. Mixed tree gardens of Waraka: Dusun in the lowlands}

\section{General surface and location}

Mixed tree gardens are spread out all over the area managed by the community (from the coast to the main road), alternating with coconut and cocoa plantations, dusun sago, food crop fields, open areas and secondary regrowth forests. They have an area of 1.5-2 ha up to 10 ha, according to the influence of its owner's family when they settled in Waraka and to the management of the land from generation to generation (division or dati, sale, etc.).
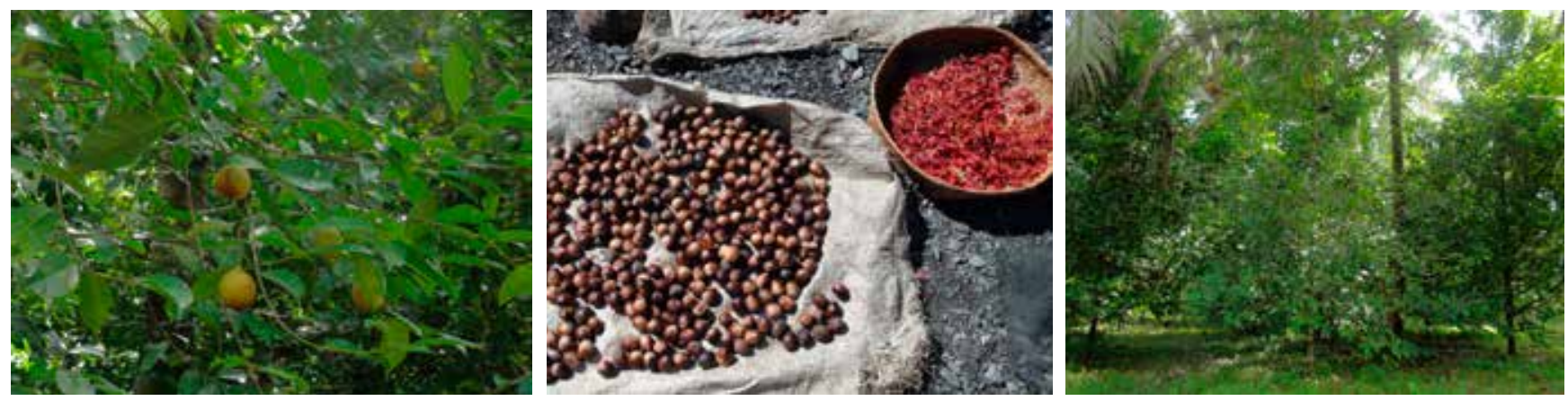

Left: nutmeg fruits, middle: nutmeg fruits and nutmeg flowers drying, left: nutmeg tree in a dusun

\section{Nutmeg production}

Clove and nutmeg were the first commercial tree crops in Nusa Tenggarah and Maluku, both originating in Maluku (Monk et al. 1997). In Waraka's lowlands, 30 years ago the first or second most planted species was nutmeg (Myristica fragrans). The dusun was then called dusun pala ("dusun nutmeg"), and this crop was the main source of income of this plantation. Today there is no plantation with a so clear dominance or codominance of nutmeg trees and the plantations, even if containing a few Myristica fragrans, are denominated dusun kelapa ("dusun coconut"). According to a socioeconomic survey conducted by Liswanti et al. (2013) in Waraka, today nutmeg production provides an average income of IDR 924,000 per year and per household (see Table 3), which means that it is the fourth major source of cash income from perennial crops after coconut, clove and cocoa. One of the main argument given by locals to plant more coconut and less nutmeg trees than the previous generation is that coconut crops can be harvested three times a year while for nutmeg is only once a year.

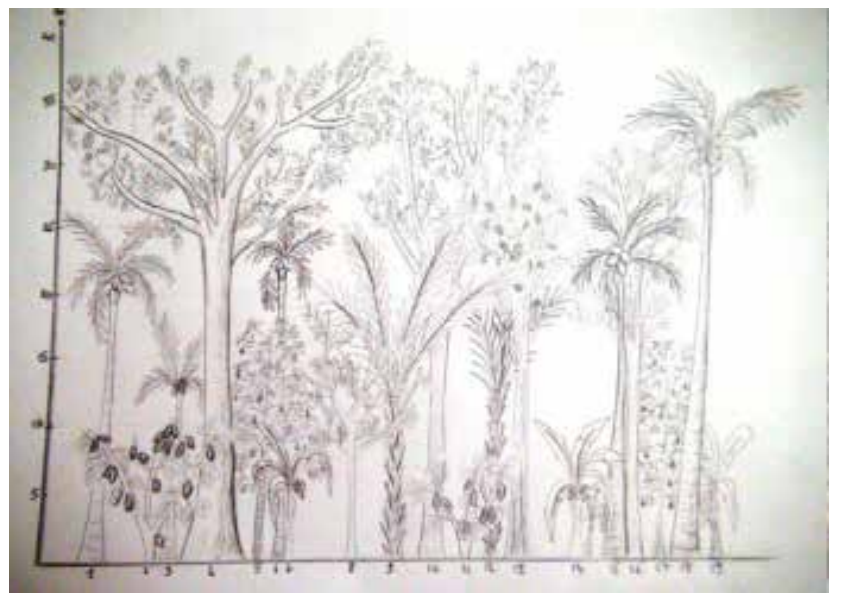

\section{Legend}

$1,3,6,15,18$ : coconut tree/kelapa (Cocos nucifera)

2, 11: cocoa tree/coklat (Theobroma cacao)

4: durian/durian (Durio zibethinus)

5: nutmeg tree/pala (Myristica fragrans)

7, 14, 19: banana tree/pohon pisang (Musa sp.)

8: Rambutan/rambutan (Nephelium lappaceum)

9, 12: Sugar palm/enau (Arenga pinnata)

13: Lansium/duku, langsat (Lansium domesticum)

16: Lenggua/lenggua (Pterocarpus indicus)

Sketch profile of a mixed forest garden. 


\section{Appendix 9. Non-exhaustive list of species found in the traditional mixed forest gardens of Waraka's community}

\begin{tabular}{lll}
\hline English name & $\begin{array}{l}\text { Local name in Bahasa Indonesia } \\
(+/ \text { - in Wemale if different) }\end{array}$ & Latin name \\
\hline Cassava & Singkong/ubi kayu (kasbi) & Manihot escukenta \\
\hline Eggplant/aubergine & Terung & Solanum melongena \\
\hline Water spinach & Kangkung merah/putih (air/darat) & Ipomoea aquatica or reptana \\
\hline Cabbage & Kol & Brassica oleracea var. capitata \\
\hline Curry leaves & Sawi Daging & Brassica juncea \\
\hline Summer turnip rape & Sawi Hijau & Brassica rapa var. parachinensis \\
\hline Mustard greens & Pisai putih =pahaayang/pisai pahit (endemic species & Brassica sp. \\
\hline Tomato & Maluku) & \\
\hline Sweet potato & Tomat & Lycopersicon esculentum \\
\hline Taro & Ubijalar & Ipomoea batatas L. \\
\hline Spinach & Kladi. Kladi kepala (kelapa?) =(kladi kolang) & Colocasia esculenta \\
\hline Beans & Bayam cabut merah/putih & Amaranthus spp. \\
\hline Gnetum, joint fir & kacang hijau, kacang panjang & Phaseolus lunatus \\
\hline Squash & Belinjo (danemon) & Gnetum gnemon \\
\hline Chayotes & Labu & Cucurbita moschata \\
\hline String bean & Labu siam & Sechium edule \\
\hline Cucumber & Buncis (boncis) & Phaseolus vulgaris \\
\hline Angled luffa & Ketimun & Cucumis sativus \\
\hline Peanuts & Gambas & Luffa acutangula \\
\hline Yam & Kacang tanah & Arachis hypogaea \\
\hline & Ubi rambat & Dioscorea alata \\
\hline
\end{tabular}




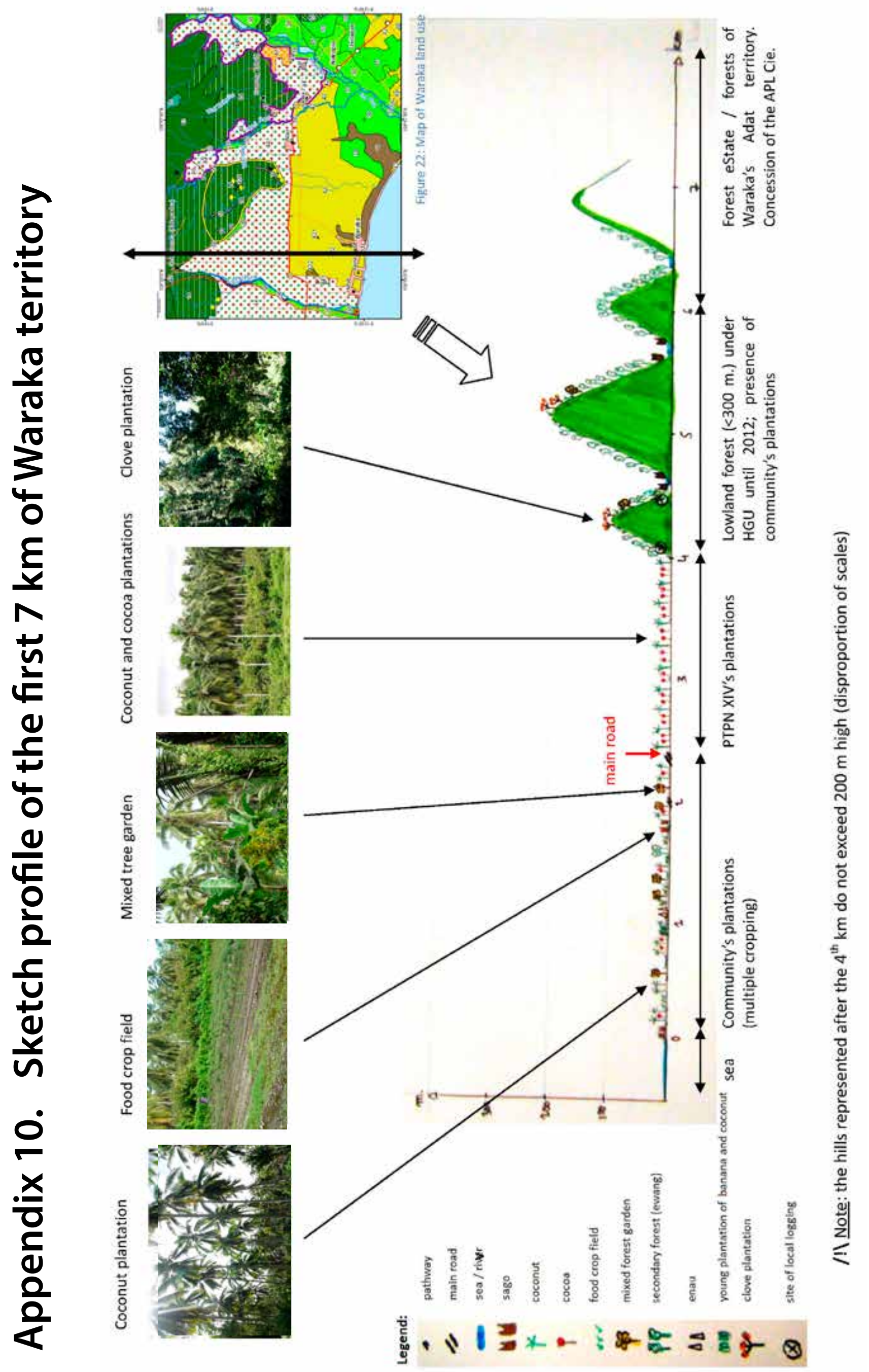




\title{
Appendix 11. Sago (Metroxylon sagu) production in Waraka
}

\begin{abstract}
"We, villagers of Waraka, are like sago trees: Dark outside, but white inside." Pak Maku, farmer of Waraka.

The sago palm (Metroxylon sagu), liki or liki patai in Wemale language, is the main staple food of Waraka inhabitants. For many years, farmers have planted this palm close to the village, in convenient areas rather than being totally dependant on wild sago. Today, it can be found all along riparian zones or by plot, still around rivers, on hydromorphic soils. Sago swamps are numerous, alterning with food crops fields, other dusuns and patches of secondary regrowth forest.
\end{abstract}

\section{Production}

In Maluku, one palm provides about $200 \mathrm{~kg}$ of wet starch flour and can feed a family of four to five people for 10 weeks, or one person for nearly a year (Monk et al.1997). Its cultivation and production are highly labor efficient. They are mature in 15 years and then they can be harvested. In Waraka it takes 2-3 days to process a few tree with machines, and it took 2-3 weeks in the past when it was all manual. In all the regency of Teluk Elpaputih, there is only one commerical sago factory, located in Tananahu. In Waraka territory all the production is conducted by individuals, but they can decide to sell their palms to the commercial factory which usually pays IDR 50 to 75,000 per standing tree. They may pay more if the seller knows more about prices, as occurred with the raja who sold 40 trees for IDR 100,000 per unit. One sago tree can provide about 20-25 tumang (leaf container for sago meal) which are sold at IDR 30,000 each. That is equivalent to at least IDR 600,000 per tree.
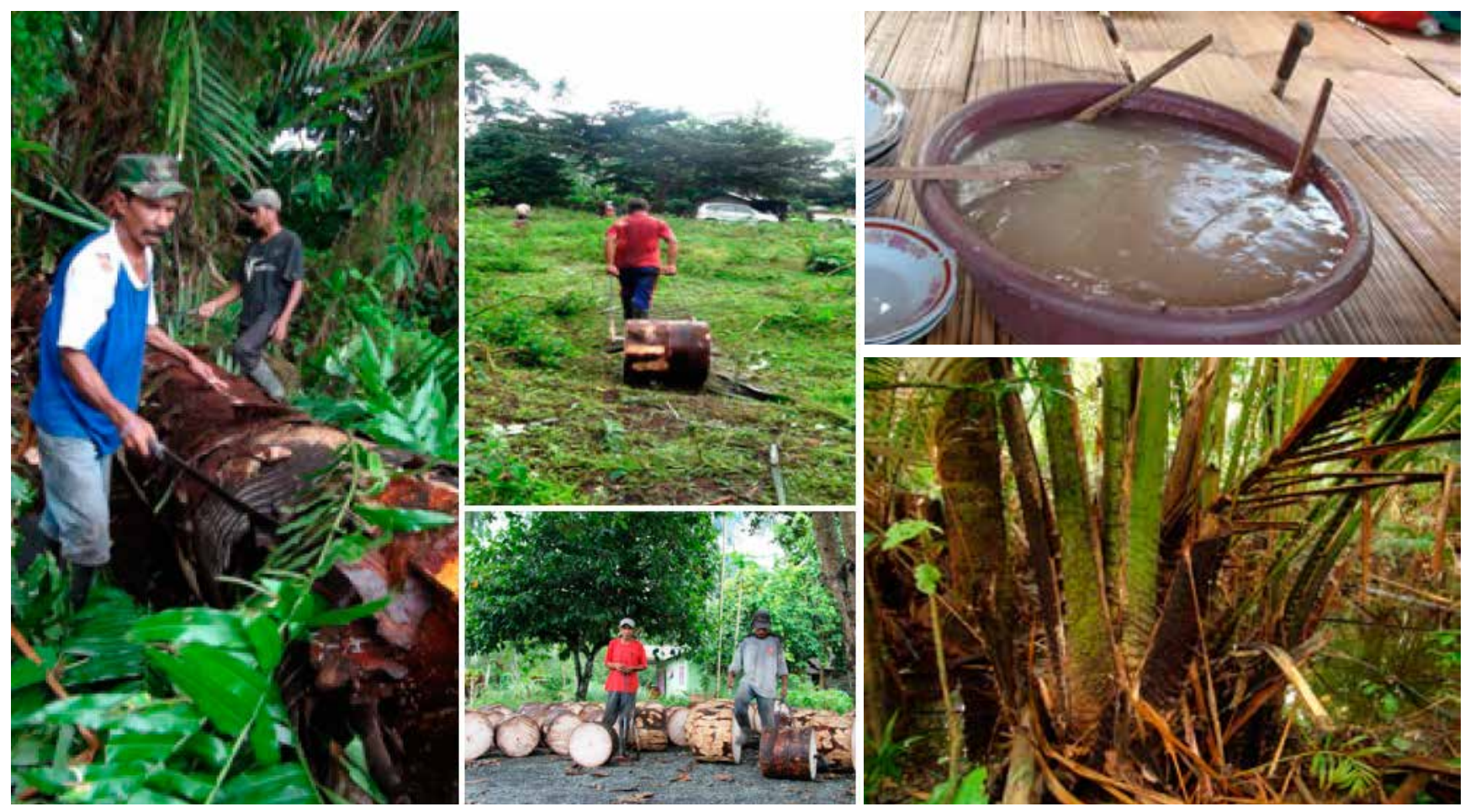

Exploitation of sago (left and center), sago palm (right bottom) and papeda, a kind of sticky sago paste (right top) 


\section{Appendix 12. Albisia priangan Lestari (APL): Private logging company}

\section{Relationship with local communities}

The company started prospecting in the region years ago to assess the land-tenure situation and avoid eventual conflicts with local communities. Before they started logging operations, the representatives of adat in Waraka organized a ritual with the company to "ask ancestors the permission to log their forest" (apapu).

\section{Environmental impact}

The company does not have a management plan. No attention is paid to the preservation of water quality or to the conservation of the local fauna and flora. There is no road planning. The soil is composed of metamorphic rocks; landslides and erosion are common on the steep slopes of the site. During the rainy season, tractors and trucks use the river as their main road to go from the log pond on the beach to the base camp in the mountain (15 km from the log pond). Conditions related to the reforestation remain unclear. According to the company, they may replant trees available in the forest through the use of the national sylviculture and production system (Tebang Pilih Tanam Indonesia or TPTI): Matoa (Pometia pinnata), Merenti (Shorea sp.), Pulaka (Octomeles moluccana), Samama (Anthocephalus macrophyllus). However, according to the raja, they may focus on the creation of an industrial plantation ( $\mathrm{HTI}$ ) of Paraserianthes falcataria (sengon in Bahasa Indonesia or salawaku in Maluku dialect) that the community planted with seedlings imported by the company from Sulawesi or Java.

\section{Employment and work conditions}

Albisia Priangan Lestari employs 5-12 chainsaw operators and 5-12 helpers. Workers come from Sulawesi, Sumatra, Java and Malaysia. From Waraka, there are two permanent staff (guards) and up to 10 workers who come for survey operations. Workers are payed IDR 1.2 to 6 million per month or IDR 85,000 to 100,000 per day. This is better than at the PTPN XIV company, but the work is described by Waraka inhabitants a harder and the employees must live at the base camp for the whole month or, at least, for the whole week, which makes villagers particularly reluctant to do this kind of job. In July 2013, the company employed some people to remove the bark of the logs for a salary of IDR 1500 per $\mathrm{m}^{3}$ of wood. A team of six people can process up to 60 logs of 2 or 3 to $4.5 \mathrm{~m}^{3}$ per day. That means an average income of IDR 30,000 to 45,000 per day (low salary). There is no safety equipment at the log pond, on the beach or at the base camps in the mountain, and log ponds are poorly organized (no proper office and logistical problems).
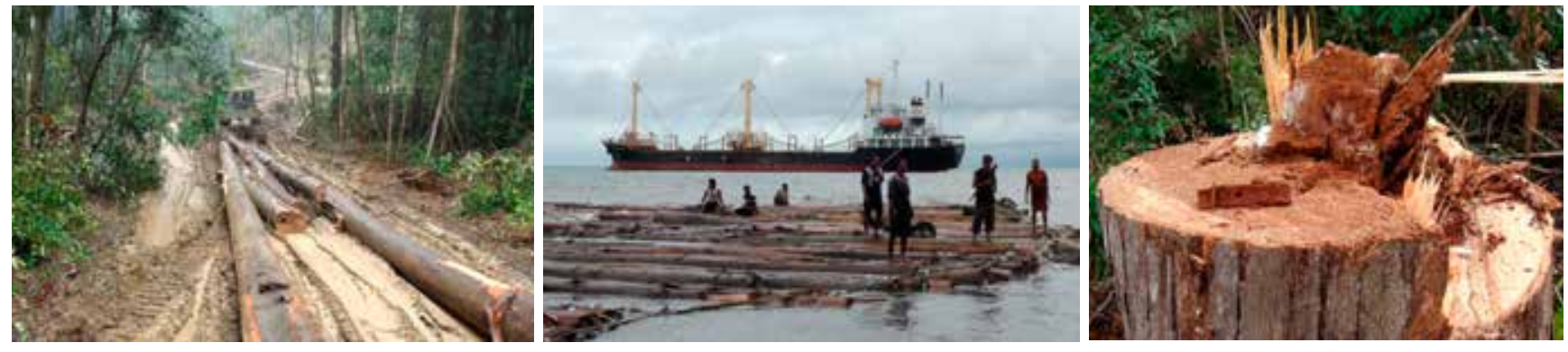

Skidder (left), wood loading by seaway (center) and dewtail of a log recently cut (right) 


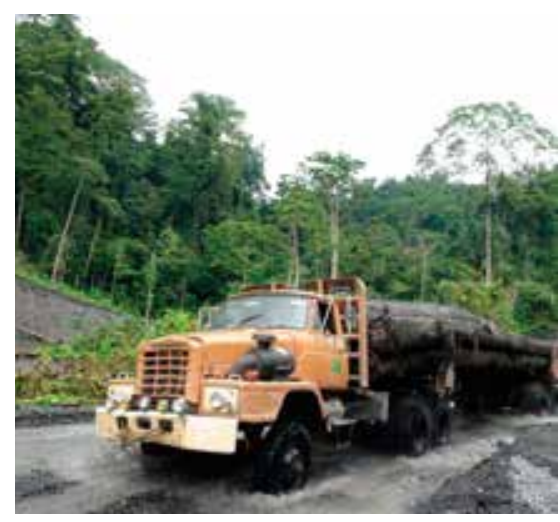

\section{Calendar of activities}

- 2007: Prospecting, first study of the territory (verification of the landtenure situation)

- April 2011: Opening of the log pond

- December 2012: Opening of the road to the future logging site (according to villagers)

- May 2013: Opening of the main access to a first base camp

- June 2013 : Logging activities started officially

- August 2013 : One boat with $816 \operatorname{logs}\left(2,956 \mathrm{~m}^{3}\right.$, average of $3 \mathrm{~m}^{3}$ per log) already left

- October 2013: Three boats with $3700 \mathrm{~m}^{3}$ of wood left the beach of Waraka. No written agreement yet between the company and the community or the raja. 


\section{Appendix 13. The PTP Nusantara XIV: A state- owned cocoa, coconut and rubber company}

\section{Employment}

Employees are under permanent contract or Tenaga Bulanan Tetap/TBT or Tenaga harian Tetap/THT, named "organik" employees. This group of TBT employees get healthcare for their family and the company bears the cost of their children's education. Nevertheless, from Waraka there are no more than 3 employees that benefit from these work conditions. The others are under a 1 year (KKWT, Karyawan Kontrak antara Waktu) or a daily (THL, Tenaga Harian Lepas) contract. KKWT and THL employees are paid according to the system of borongan: they get a salary based on the employee's production. One of the main concerns of Waraka's community is that villagers would like to be paid on a daily basis rather than based on their production.

Today the number of employees is 1634 , with $400-500$ THL employees employed during cocoa production peaks. According to numerous interviews with farmers, the number of THL employees at PTPN XIV is even higher. Already 90-100 people work in rubber nurseries or plantations and a great amount of workers are not legally registered. This non-official employment is described as "one of the numerous bad practices of the company". In Waraka, 30 villagers work at the PTPN XIV: 20 for the harvest of cocoa, 10 as guards.

\section{Salaries}

Farmers are payed IDR 400 per kg of coconut and IDR 600 per $\mathrm{kg}$ of fresh cocoa, which means an average income of IDR 32,000 per day (US\$2.82) for coconut (for about $80 \mathrm{~kg}$ per day) and IDR 25,000 per day (US\$2.21) for cocoa (around $40 \mathrm{~kg}$ /day harvested every day). Since July 2013, farmers get a monthly salary based on an amount of IDR 51,000 per day (US\$4.50 USD) for a 7-hour day.

Related to rubber production, workers are payed IDR 3000 per kg of lump (latex already transformed), so they have to produce $16.5 \mathrm{~kg}$ of lump to obtain the minimum salary of IDR 51,000 per day (IDR 1,275,000 per month). According to the company, if they work hard they can earn up to IDR 2 million per month. Employees not in production (cleaners, guards, etc.) are payed on a daily basis (IDR 51,000 per day).

\section{Rubber plantations}

The PTPN XIV company planted a total of 1486 ha, the majority being outside of the administrative territory of Waraka. They started in 1984 and so today most of the trees are declining. They are planted in $2.5 \mathrm{~m} \times 8 \mathrm{~m}(500 \mathrm{trees}$ per hectare), but with natural decline, the density is now reaching 146 trees per hectare (Eldeuw site). PTPN XIV mainly uses Gete clones, I.R. clones and PB-260 clones. They start to harvest trees when they are 6 years old and have a diameter of $45 \mathrm{~cm}$. Employees collect the latex, turning on two plots in 2 days or 3 plots in three days if the plantation is productive enough. They have two rubber nurseries located between the Nari River and Pia River in the 616-ha zone that the community of Waraka wants to get back. There are 6000 seedlings ready to plant in October of this year. The objective is to cover a first area of 50 ha, probably in this same zone of 616 ha where new rubber plantations have already been established in recent years. 

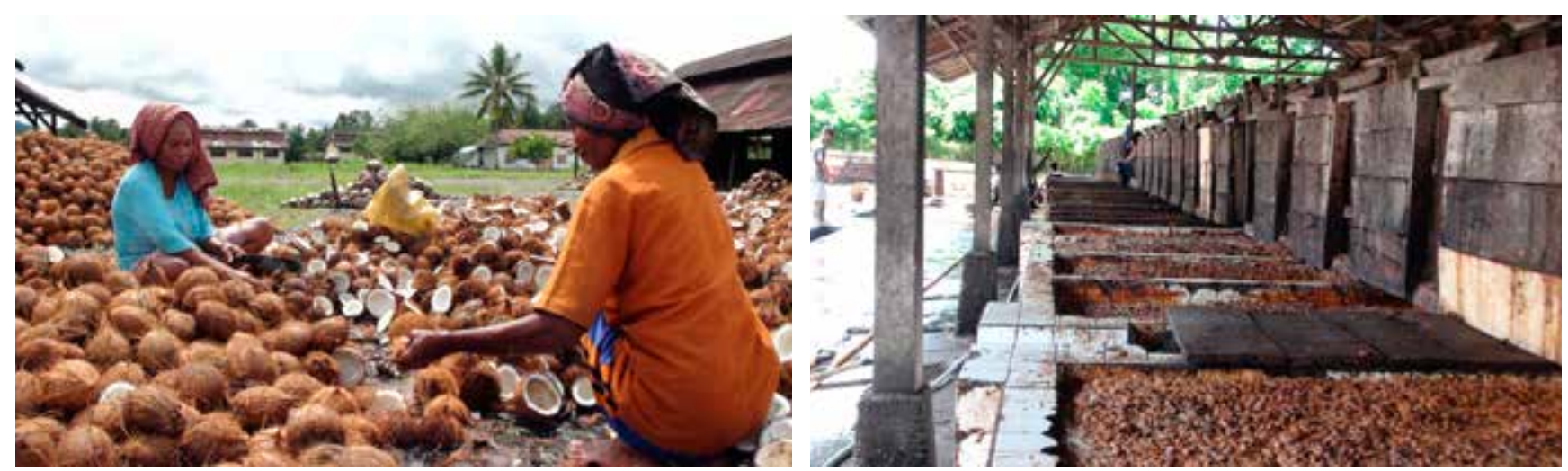

Processing coconut (left) and cocoa (right) at the PTPN XIV. L. Ducos (2013). 

CIFOR Working Papers contain preliminary or advance research results on tropical forest issues that need to be published in a timely manner to inform and promote discussion. This content has been internally reviewed but has not undergone external peer review.

In Indonesia, natural resources are under pressure from both urban development and commercial exploitation. In Seram Island, Maluku, oil palm plantations are expanding in the north. In the south of the island, a State-owned cocoa company and a private logging enterprise are exploiting the vast territory of Waraka, an ancestral village established on the coast. The set of customary laws and principles of this village, locally called adat, is still powerful and is the basis of the traditional land tenure and land-use systems. In order to promote the socioeconomical development of his community, the king or raja of Waraka interacts with both companies within a dual and uncertain legal framework. The methodology in this study is based on the institutional framework analysis developed by Ostrom (1994) and a preliminary literature review. It also encompasses qualitative interviews. The evolution of the land tenure and land-use systems of Waraka is related to the strength of adat's recognition and the ability of the raja to conduct deals with both companies. The study finally discusses the possibilities for all stakeholders to manage the land in a more sustainable way through the implementation of a tree-nursery program funded by credit carbons or the use of reduced impact logging practices.

This research was carried out as part of the European Union funded Collaborative Land Use Planning and Sustainable Institutional Arrangement project (CoLUPSIA). Run by CIRAD in partnership with CIFOR, TELAPAK and several local NGOs and Universities, the project aims to contribute to avoided environmental degradation and to strengthen land tenure and community right by collaboratively integrating all stakeholders' views in land use planning processes. The outputs revolve around the relationship between land use planning, land allocation and the provision and potential payment of ecosystem services. The project focuses on two regencies (kabupaten), Kapuas Hulu and Central Maluku in Indonesia. 